\title{
RELAÇÃO CUSTO-BENEFÍCIO DA IMPLANTAÇÃO DO SISTEMA DE ANÁLISE DE PERIGOS E PONTOS CRÍTICOS DE CONTROLE (APPCC) EM LATICÍNIO DO ESTADO DE SÃO PAULO
}

\section{SUELI CUSATO}

Dissertação de Mestrado apresentada à Comissão de Pós Graduação da Faculdade de Zootecnia e Engenharia de Alimentos da USP, como parte dos requisitos para a obtenção do Título de Mestre em Zootecnia, na área de Concentração: Qualidade e Produtividade Animal.

Orientador: Prof. Dr. Carlos Augusto Fernandes de Oliveira 


\section{RELAÇÃO CUSTO-BENEFÍCIO DA IMPLANTAÇÃO DO SISTEMA DE ANÁLISE DE PERIGOS E PONTOS CRÍTICOS DE CONTROLE (APPCC) EM LATICÍNIO DO ESTADO DE SÃO PAULO}

\section{SUELI CUSATO}

Dissertação de Mestrado apresentada à Comissão de Pós Graduação da Faculdade de Zootecnia e Engenharia de Alimentos da USP, como parte dos requisitos para a obtenção do Título de Mestre em Zootecnia, na área de Concentração: Qualidade e Produtividade Animal.

Orientador: Prof. Dr. Carlos Augusto Fernandes de Oliveira 


\section{FICHA CATALOGRÁFICA}

preparada pela

Biblioteca da Faculdade de Zootecnia e Engenharia de Alimentos da Universidade de São Paulo

\begin{tabular}{|l|} 
Cusato, Sueli \\
Relação custo benefício da implantação do sistema de análise \\
de perigos e pontos críticos de controle (APPCC) em laticínio do \\
Estado de São Paulo. / Sueli Cusato - Pirassununga, 2007. \\
$113 \mathrm{f}$. \\
Dissertação (Mestrado) -- Faculdade de Zootecnia e \\
Engenharia de Alimentos - Universidade de São Paulo. \\
Departamento de Engenharia de Alimentos \\
Área de Concentração: Qualidade e Produtividade Animal. \\
Orientador: Carlos Augusto Fernandes de Oliveira. \\
Unitermos: 1. APPCC 2. Custo-benefício 3. Iogurte \\
4. Laticínio. I. Título.
\end{tabular}


Há homens que lutam um dia, e são bons;

Há outros que lutam um ano, e são melhores;

Há aqueles que lutam muitos anos, e são muito bons;

Porém há os que lutam toda a vida

Esses são os imprescindíveis

Bertold Brecht

À todos aqueles que trabalham incansavelmente pela melhoria da qualidade do leite em todos os elos da cadeia produtiva 


\section{AGRADECIMENTOS}

Ao Professor Dr. Carlos Augusto Fernandes de Oliveira pela orientação e pelos ensinamentos transmitidos.

Ao Professor Dr. Augusto Hauber Gameiro pela participação nas etapas referentes aos custos e pelo auxílio nas análises dos resultados.

À Faculdade de Zootecnia e Engenharia de Alimentos da Universidade de São Paulo pela estrutura de ensino.

Aos amigos Marcelo e Marli Duarte por terem possibilitado a execução deste trabalho e pelo carinho com que me receberam.

Ao amigo e pesquisador Sergio Raposo de Medeiros pelas sugestões e correções, todas aceitas.

Às amigas Evelise Andreatta e Andréa L. dos Santos pela amizade, alegria e palavras de encorajamento.

Às eternas amigas Ângela, Marta e Mariza Raposo de Medeiros por estarem ao meu lado em todas as etapas deste trabalho.

Aos meus pais Nelson e Marlene pelo apoio e por estarem sempre presentes, apesar da distância.

Ao Alfredo Ramos Santos por compreender a minha ausência durante a execução deste trabalho.

Ao amigo e Zootecnista André Raposo de Medeiros, pelo companheirismo e amizade, desde sempre. 


\section{RESUMO}

CUSATO, S. Relação custo-benefício da implantação do sistema de análise de perigos e pontos críticos de controle (APPCC) em laticínio do Estado de São Paulo. 2007. 113 f. Dissertação (Mestrado) - Faculdade de Zootecnia e Engenharia de Alimentos, Universidade de São Paulo, Pirassununga, 2007.

Este estudo teve como objetivo avaliar a relação custo/benefício do sistema APPCC implantado na linha de produção de iogurte em uma indústria de laticínio em São Carlos, São Paulo de Agosto de 2006 a Agosto de 2007. Foi realizada a mensuração dos custos totais para elaboração e implantação do APPCC bem como a avaliação da qualidade microbiológica do produto acabado e do nível de perdas de embalagens durante o processamento, antes e após a implantação do sistema. Inicialmente foi realizada adequação aos programas pré-requisitos e treinamento dos funcionários para as boas práticas de fabricação e APPCC. A seguir foram aplicados os princípios do plano, sendo identificados 12 pontos críticos de controle (PCCs), desde a recepção do leite cru, até a expedição do produto acabado. O APPCC mostrou-se eficiente no controle da qualidade microbiológica do iogurte, com redução nas contagens de bolores e leveduras após a implantação do sistema, não sendo verificadas alterações para as contagens de coliformes totais e fecais. Quanto às perdas de embalagens na linha de produção, a implementação do APPCC não afetou os percentuais de perdas de tampas e garrafas, sendo que os rótulos apresentaram aumento de perdas após a implantação do sistema. Com relação aos custos para implantação do APPCC, os maiores investimentos foram referentes à consultoria externa $(48 \%)$ e mudanças estruturais e aquisição de equipamentos $(30 \%)$. Os custos específicos aos programas pré-requisitos representaram $22 \%$ dos investimentos totais. Para a manutenção do APPCC os maiores custos foram relativos à mão de obra para monitoramento dos PCCs e verificação do plano (46\%) e material de laboratório (28\%). O custo para a manutenção do sistema representou um impacto de $\mathrm{R} \$ 0,01 / \mathrm{kg}$ no valor final do iogurte embalado, e os gastos com investimentos na fábrica contribuíram com um adicional de $R \$ 0,02 / \mathrm{Kg}$. O impacto total da implementação do APPCC foi $\mathrm{R} \$ 0,03 / \mathrm{Kg}$, o que representa $1,5 \%$ do valor do produto 
final. Conclui-se que a aplicação do APPCC em linha de produção de iogurte conforme descrito neste estudo apresenta relação custo-benefício satisfatória.

Palavras-chave: APPCC; custo-benefício; iogurte; laticínio. 


\begin{abstract}
CUSATO, S. Cost-benefits relationship for implementation of the Hazard Analysis and Critical Control Points (HACCP) system in a dairy plant in the State of São Paulo. 2007. 113 f. Dissertation (Master) - Faculdade de Zootecnia e Engenharia de Alimentos, Universidade de São Paulo, Pirassununga, 2007.
\end{abstract}

The aim of this study was to evaluate the relationship between cost and benefits of Hazard Analysis Critical Control Points (HACCP) system implemented in the yogurt production line in a dairy processing plant in São Carlos, São Paulo State from August 2006 to August 2007. The total costs for the elaboration and implementation of HACCP, along with the microbiological parameters of the final product and the losses of packaging units during processing were measured before and after the implementation of the system. Initially, procedures were done for the compliance to the pre-requisites programs and the training of the staff on good manufacturing practices (GMP) and HACCP. Next, the principles of the plan were applied and 12 critical control points (CCP) were identified from the raw milk reception until the dispatch of the final product. The HACCP showed to be efficient for the microbiological quality control of the yogurt, by reducing the incidence of molds and yeasts, although no changes on total and fecal coliforms counts were observed before and after the HACCP implementation. As for the packaging losses on the production line, the implementation of the HACCP did not affect the percentage of bottles or bottle covers loss. However, the label losses increased after the HACCP implementation. Regarding the HACCP implementation costs, the major investments were related to external consultants (48\%) and structural changes and equipment purchasing (30\%). The specific costs related to the pre-requisite programs represented $22 \%$ of the total investments. The major costs for the HACCP operating were associated to the labor required for monitoring the CCP, the verification of the plan (46\%) and the material required for laboratorial analysis (28\%). The HACCP operating costs represented an impact of $R \$ 0.01 / \mathrm{kg}$ of the packed yogurt, and the investments done in the factory contributed for an additional of $R \$ 0.02 / \mathrm{kg}$. The overall impact of the HACCP implementation was $R \$ 0.03 / \mathrm{kg}(1.5 \%$ of the value of the 
final product). In conclusion, the HACCP applied in the yogurt line as described in this study presented a satisfactory cost-benefits relationship.

Key-words: HACCP; cost/benefit; yogurt; dairy. 


\section{LISTA DE FIGURAS}

Figura 1 - Árvore decisória para identificação dos pontos críticos de controle.......

Figura 2 - Etapas básicas do processo de fabricação de iogurte ......................... 30

Figura 3- Fluxograma de processamento dos iogurtes desnatado e parcialmente desnatado

Figura 4 - Temperaturas dos lotes de leite recebidos pelo laticínio no período de Janeiro a Agosto de 2007, antes e após a implantação do APPCC......

Figura 5 - Temperatura do leite armazenado no laticínio no período de Janeiro a Agosto de 2007, antes e após a implantação do APPCC.

Figura 6 - Valores dos investimentos relativos ao APPCC em suas diferentes etapas.

Figura 7 - Valores dos diversos tipos de investimentos relativos ao APPCC.......... amostras de iogurte analisadas antes e depois da implantação do APPCC

Figura 10 - Dispersão das contagens de coliformes totais (log ufc/g) nas amostras de iogurte analisadas antes e depois da implantação do APPCC

Figura 11 - Dispersão das contagens de coliformes fecais (log ufc/g) nas amostras de iogurte analisadas antes e depois da implantação do APPCC

Figura 12 - Percentuais de perdas diárias de garrafas na linha de produção de iogurte, antes e depois da implantação do APPCC.

Figura 13 - Percentuais de perdas mensais de garrafas na linha de produção de iogurte, antes e depois da implantação do APPCC

Figura 14 - Percentuais de perdas diárias de tampas na linha de produção de iogurte, antes e depois da implantação do APPCC.

Figura 15 - Percentuais de perdas mensais de tampas na linha de produção de iogurte, antes e depois da implantação do APPCC 
Figura 16 - Percentuais de perdas diárias de rótulos na linha de produção de iogurte, antes e depois da implantação do APPCC.............................. 100

Figura 17 - Percentuais de perdas mensais de rótulos na linha de produção de iogurte, antes e depois da implantação do APPCC. 


\section{LISTA DE QUADROS}

Quadro 1 - Descrição do plano de análise dos perigos e pontos críticos de controle (PCC 1 a 4): controle, limite crítico e formas e freqüências de monitoramento.

Quadro 2 - Descrição do plano de análise dos perigos e pontos críticos de controle (PCC 5 a 9): controle, limite crítico e formas e freqüências de monitoramento.

Quadro 3 - Descrição do plano de análise dos perigos e pontos críticos de controle (PCC 10 a 12): controle, limite crítico e formas e freqüências de monitoramento.

Quadro 4 - Descrição do plano de análise dos perigos e pontos críticos de controle (PCC 1 a 3): registro, responsável, ação corretiva e verificação.

Quadro 5 - Descrição do plano de análise dos perigos e pontos críticos de controle (PCC 4 a 6): registro, responsável, ação corretiva e verificação.

Quadro 6 - Descrição do plano de análise dos perigos e pontos críticos de controle (PCC 7 a 10): registro, responsável, ação corretiva e verificação.

Quadro 7 - Descrição do plano de análise dos perigos e pontos críticos de controle (PCC 11 e 12): registro, responsável, ação corretiva e verificação. 


\section{LISTA DE TABELAS}

Tabela 1 - Resultado da aplicação da Lista de Verificação para Boas Práticas de Fabricação (BPF) no laticínio.

Tabela 2 - Não conformidades com a Lista de Verificação para Boas Práticas de Fabricação (BPF) aplicada no laticínio.

Tabela 3 - Temas e sub temas das reuniões de treinamento em BPF ${ }^{1}, \mathrm{PPHO}^{2} \mathrm{e}$ $\mathrm{APPCC}^{3}$ aos funcionários do laticínio.

Tabela 4 - Padrões de qualidade físico-química e microbiológica estabelecidos pelo laticínio para os iogurtes desnatado e parcialmente desnatado......

Tabela 5 - Custos totais associados à elaboração, implementação e manutenção do plano APPCC no laticínio.

Tabela 6 - Custo da mão de obra para manutenção do APPCC*..

Tabela 7 - Contagem de bolores e leveduras, coliformes totais e coliformes fecais $^{1}$ antes e depois da implantação do APPCC.................................

Tabela 8 - Percentuais das perdas de garrafas, rótulos e tampas ${ }^{1}$ ocorridas na linha de produção, antes e após a implantação do APPCC ${ }^{2}$. 


\section{LISTA DE ABREVIATURAS E SÍMBOLOS}

$\begin{array}{ll}\text { ANVISA } & \text { Agência Nacional de Vigilância Sanitária } \\ \text { APPCC } & \text { Análise de Perigos e Pontos Críticos de Controle } \\ \text { BPF } & \text { Boas Práticas de Fabricação } \\ \text { CCS } & \text { Contagem de células somáticas } \\ \text { DVAs } & \text { Doenças veiculadas por alimentos } \\ \text { ESD } & \text { Extrato seco desengordurado } \\ \text { FZEA } & \text { Faculdade de Zootecnia e Engenharia de Alimentos } \\ \text { HACCP } & \text { Hazard Analysis and Critical Control Points } \\ \text { oC } & \text { Graus Celsius } \\ \text { oD } & \text { Graus Dornic } \\ \text { LANARA } & \text { Laboratório Nacional de Referência Animal } \\ \text { log } & \text { Logaritmo } \\ \text { MAPA } & \text { Ministério da Agricultura Pecuária e Abastecimento } \\ \text { MS } & \text { Ministério da Saúde } \\ \text { no } & \text { Número } \\ \text { \% } & \text { Porcentagem } \\ \text { P } & \text { Probabilidade } \\ \text { PCC } & \text { Ponto crítico de controle } \\ \text { PPHO } & \text { Procedimentos Padrão de Higiene Operacional } \\ \text { kg } & \text { Quilograma } \\ \text { R\$ } & \text { Valor monetário em reais } \\ \text { SIF } & \text { Serviço de Inspeção Federal } \\ \text { ufc/g } & \text { Unidades formadoras de colônia por grama } \\ \text { USP } & \text { Universidade de São Paulo } \\ & \end{array}$




\section{SUMÁRIO}

RESUMO

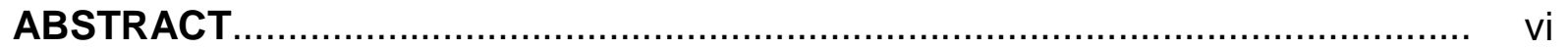

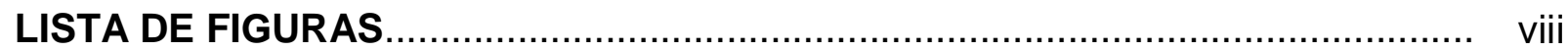

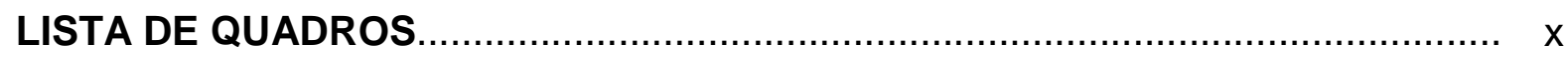

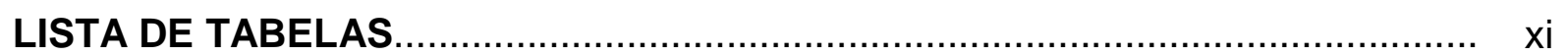

LISTA DE ABREVIATURAS E SÍMBOLOS ...................................................... xii

1 INTRODUÇÃO

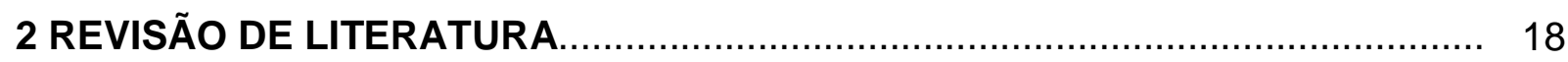

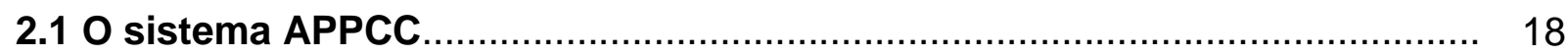

2.1.1 Princípios Gerais do Sistema APPCC................................................... 18

2.1.2 Relação Custo / Benefício do Sistema APPCC............................................ 22

2.2 A Relação entre a Qualidade e os Custos .................................................. 27

2.3 Tecnologia de Fabricação do logurte...................................................... 29

2.4 Controle de Qualidade e Segurança Alimentar na Fabricação de logurtes 35

2.4.1 Recepção e Armazenamento do Leite Cru ................................................. 35

2.4.2 Pasteurização ........................................................................................ 38

2.4.3 Fermentação e Resfriamento/Quebra do Coágulo ....................................... 39

2.4.4 Adição de Ingredientes e Envase .......................................................... 40

2.4.5 Recepção de Ingredientes e Embalagens ............................................. 41

2.4.6 Armazenamento do Produto Acabado e Expedição ....................................... 43

2.4.7 Higienização dos Equipamentos ......................................................... 44

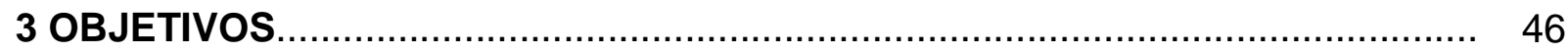

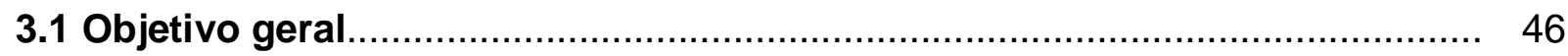

3.2 Objetivos específicos......................................................................... 46

4 MATERIAL E MÉTODOS .............................................................. 47

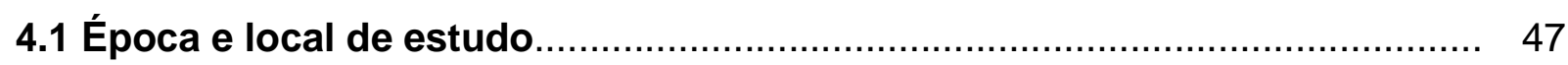

4.2 Aplicação do sistema APPCC.......................................................... 47

4.2.1 Procedimentos Preliminares................................................................... 47 
4.2.1.1 Comprometimento da gerência.......................................................... 47

4.2.1.2 Diagnóstico dos programas de pré-requisitos existentes............................. 48

4.2.1.3 Capacitação técnica - Treinamento em BPF............................................. 48

4.2.1.4 Formação da equipe....................................................................... 49

4.2.1.5 Descrição do produto...................................................................... 49

4.2.1.6 Elaboração e validação do fluxograma de processo..................................... 50

4.2.1.7 Treinamento da equipe APPCC....................................................... 50

4.2.2 Aplicação dos Princípios do APPCC........................................................ 50

4.3 Apuração dos custos do sistema APPCC................................................. 53

4.4 Avaliação dos benefícios do sistema APPCC.......................................... 54

4.4.1 Perdas de embalagens durante a produção................................................... 54

4.4.2 Qualidade microbiológica do produto acabado............................................ 55

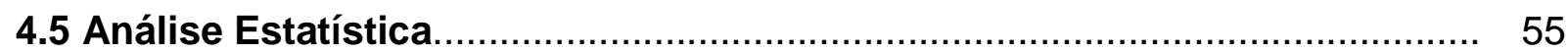

5 RESULTADOS E DISCUSSÃO ........................................................... 57

5.1 Adequação aos programas pré-requisitos................................................. 57

5.2 Treinamento dos manipuladores....................................................... 59

5.2.1 Perfil dos Funcionários.......................................................................... 59

5.2.2 Reuniões de Treinamento.................................................................... 60

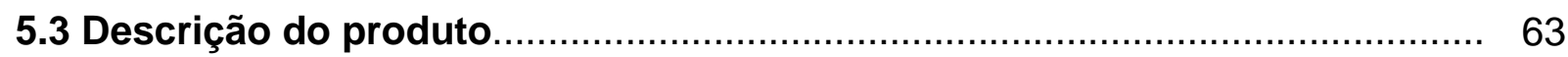

5.4 Fluxograma de processamento

5.5 Aplicação dos princípios do APPCC..................................................... 67

5.5.1 Levantamento dos Pontos para a Análise dos Perigos................................... 67

5.5.2 Identificação dos PCC e Medidas Preventivas............................................. 67

5.5.3 Determinação das Formas de Controle dos.PCCs.......................................... 70

5.5.4 O processo de Monitoramento................................................................ 78

5.6 Apuração dos custos do APPCC..................................................... 85

5.7 Avaliação dos benefícios do APPCC ...................................................... 93

5.7.1 Qualidade microbiológica do produto acabado ........................................... 93

5.7.2 Perdas de embalagens na linha de produção ………..................................... 96

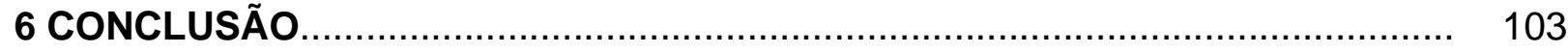

7 REFERÊNCIAS BIBLIOGRÁFICAS ......................................................... 104

ANEXOS 


\section{INTRODUÇÃO}

A segurança alimentar tem se tornado uma preocupação constante em todo o mundo, levando os órgãos de Saúde Pública e os governos de diversos países a buscarem formas de monitoramento de suas cadeias produtivas (MAKIYA; ROTONDARO, 2002).

Nas últimas décadas, importantes transformações ocorridas na área de alimentos têm se tornado um desafio aos processadores de alimentos na busca pela segurança, com destaque para as inovações nos processos de fabricação dos alimentos, redução do tempo entre a produção e o consumo, aumento da vida de prateleira dos produtos, aumento da prevalência de alguns microrganismos (STEVENSON, 1990; BAUMAN, 1990).

Com a globalização da cadeia de alimentos, as doenças veiculadas por alimentos (DVAs) adquiriram uma nova dimensão (MOTARJEMI; KÄFERSYEIN, 1999), representando um dos maiores problemas de saúde em termos mundiais pelo fato de afetar milhões de pessoas anualmente (GERMANO, 2003a) e provocar perdas econômicas e sociais significativas (RUEGG, 2003; SILVA, 1999). Dados da Organização Mundial de Saúde revelam que, somente no ano de 2005, 1,8 milhão de pessoas morreram em conseqüência de gastrenterites provocadas por alimentos e água contaminados (WHO, 2007). Apesar dos avanços tecnológicos nas áreas de produção e controle de alimentos, a ocorrência desse tipo de doença vem aumentando nos últimos anos, mesmo em países desenvolvidos (FRANCO; LANDGRAF, 2003).

No Brasil, as DVAs são responsáveis provavelmente por centenas de mortes e milhares de hospitalizações, embora os dados disponíveis não sejam precisos devido à sub-notificação. Apesar da precariedade das informações, estima-se que os alimentos de origem animal são os mais freqüentemente envolvidos em surtos de toxi-infecções alimentares, incluindo o leite e seus derivados (GERMANO, 2003a).

Do ponto de vista de Saúde Pública, o leite ocupa lugar de destaque na nutrição humana. Pelo seu elevado valor nutricional constitui-se alimento essencial dos recémnascidos e é indicado para pessoas de todas as idades, sendo as restrições ao seu uso limitadas a casos excepcionais. Contudo, ao lado da indiscutível qualidade intrínseca, há 
o permanente risco do leite ser veiculador de microrganismos patogênicos tornando-se prejudicial à saúde do consumidor (OLIVEIRA; FONSECA; GERMANO, 1999).

Os perigos potenciais dos produtos lácteos à saúde humana estão normalmente relacionados às falhas no processo de pasteurização, consumo de leite cru ou de produtos fabricados sem tratamento térmico, contaminação dos produtos lácteos por patógenos resistentes aos processamentos usuais, contaminações químicas ou ainda doenças dos animais transmitidas ao homem (RUEGG, 2003). Neste contexto, o sistema de análise de perigos e pontos críticos de controle (APPCC) apresenta-se como uma ferramenta que faz parte da moderna gestão da qualidade na indústria de alimentos, garantindo a integridade do produto, prevenção de DVAs e preservação da saúde do consumidor (MORTIMORE; WALLACE, 1998).

O Brasil é atualmente o sexto maior produtor mundial de leite, com 25,3 bilhões de litros previstos para o ano de 2007 (ANUARIO BRASILEIRO DA PECUARIA, 2007). Estimativas do International Food Policy Research Institute (IFPRI), ligado à Food and Agricultural Organization (FAO), mostram que até 2020 haverá um aumento de 87\% no consumo mundial de leite e derivados, com $84 \%$ desse aumento ocorrendo em países em desenvolvimento (PHILPOT, 2002). O Brasil, em particular, apresenta grande potencial de incremento no consumo e na produção de lácteos, sendo que, em anos recentes, o país vem inserindo-se de forma crescente no mercado exportador (CARVALHO, 2004).

Diversas conquistas do setor leiteiro brasileiro possibilitaram ao país mudar sua posição de segundo maior importador mundial para a de exportador, mantendo desde 2004, superávit na balança comercial de produtos lácteos, principalmente de leite em pó, queijo e leite condensado (MÔNACO, 2005). Deve-se ressaltar que o mercado internacional de lácteos é altamente competitivo, sendo necessário que o Brasil adote uma cultura exportadora que possibilite sua inserção crescente nesse mercado, incluindo a adequação às normas internacionais e às exigências dos países importadores.

As condições básicas para acesso a novos mercados compreendem a adoção de sistemas de gestão da qualidade que enfatizem a padronização dos produtos e processos, a rastreabilidade (TOLEDO, 2001) e a garantia da segurança alimentar. Novamente o APPCC apresenta-se como um instrumento eficaz, possibilitando que as empresas tornem-se competitivas no mercado nacional e internacional (UNNEVEHR; ROBERTS, 1996). No entanto, apesar do sistema ser reconhecido como uma das mais 
efetivas formas de garantir a qualidade e segurança dos alimentos (ROBERTO; BRANDÃO; da SILVA, 2006), sua adoção ainda é restrita e encontra-se relacionada ao porte da empresa e ao mercado onde ela atua. O APPCC mostra-se difundido de forma mais ampla entre as empresas voltadas para a exportação, motivadas pela necessidade de atender aos padrões de regulamentação impostos por outros paises e pelo interesse em manter acesso a esses mercados (DONOVAN; CASWELL; SALAY, 2001).

A utilização do APPCC entre as empresas de pequeno e médio porte é ainda reduzida (TAYLOR, 2003; EHIRI; MORRIS; McEWEN, 1995) o que, segundo Henson, Holt e Northen (1999), deve-se ao fato do sistema ser considerado como de custos elevados, ligados à economia de escala e principalmente pela falta de um claro entendimento dos benefícios trazidos pelo plano, os quais são tidos normalmente como limitados ou de natureza intangível.

A motivação para a implantação do sistema APPCC por parte da indústria está diretamente ligada às expectativas dos custos/benefícios a ele relacionados (HENSON; HOLT; NORTHEN, 1999). No Brasil, apesar de todas as ações adotadas pelo governo e mesmo pela iniciativa privada, é marcante a falta de conhecimento do APPCC pelos empresários e pelos técnicos da maioria das empresas de médio e pequeno porte. Somase a esse fato o número insuficiente de técnicos capazes de assessorar a implantação do sistema na indústria (MAKIYA; ROTONDARO, 2002) e a exigência relativamente baixa do cumprimento das normas por parte dos órgãos governamentais (DONOVAN; CASWELL; SALAY, 2001).

Diante dos aspectos mencionados, a proposição geral do presente trabalho foi implantar o sistema APPCC e avaliar os custos e os benefícios desta implantação em um laticínio, com a finalidade de gerar dados que possam subsidiar as empresas nas decisões para adoção do sistema, além de fornecer informações úteis aos órgãos de fiscalização quando da recomendação do sistema às indústrias de leite e derivados. 


\section{REVISÃO DE LITERATURA}

\subsection{O Sistema APPCC}

\subsubsection{Princípios Gerais do Sistema APPCC}

O método de Análise de Perigos e Pontos Críticos de Controle - APPCC (da sigla em inglês HACCP para Hazard Analysis and Critical Control Points) é um sistema preventivo que busca a obtenção de alimentos inócuos. Baseia-se em princípios técnicos e científicos aplicáveis a todas as fases da produção dos alimentos, desde o campo, passando pela indústria, sistemas de distribuição até o consumidor final (ICMSF, 1991).

O conceito básico do sistema é a prevenção (MORTIMORE; WALLACE, 1998), identificando as possíveis contaminações antes que elas ocorram e então estabelecendo medidas de controle que maximizem a segurança do alimento a cada passo da produção (CULLOR, 1997; LEITÃO, 1993). Portanto, o APPCC possibilita um controle mais rigoroso das contaminações, quando comparado com os métodos tradicionais de inspeção e controle de qualidade baseados na análise do produto acabado (STEVENSON, 1990).

Através da investigação sistemática, o APPCC permite identificar matérias primas e alimentos processados que possam conter substâncias tóxicas ou agentes de toxinfecções alimentares, ou serem fontes potenciais de contaminação. Além disso, o sistema permite determinar a possibilidade dos microrganismos sobreviverem ou multiplicarem-se durante a produção e processamento do alimento, sua distribuição, estocagem e preparo para o consumo (ICMSF, 1991).

O APPCC foi desenvolvido pela Pillsbury Co., a pedido da National Aeronautics and Space Administration - NASA na década de 60, com o objetivo de garantir a segurança dos alimentos utilizados pelo programa espacial americano (BAUMAN, 1990). $\mathrm{Na}$ década de 70 a sistemática passou a ser recomendada pelo Food and Drug Administration - FDA, ainda nos Estados Unidos e, mais recentemente, vem sendo preconizado por órgãos como a World Health Organization - WHO e a International Comission on Microbiological Specifications for Foods - ICMSF. O sistema é 
recomendado também pelo Codex Alimentarius e por agências regulamentadoras de produtos alimentícios de vários países, tornando-se uma referência mundial no que diz respeito ao controle da inocuidade dos alimentos.

No Brasil, as ações para adoção do sistema APPCC em escala industrial tiveram início em 1991, nos Estados do Rio de Janeiro, Ceará e Pará (COSTA JUNIOR, 1977), por iniciativa do segmento de pescados, juntamente com o Ministério da Agricultura Pecuária e do Abastecimento (MAPA), visando a sua implantação em caráter experimental (MAKIYA; ROTONDARO, 2002).

A obrigatoriedade do sistema foi regulamentada pelo Ministério da Saúde - MS através da Portaria no 1.428 de 26/10/1993, onde são fornecidas as diretrizes para o estabelecimento de Boas Práticas de Produção e de Serviços na Área de Alimentos e uso do APPCC (BRASIL, 1993). Em 1998, o MAPA, através da Portaria oo 46 de 10/02/1998 (BRASIL, 1998), instituiu o sistema APPCC para as indústrias de produtos de origem animal, assim como as diretrizes para o Manual Genérico de Procedimentos para o desenvolvimento do plano a ser implantado gradativamente pelas indústrias.

O sistema utiliza conceitos próprios, cuja terminologia, de acordo com Bryan (1993) e Silva (1999) inclui os seguintes termos:

- Perigo: contaminação inaceitável de natureza biológica (crescimento ou sobrevivência de microrganismos), química (pesticidas, antibióticos, metais pesados, produtos de limpeza) ou física (cacos de vidro, metal e outros), que tornam o alimento impróprio para o consumo;

- Gravidade ou Severidade: magnitude do perigo ou grau de conseqüências que podem resultar dele para a saúde. Com relação à severidade, as doenças podem ser classificadas em três categorias: letais, crônicas ou moderadas;

- Risco: estimativa da probabilidade da ocorrência de um perigo. Os graus de risco são classificados em alto, moderado e baixo, podendo variar de acordo com a situação;

- Ponto Crítico de Controle (PCC): um local, uma prática, um procedimento ou um processo sobre o qual pode-se exercer um controle com a finalidade de reduzir ao mínimo, prevenir ou eliminar um perigo; 
- Limite Crítico: valor ou atributo de natureza física (ex.: tempo; temperatura), química (ex: pH) ou biológica (ex: sensorial; microbiológica) estabelecido para cada ponto crítico e que indica se uma operação está ou não sob controle;

- Monitoramento: consiste na observação dos PCCs através de mensurações como tempo/temperatura, $\mathrm{pH}$, acidez ou ainda observações visuais para verificar se os limites críticos estabelecidos foram atingidos. Em caso negativo, o PCC está fora de controle e exige uma ação corretiva;

- Ação Corretiva: são medidas específicas e imediatas que devem ser tomadas sempre que os limites críticos não forem atingidos;

- Verificação: consiste em testes complementares e/ou revisão dos registros de monitoramento para confirmar se o plano APPCC esta funcionando como planejado. A verificação pode levar, caso necessário, a alterações em alguma das etapas do sistema de forma a garantir a segurança do alimento produzido;

- Árvore Decisória: seqüência lógica de perguntas que, ao serem respondidas permitem identificar se uma determinada matéria prima, etapa do processamento ou ingrediente é um PCC (Figura 1).

Desde que foi criado, o APPCC passou por algumas modificações e, em 1991, através de documento publicado pela National Advisory Committee on Microbiological Criteria for Foods - NACMCF, foram estabelecidos os seus princípios básicos na forma como são conhecidos atualmente (ALMEIDA, 1998).

Anteriormente à aplicação dos princípios que compõem o plano, no entanto, devem ser garantidas as condições higiênicas básicas com relação às boas práticas de fabricação e higienização no local do processamento. Os programas ligados a essas práticas são reconhecidos como "programas pré-requisitos" e desde que corretamente implementados, fornecem os princípios para o correto manuseio de alimentos, tornando o sistema mais eficiente e fácil de ser administrado (WALLACE; WILLIAMS, 2001).

Os "programas pré-requisitos", compostos por Boas Práticas de Fabricação (BPF) e Procedimentos - Padrão de Higiene Operacional (PPHO), devem contemplar os seguintes aspectos: estrutura física e manutenção das instalações, abastecimentos de água, saúde e hábitos higiênicos dos manipuladores, controle de pragas, higienização das instalações e equipamentos, aferição de instrumentos, controle da qualidade da matéria- 
prima e ingredientes, procedimentos de recolhimento do produto final (recall) e procedimento sobre reclamações de consumidores (BRASIL, 1998).

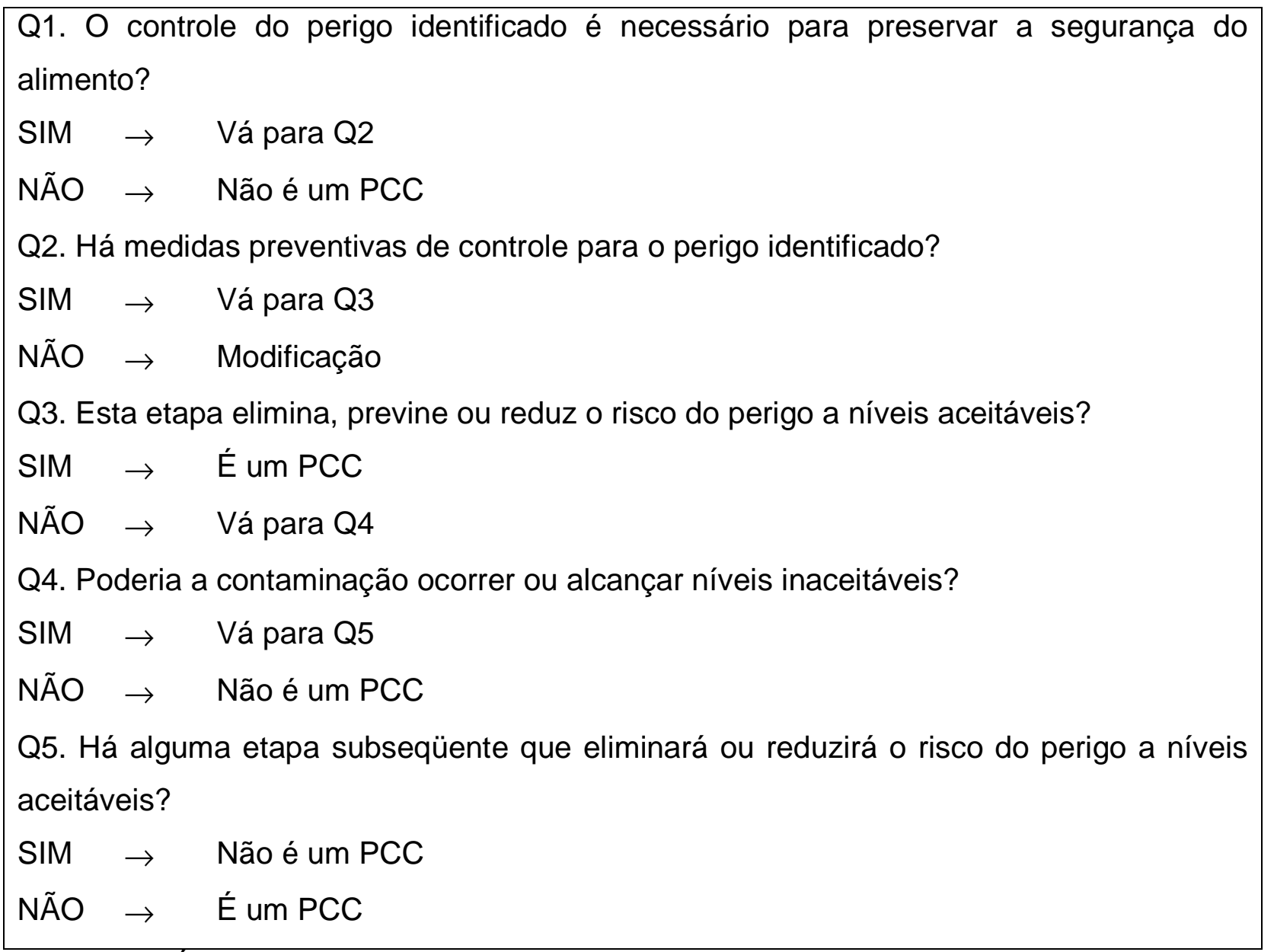

Figura 1 - Árvore decisória para identificação dos pontos críticos de controle (CEZARI; NASCIMENTO, 1995)

De acordo com SENAI (2000), a direção da empresa deve estar comprometida com os objetivos do plano e consciente dos recursos a serem disponibilizados. A equipe responsável pela elaboração e implementação do APPCC deve ser multidisciplinar, com conhecimentos nas áreas de produção, engenharia, saúde, microbiologia e garantia de qualidade. É importante também que na equipe estejam incluídas pessoas diretamente ligadas às atividades diárias do estabelecimento, pois além de contribuírem com informações sobre as particularidades e limitações do processo de produção, possibilitam a criação de um sentimento de compromisso com o plano.

Faz-se necessário o treinamento de todos os envolvidos permitindo 0 conhecimento de todos os aspectos ligados ao plano, bem como a criação de um 
programa de capacitação continuada que possibilite a atualização e reciclagem dos mesmos (CEZARI; NASCIMENTO, 1995).

A equipe APPCC deve reconhecer de forma detalhada o alimento em questão, seus ingredientes e formulação, material de embalagem e métodos de armazenamento, distribuição e exposição para venda, além de cuidados no manuseio, shelf life e tipo de consumidor a que se destina. É necessária a elaboração de um fluxograma de processo com a descrição de todas as etapas envolvidas e que deve ser validado periodicamente, garantindo que reflita a situação real (CORLETT JUNIOR, 1998).

Cumpridas as etapas preliminares estão criadas as condições básicas para a aplicação dos princípios do plano (WALLACE; WILLIAMS, 2001). O sucesso da sua implantação, como ferramenta para a garantia da segurança do alimento, depende do entendimento e da correta aplicação desses princípios (MOTARJEMI; KÄFERSTEIN, 1999), citados por Mayes e Mortimore (2003) e Cullor (1997) como se segue:

1. Efetuar uma análise de perigos e identificar as medidas preventivas respectivas;

2. Identificar os pontos críticos de controle (PCC) com a ajuda, se necessário, da árvore decisória;

3. Estabelecer limites críticos para as medidas preventivas associadas com cada PCC;

4. Estabelecer as formas de monitoramento dos PCCs e os procedimentos para utilização dos resultados que permitam ajustar o processo e mantê-lo sobre controle;

5. Estabelecer ações corretivas para o caso de desvio dos limites críticos;

6. Estabelecer um sistema para registro de todos os controles;

7. Estabelecer procedimentos de verificação.

\subsubsection{Relação Custo / Benefício do Sistema APPCC}

De maneira geral, as empresas encontram dificuldades em visualizar de forma clara os custos e os benefícios provenientes do APPCC (MALDONADO et al., 2005). A falta de conhecimentos sobre os princípios e o funcionamento do plano dificultam a identificação desses custos, impedindo de separá-los dos custos de produção (BUCHWEITZ; SALAY, 2006; DONOVAN; CASWELL; SALAY, 2001). Assim, os valores 
reais do custo do sistema tornam-se difíceis de serem obtidos, ficando somente por conta da percepção dos administradores e tendendo a ser superestimados.

O APPCC geralmente envolve elevados custos fixos relacionados a sua elaboração, ao treinamento de funcionários e à aquisição de equipamentos, conferindo ao plano a necessidade de uma economia de escala (UNNEVEHR; ROBERTS, 1996). Maldonado et al. (2005) destacam a importância das empresas avaliarem a magnitude dos custos do sistema, antes da sua implementação, fato pouco comum, confirmado por estudo conduzido por Henson, Holt e Northen (1999), onde menos de 15\% das indústrias pesquisadas possuíam estimativa dos custos envolvidos antes de iniciarem a implantação do APPCC.

Para proceder à apuração de custos em qualquer atividade, torna-se importante definir claramente os objetivos a serem atingidos, sendo necessário o conhecimento de alguns conceitos fundamentais que permitam maior segurança na obtenção dos dados e na análise dos resultados (FIGUEIREDO, 2001). Deste modo, o termo custo pode ser definido como gasto (pagamento) relativo a um bem ou serviço utilizado na produção de outros bens ou serviços (MARTINS, 1996), ou ainda como o total de recursos, medido em termos monetários, sacrificados ou previstos para alcançar um objetivo específico (FIGUEIREDO, 2001).

Já Martins (1996) e ludícibus e Marion (2000) definem outros conceitos importantes, como:

- Objeto de custeio: é o objeto a ser custeado, podendo ser uma operação, uma atividade, um produto ou um programa que consome recursos;

- Direcionadores de custos: são os fatores cuja mudança altera conseqüentemente o custo do objeto de custeio. Por exemplo: o número de pessoas envolvidas em um programa de treinamento ou de reciclagem de pessoal influencia diretamente o custo do programa;

- Investimento: é todo o gasto que trará benefícios futuros para a empresa, ou seja, ao longo do tempo;

- Perda: é um gasto involuntário, anormal e imprevisível que é retirado do ativo, mas que não gera receita.

Os custos do sistema APPCC compreendem a somatória de todos os recursos disponibilizados nas suas diferentes etapas. Em estudo conduzido por Bata et al. (2006), 
os principais componentes dos custos na elaboração do plano foram os gastos com consultoria externa e aqueles decorrentes do afastamento da equipe APPCC de suas atribuições diárias. Na etapa de implementação, os autores citam gastos com treinamento de pessoal, com a adequação aos programas pré-requisitos e itens específicos do APPCC. Durante a manutenção do plano, custos do tempo gasto para o monitoramento dos PCCs e para os registros de ações corretivas foram os principais.

O nível tecnológico individual da planta industrial e a não adequação aos programas pré-requisito contribuem para que os custos de implantação do APPCC sejam mais elevados (McALOON, 2003; SUWANRANGSI, 2000). O padrão de adequação às boas práticas de fabricação, trazidos por esses programas facilitam a implementação do plano, reduzindo o número de pontos críticos de controle (PCCs) (BATA et al., 2006; HENSON; HOLT; NORTHEN; 1999) os quais, quando em o número elevado dificultam o gerenciamento e consomem muito tempo para auditorias (WALLACE; WILLIANS, 2001).

$\mathrm{Na}$ literatura ainda são relacionados vários itens que podem compor os custos totais para implantação do sistema APPCC como: aquisição de equipamentos, análises laboratoriais, alterações no processamento, mudanças estruturais na planta, tempo gasto com a documentação e contratação de pessoal para monitoramento dos PCCs (MOTARJEMI; KÄFERSTEIN, 1999; ROBERTO; BRANDÃO; da SILVA, 2006; DONOVAN; CASWELL; SALAY, 2001; CASWELL, 2000).

O impacto maior ou menor de tais elementos no custo total do APPCC depende das particularidades de cada planta; no entanto, os custos freqüentemente apontados como os mais elevados na implantação e operacionalização do sistema são: treinamento de pessoal, o tempo necessário para elaborar a documentação e o monitoramento e registros dos PCCs (BATA et al. 2006), muitas vezes com a contratação de funcionário extra para essa atividade. De acordo com Henson; Holt e Northen (1999), apesar de difícil mensuração, os gastos relativos ao tempo necessário para documentações e registros, geralmente superam as expectativas.

O tempo necessário para implantação do sistema pode variar, de alguns meses a vários anos e depende do nível de qualificação dos funcionários, complexidade do processo de produção (DONOVAN; CASWELL; SALAY, 2001), número de PCCs encontrados e das condições iniciais. 
Com relação ao material humano, a falta de pessoal capacitado para desenvolver e implementar todos os elementos do APPCC leva a maioria das empresas de médio porte a recorrer à consultoria externa (BATA et al., 2006), contribuindo para o aumento dos custos do sistema.

No que diz respeito ao treinamento dos funcionários, podem ser relacionados gastos com cursos externos para a equipe APPCC, incluindo viagens, transporte, refeições e perdas de produtividade pelo afastamento do trabalho ou ainda paralisação da produção quando o treinamento se destina a todos os funcionários (DONOVAN; CASWELL; SALAY, 2001). Nesse aspecto, o treinamento do pessoal que conduzirá o plano e a motivação da equipe incluindo aqueles ligados à produção e gerentes e supervisores são citados como as principais dificuldades encontradas pelas empresas (HENSON; HOLT; NORTHEN, 1999; MALDONADO et al., 2005).

Com relação às vantagens atribuídas à implantação do sistema APPCC, são citados na literatura diversos benefícios, muitos deles de natureza intangível ou difíceis de serem quantificados. O consumidor é o principal beneficiado, pois tem sua saúde assegurada, além de acesso a produtos com padrão de qualidade mais elevados (CASWELL, 2000; BAUMAN, 1995).

Os benefícios para o setor público dizem respeito à redução de custos com os serviços de saúde pública e com o afastamento de pessoas do trabalho, além de maior facilidade de monitoramento para as agências reguladoras do setor com redução do tempo gasto para auditorias e custos com análises (DONOVAN; CASWELL; SALAY, 2001; UNNEVEHR; ROBERTS, 1996).

É na indústria, porém, que pode-se encontrar o maior número de vantagens provenientes da implantação do sistema APPCC, inicialmente pela adequação às regulamentações governamentais, além de redução de incidentes provocados pela ausência de segurança alimentar (BAUMAN, 1995). Vantagens econômicas originam-se do melhor controle do processo, da redução do reprocessamento na linha de produção, de menores perdas de matéria prima e produto acabado, da redução da contagem microbiológica e conseqüente aumento da vida de prateleira dos produtos, além de ganhos na eficiência da produção (HENSON; HOLT; NORTHEN, 1999; DONOVAN; CASWELL; SALAY, 2001; MALDONADO et al., 2005). 
Hajdenwurcell (2002) cita como outras vantagens, a redução do número de análises laboratoriais necessárias para o produto acabado, redução do plano de amostragem no controle do processo, pelo controle preventivo dos PCCs e redução de produtos em desacordo com as especificações (não conformidades). O autor acrescenta ainda que os erros operacionais, provocados por falhas humanas, podem ser menos freqüentes, em decorrência da melhor capacitação e conscientização dos manipuladores.

Após a implantação do APPCC na Cargill, McAloon (2003) relata que o sistema possibilitou melhor controle do processamento, reduziu perdas e o retrabalho, aumentou a segurança dos alimentos e trouxe maior comprometimento por parte dos funcionários. Complementarmente, o autor cita o aumento de produtividade e menores custos de produção. Marthi (2003), ao implantar o APPCC na indústria de pescados na Índia, também aponta como benefícios do plano o aumento da produtividade pela redução de interrupções na produção, e melhor qualidade das matérias primas.

A aplicação do APPCC amplia as possibilidades de exportação já que o sistema permite harmonização com os requisitos do mercado internacional (UNNEVEHR; ROBERTS, 1996), além de contribuir para a imagem positiva da empresa gerando maior confiança por parte do consumidor e reduzindo as possibilidades de recall de produtos (EHIRI; MORRIS; McEWEN, 1995; MOTARJEMI; KÄFERSTEIN,1999).

De acordo com Bauman (1995), o recall pode gerar custos elevados provenientes da destruição de produtos, da queda de vendas momentâneas e da redução de vendas futuras gerada pela repercussão negativa sobre o produto. Acrescenta-se ainda a possibilidade de ações legais e responsabilidade financeira, além de custos de difícil mensuração como perda da reputação da empresa diante do consumidor e efeitos sobre a venda de outros produtos.

Em pesquisa realizada com processadores de pescados no Brasil, Donovan, Caswell e Salay (2001) apontam como vantagens do plano a melhora da qualidade das matérias primas, pelo maior controle junto aos fornecedores e como conseqüência maior qualidade do produto final.

Os ganhos resultantes do APPCC para a imagem da empresa são mais difíceis de serem mensurados, no entanto, são inegáveis, pois permitem maior competitividade e permanência no mercado, maior confiança por parte dos consumidores, maior 
conformidade dos produtos ou serviços oferecidos (BATA et al., 2006) e menor índice de reclamações por parte dos consumidores (MOTARJEMI; KÄFERSTEIN, 1999).

Diante de um mercado tão competitivo como o atual, a obtenção desses ganhos pela empresa pode fazer a diferença entre permanecer ou sair do mercado.

A redução da contagem microbiológica dos produtos e a capacidade de atrair novos clientes, além de manter a fidelidade dos já existentes, foram reconhecidos como os maiores benefícios obtidos com a implantação o sistema em laticínios do Reino Unido (HENSON; HOLT; NORTHEN; 1999). Maldonado et al. (2005) acrescentam que a percepção dos benefícios por parte dos consumidores depende, no entanto, da conscientização destes com relação à segurança alimentar.

Donovan, Caswell e Salay (2001) citam que a adoção do sistema APPCC está concentrada entre as empresas voltadas ao mercado exportador, motivadas pelo interesse em manter esses mercados. De acordo com esses autores, para aquelas empresas voltadas ao mercado interno, a percepção sobre o APPCC é de que os custos superam os benefícios, mostrando que a ausência de avaliação acurada de tais custos é um limitante à sua adoção.

Apesar do APPCC ser recomendado como uma das mais efetivas formas de garantir a qualidade e segurança dos alimentos, sua adoção é mais facilitada por parte das empresas de grande porte, com disponibilidade de recursos financeiros e pessoal com o conhecimento técnico necessário. Nesse contexto, há referências de que tais incentivos não têm sido suficientes para estimular sua adoção por parte das empresas de pequeno e médio porte e/ou por aquelas que operam com margens reduzidas de lucro (HENSON; HOLT; NORTHEN, 1999).

\subsection{A Relação entre a Qualidade e os Custos}

Qualidade pode ser definida, dentre muitas outras formas, como sendo as características do produto que vão ao encontro das necessidades do consumidor e propiciam sua satisfação em relação ao mesmo. Ou ainda como sendo a ausência de falhas ou deficiências de um produto que, quando existem, causam transtornos aos consumidores (JURAN, 1990).

A insatisfação do consumidor, gerada pelas deficiências apresentadas pelo produto, é expressa através de reclamações, devoluções, queixas e em casos mais 
extremos o cliente deixa de comprar o produto. Essas reações por parte do consumidor atingem o fornecedor através de diminuição das vendas e conseqüente aumento de custos (JURAN, 1991). Assim, a questão da qualidade é percebida pelas empresas não somente através da perfeição técnica, mas também por estar relacionada ao seu desempenho mercadológico e econômico, passando a ter sentido comercial e competitivo e sendo incorporada ao nível estratégico das empresas (TOLEDO, 2001).

Para seu melhor entendimento e controle, a qualidade pode ser subdividida em qualidade de projeto, relacionada com a adequação do produto ao mercado, e qualidade de conformação, relativa ao atendimento das especificações do projeto durante a fabricação do produto (BORNIA, 2002). Nesse aspecto Juran (1992) cita que as conformidades devem ser os meios para atingir as necessidades do consumidor.

De acordo com Deming (1990), esses eventos ocorrem como uma reação em cadeia onde a melhor qualidade conduz a custos menores, pela redução de erros e retrabalho, promovendo aumento da produtividade, captação de novos mercados e manutenção dos negócios.

Em virtude da importância que a qualidade ou falta dela passou a ter para as empresas, um novo conceito vem sendo cada vez mais utilizado atualmente: trata-se do "custo da qualidade", o qual pode ser definido como o custo da má qualidade, baseado principalmente sobre os custos para se identificar e corrigir o trabalho defeituoso. De acordo com Gryna (1991), os custos da má qualidade podem ser divididos em quatro categorias:

- Custos das falhas internas: estão relacionados aos defeitos antes da transferência do produto ao consumidor. Tais custos desapareceriam caso não existissem defeitos no produto antes da expedição e estão relacionados ao retrabalho (custo para corrigir os defeitos tornando-os adequados ao uso), ao descarte proveniente de produtos rejeitados ou defeituosos, e ao descarte e retrabalho devido a produtos não conformes recebidos dos fornecedores;

- Custos das falhas externas: são associados aos defeitos que são encontrados após o produto ter sido enviado ao cliente, tais como despesas com garantia, correção das reclamações e material devolvido;

- Custos de avaliação: são os custos incorridos na determinação do grau de conformidade aos requisitos de qualidade como: inspeção, testes do produto e auditorias; 
- Custos de prevenção: são os custos incorridos para manter em níveis mínimos os custos das falhas, onde estão incluídos o controle de processo, a avaliação da qualidade do fornecedor e o treinamento dos funcionários.

Para se manterem competitivas no mercado, as empresas devem concentrar esforços na busca constante pelo aprimoramento da qualidade, e nesse processo de melhoria contínua a eliminação de desperdícios é peça fundamental (BORNIA, 2002). Segundo Deming (1990), as deficiências e falhas que chegam às mãos do consumidor resultam em perda de mercado, pois um consumidor insatisfeito tem efeito multiplicador, gerando prejuízos difíceis de serem mensurados.

De acordo com Feigenbaum (1994), a qualidade dos materiais adquiridos de outras empresas e que participarão da produção contribuem para a confiabilidade do produto final e as atividades voltadas à garantia de qualidade desses materiais constituem elementos básicos de programas de controle de qualidade.

A busca pela qualidade é um desafio para as empresas e, em seu caminho, diversos aspectos devem ser considerados. Segundo Bornia (2002) engloba a satisfação dos desejos do mercado pelo projeto, a manufatura confiável e sem defeitos, o preço de venda acessível aos consumidores, a segurança e adequação ao meio ambiente e o atendimento aos prazos locais e quantidades exigidas, sem falar nos serviços de assistência técnica e o relacionamento com fornecedores e funcionários. Em síntese, como afirma Juran (1990), a qualidade no sentido de ausência de defeitos deve, em longo prazo, buscar a perfeição.

\subsection{Tecnologia de Fabricação do logurte}

O iogurte é o mais popular dos leites fermentados (STAFF, 2000), obtido a partir da fermentação do leite por bactérias lácticas selecionadas, resultando em um produto com sabor e aroma característicos (WALSTRA et al., 2001). Seu processo de fabricação é bastante antigo, datado de milhares de anos e sua sobrevivência até os dias de hoje é atribuída à produção em pequena escala, como uma espécie de "arte", transmitida de geração a geração (TAMINE; ROBINSON, 1991).

Embora o consumo de iogurte tenha por muito tempo se restringindo apenas a certos grupos étnicos, o produto é atualmente bastante difundido, graças à diversidade de 
formas de apresentação, com adição de frutas e distintos sabores (VARNAM; SUTHERLAND, 1994) que atenuam seu sabor ácido e garantem maior aceitação popular.

De uma forma geral os iogurtes são classificados de acordo com a consistência que apresentam, as quais dependem do processo de fabricação e dos ingredientes utilizados. Assim os principais tipos são: iogurte firme, iogurte batido e iogurte para beber (SPEER, 1998). Muitos países possuem uma legislação específica que regulamenta a composição dos diversos tipos de iogurte, fixando valores mínimos para os teores de sólidos e proteína, classificando-os quanto ao teor de gordura e estabelecendo o tipo de cultivo utilizado (STAFF, 2000). De acordo com Varnam e Sutherland (1994), tais padrões são definidos na indústria de forma a atenderem não somente a legislação vigente como também a preferência dos consumidores.

Embora existam algumas particularidades na fabricação dos distintos tipos de iogurte, sua elaboração é composta de algumas etapas básicas, como apresentadas na Figura 2 (VEISSEYRE, 1988; TAMINE; ROBINSON, 1991; SPEER, 1998; STAFF, 2000).

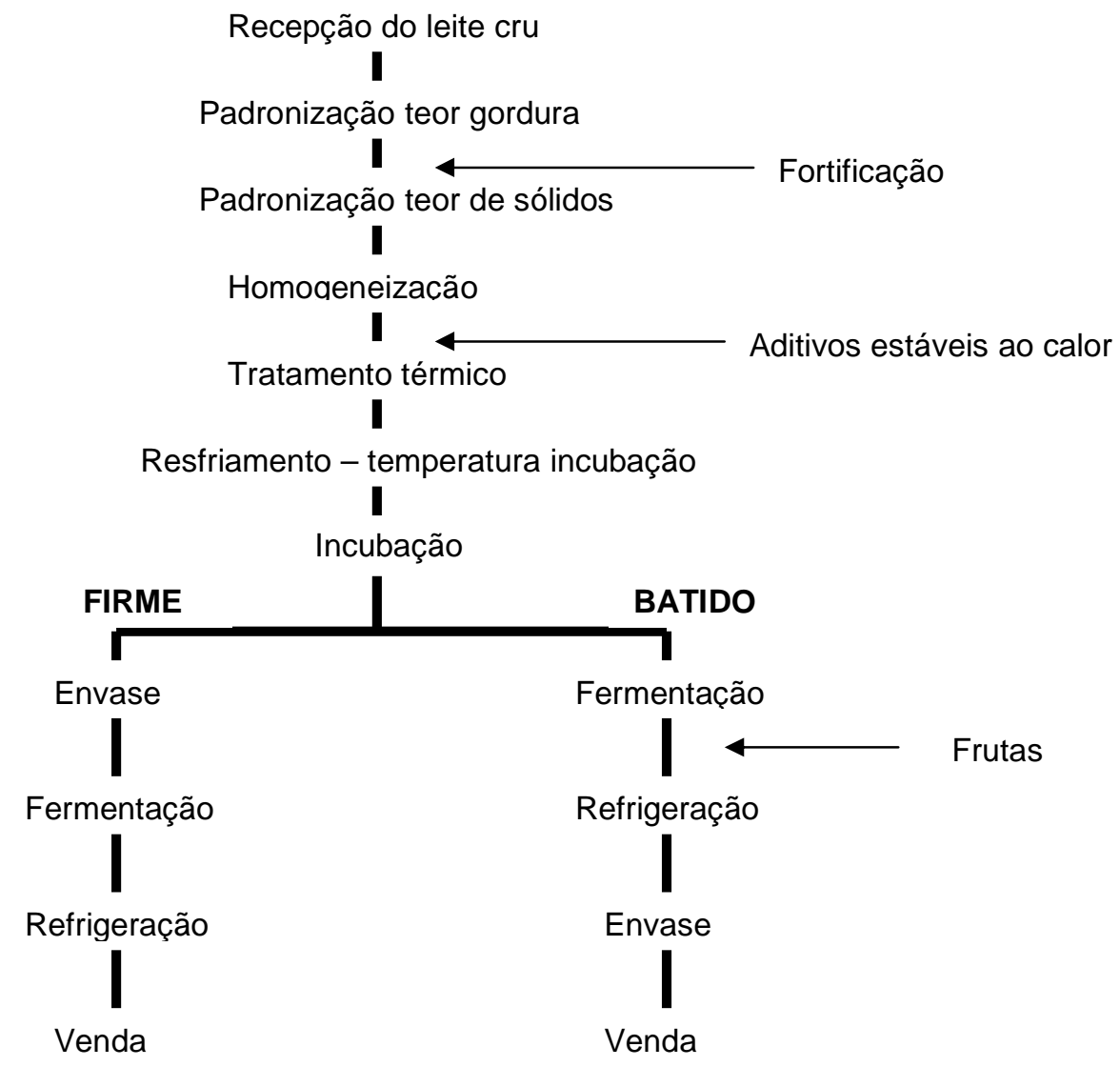

Figura 2 - Etapas básicas do processo de fabricação de iogurte 
O leite fluido é a principal matéria prima para a fabricação do iogurte e sua composição interfere diretamente sobre a qualidade do produto final. A lactose é fonte de energia para os microrganismos iniciadores e a proteínas desempenham um papel fundamental na formação do coágulo sendo a consistência e viscosidade do produto diretamente proporcionais à concentração de proteína do leite (TAMINE; ROBINSON, 1991).

O teor de gordura do leite deve ser padronizado de acordo com seu teor no produto final e neste caso vários métodos podem ser empregados como eliminação da gordura através de centrifugação, mistura de leite integral e desnatado, adição de nata ao leite integral ou desnatado (VARNAM; SUTHERLAND, 1994).

O teor de extrato seco desengordurado (ESD) do leite, que inclui principalmente lactose, proteína e minerais, é de significativa importância para as propriedades físicas do iogurte. Quanto maior o conteúdo de ESD da mistura destinada à sua elaboração, melhor a consistência do produto final e menor a tendência de sinerese (VARNAM; SUTHERLAND, 1994). O ajuste do ESD pode ser realizado através da concentração do leite por evaporação ou então pela adição de produtos como leite em pó e concentrado protéico (SPEER, 1998). De acordo com Staff (2000), melhores condições de textura e viscosidade podem ser obtidas quando se eleva a concentração de ESD para valores a partir de $12-15 \%$.

Deve-se salientar que os ingredientes utilizados para correção do ESD merecem os mesmos cuidados com relação à presença de contaminações químicas e microbiológicas dispensados ao leite fluido.

A padronização do leite quanto ao conteúdo de gordura e extrato seco desengordurado tem a função de cumprir as especificações exigidas pela legislação além de atingir os padrões de suavidade e consistência satisfazendo as exigências dos consumidores.

Depois de padronizada, a base láctea é homogeneizada e recebe um tratamento térmico, estando então preparada para a incubação. No processo de homogeneização ocorre a redução do diâmetro médio dos glóbulos de gordura para valores próximos de 2 $\mu \mathrm{m}$. Esse procedimento tem objetivo de evitar o acúmulo da gordura na superfície do tanque durante a fermentação e tem efeitos adicionais como facilitar a mistura quando se 
utiliza leite em pó, reduzir a tendência de sinerese e aumentar a viscosidade do iogurte (TAMINE; ROBINSON, 1991).

Após a pasteurização se procede ao resfriamento da base láctea até a temperatura próxima de 40-45 ำ para incubação do cultivo iniciador, que consiste em bactérias ácido lácticas, responsáveis pela acidificação e fermentação do leite (SPEER, 1998). Os cultivos comerciais mais utilizados são Lactobacillus delbrueckii ssp. bulgaricus e Streptococcus thermophilus apresentados na forma líquida, congelados, desidratados ou liofilizados (STAFF, 2000).

As duas espécies de bactérias convivem em simbiose, com a liberação de fatores estimulantes durante o período de incubação através do fenômeno denominado protocooperação (WALSTRA et al., 2001). O Lactobacillus ativa o crescimento do Streptococcus através de sua ação proteolítica sobre as proteínas do leite liberando aminoácidos ao meio, principalmente valina. $\mathrm{O}$ pH inicial do leite é mais favorável para os Streptococcus que então predominam e iniciam a fermentação láctica liberando $\mathrm{CO}_{2}$, ácido láctico e compostos voláteis como o ácido fórmico. Com a queda progressiva do pH, o crescimento do Streptococcus é inibido e os Lactobacillus, que resistem melhor ao $\mathrm{pH}$ baixo, tem seu desenvolvimento estimulado pelas condições de anaerobiose formada e pelos metabólitos liberados pelo Streptococcus (VEISSEYRE, 1988).

Assim, além do protocooperativismo, há no iogurte uma relação de antibiose já que os cocos não se desenvolvem a partir de uma determinada acidez e os bacilos são mais resistentes a essas condições mantendo seu crescimento. Os efeitos de protocooperação e antibiose são fundamentais para o desenvolvimento das bactérias do iogurte e sobre a qualidade do produto final (WALSTRA et al., 2001).

Metabólitos do desenvolvimento microbiano como ácido láctico, acetaldeído e polissacarídeos contribuem para estrutura e consistência do iogurte e determinam seu aroma característico (SPEER, 1998). A acidificação do leite durante a fermentação desestabiliza a caseína, favorecendo sua agregação e formando um gel ácido (TAMINE; ROBINSON, 1991). A produção de substâncias viscosas pelo cultivo iniciador, como polissacarídeos, tem importante papel na estabilização do coágulo do iogurte, formando uma rede de substâncias mucilaginosas que unem as micelas protéicas em aglomerados de caseína (VARNAM; SUTHERLAND, 1994). 
De acordo com Tamine e Robinson (1991), as modificações físicas e químicas do leite durante a fermentação podem ser assim resumidas:

- metabolização da lactose pelos cultivos starter resultando na formação de ácido láctico e outros compostos importantes;

- desestabilização dos complexos de caseína-proteína do lactossoro pela solubilização do fosfato de cálcio e dos citratos;

- agregação das micelas de caseína à medida que o pH se aproxima de seu ponto isoelétrico $(\mathrm{pH} \mathrm{4,6-4,7);}$

- formação do gel protegido externamente pela interação das proteínas do lactossoro e a К-caseína e contendo também em seu interior a fase aquosa.

Atingido o pH desejado, o processo de fermentação é interrompido o mais rapidamente possível para assim controlar a acidez final do produto. O resfriamento pode ser feito em uma única fase até a temperatura final ou em duas fases para adição de frutas e aromatizantes e posterior envase.

Edulcorantes podem ser adicionados para atenuar a acidez desenvolvida durante a fermentação especialmente na elaboração de iogurtes com frutas muito ácidas ou que contenham pouco açúcar. Os mais freqüentemente utilizados são: sacarose e glicose além dos sintéticos: aspartame e sacarina para iogurtes com baixas calorias. A quantidade de edulcorante a ser utilizada depende de fatores como: tipo de edulcorante, preferência dos consumidores, aspectos econômicos, exigências legais, efeitos inibidores sobre o cultivo starter (STAFF, 2000).

O tratamento mecânico a que é submetido o iogurte durante o processamento através de agitação no tanque de fermentação, bombeamento, mistura para incorporação de frutas e aromas provocam o rompimento do coágulo, diminuição da viscosidade e em casos extremos separação do soro (TAMINE; ROBINSON, 1991). Tais defeitos podem ser evitados pela adição de estabilizantes como amidos naturais, alginatos, agar, carragenano, pectina, celulose (STAFF, 2000).

Para os iogurtes com sabores de frutas estas são adicionadas juntamente com os corantes, após a fermentação podendo ser na forma de frutas frescas, congeladas ou purê (STAFF, 2000).

$\mathrm{O}$ baixo pH final atingido pelo iogurte é um fator de inibição para a maior parte dos microrganismos, favorecendo, no entanto, o crescimento de bolores e leveduras como 
microrganismos alterantes. Em alguns casos, com a finalidade de controlar esse tipo de contaminação são utilizados conservantes químicos como benzoato e sorbato de potássio, (VARNAM; SUTHERLAND, 1994) sendo este último seletivo contra bolores e leveduras, não afetando o cultivo starter (STAFF, 2000).

Para a escolha do estabilizante e/ou conservante e definição das quantidades a serem utilizadas deve-se considerar as normas legais existentes em cada país e que autorizam seu uso.

A etapa final do processamento é o envase do iogurte que tem como principais objetivos acondicionar o produto em recipiente que permita protegê-lo dos agentes externos, evitando assim contaminações, impedindo a perda de substâncias voláteis responsáveis pelo seu aroma característico, além de facilitar o manuseio durante o armazenamento e transporte até o consumidor final (WALSTRA, 2001).

A embalagem pode ser de variados tipos e materiais: as rígidas como vidro, as semirigidas como polietileno em diversos formatos e seladas com lâminas de alumínio termoseladas ou tampas plásticas sob pressão ou ainda as embalagens flexíveis cartonadas (TAMINE; ROBINSON, 1991).

Diante dos detalhes apresentados sobre a tecnologia de produção, verificamos que o iogurte é um produto bastante sensível às variações no processamento, as quais podem resultar em não conformidades com relação às suas especificações e, provavelmente, insatisfação por parte do consumidor. Nesse cenário, a implantação do APPCC é uma ferramenta muito interessante para garantir um elevado padrão de qualidade do produto que possa ser reconhecida pelo consumidor. A satisfação do consumidor, então, garantiria competitividade no mercado, concomitantemente a uma maior eficiência no processamento industrial. Como resultado final, podemos obter uma relação custo/benefício bastante positiva. 


\subsection{Controle de Qualidade e Segurança Alimentar na Fabricação de logurtes}

\subsubsection{Recepção e Armazenamento do Leite Cru}

A qualidade do leite, em termos microbiológicos, químicos e físicos, é um aspecto importante para a saúde publica e para a qualidade dos produtos lácteos (WALSTRA et al., 2001).

Pelo seu elevado valor nutricional o leite constitui-se um excelente substrato para o desenvolvimento microbiano (HAYES; BOOR, 2001). A maior parte das contaminações presentes no leite recebido pela indústria tem origem na fazenda onde as principais fontes são o interior e exterior do úbere, o equipamento de ordenha e o ambiente (HARDING, 1999). Assim, o perfil microbiológico do leite cru é um importante indicador da sua qualidade e reflete a saúde da vaca, a higiene da ordenha e o sistema de armazenamento a que o leite foi submetido (BUENO et al., 2001).

As bactérias são os principais microrganismos contaminantes do leite e, quando produzido sob condições precárias de higiene pode conter patógenos como Salmonella e Listeria provenientes de contaminação fecal, Streptococcus proveniente de infecções do úbere e organismos deterioradores (HARDING, 1999). Vírus, fungos e leveduras têm uma participação reduzida, apesar de serem potencialmente importantes em algumas situações, (FONSECA; PEREIRA; CARVALHO, 1999).

O leite pode provocar infecções alimentares, quando possui microrganismos patogênicos ou intoxicações, quando nele estão presentes toxinas microbianas (WALSTRA et al, 2001). Algumas dessas toxinas são termorresistentes como, por exemplo, as produzidas por Staphylococcus aureus e Escherichia coli, permanecendo ativas mesmo após a pasteurização (OLIVEIRA; FONSECA; GERMANO, 1999).

O leite proveniente de vacas com mastite e com contagens elevadas de células somáticas (CCS) apresentam alterações na sua composição onde a caseína é o principal componente afetado (HARMON, 1999). Segundo Oliveira, Fonseca e Germano (1999), elevados níveis de CCS provocam conseqüências negativas na indústria como redução no rendimento na produção de lácteos e menor vida de prateleira dos produtos. 
De acordo com Mistry (2001) esporos de bactérias como Bacillus sibtilis e $B$. cereus presentes no leite são capazes de sobreviver à pasteurização e chegar ao produto final, conferindo sabor amargo ao iogurte.

Durante o desenvolvimento microbiano, ocorrem transformações na composição do leite através da ação de enzimas que hidrolisam a lactose, proteínas, gorduras, podendo gerar sabor e odor estranhos que alteram sua qualidade e diminuem sua aptidão para o processamento na indústria (WALSTRA et al, 2001). Como resultado da fermentação da lactose há produção de ácido lático e conseqüente acidificação do leite podendo ocasionar a coagulação da caseína e, assim limitar o uso do leite na indústria (GUIMARÃES, 2002).

A temperatura de armazenamento do leite é apontada por Laranja-Fonseca (1998) como o principal fator determinante da taxa de crescimento bacteriano. De acordo com Walstra et al. (2001), a redução da temperatura diminui da velocidade de praticamente todos os processos que ocorrem no interior das células bacterianas, prolongando 0 período de latência (fase em que as bactérias adaptam-se para metabolizar os nutrientes do meio) diminuindo, portanto o crescimento e a velocidade de fermentação.

Assim, o tipo de microrganismo predominante depende do tempo e da temperatura de armazenamento do leite (HARDING, 1999). Os microrganismos mesófilos (faixa ótima de crescimento entre 20 e $40^{\circ} \mathrm{C}$ ) predominam em situações em que há falhas na higiene e na refrigeração do leite. Por outro lado, o tempo prolongado de armazenamento em temperaturas de refrigeração favorece o crescimento e predomínio de bactéria psicrotróficas (capazes de crescer a temperaturas abaixo de $7^{\circ} \mathrm{C}$, independente da temperatura ótima de crescimento) (GUIMARÃES, 2002). Embora a grande maioria das bactérias psicrotróficas seja destruída pela pasteurização, com exceção das bactérias termodúricas, esse grupo apresenta a capacidade de produção de enzimas lipolíticas e proteolíticas termorresistentes que mantém sua atividade enzimática mesmo após o tratamento térmico (SANTOS; LARANJA, 2001).

As alterações dos componentes do leite, em função do crescimento dos psicrotróficos, limitam a vida de prateleira dos produtos lácteos devido ao aparecimento de alterações no sabor e no odor, além da redução do rendimento na produção de derivados (GUIMARÃES, 2002). A presença de lípase bacteriana provoca a quebra dos ácidos graxos de cadeia longa em cadeias mais curtas conferindo off-flavor com odor e 
sabor rancificados ao produto final. Elevados níveis de ácidos graxos livres e a presença de proteínas antibacterianas no leite podem inibir a ação do cultivo starter e a quebra das proteínas, provocar sinerese na fabricação do iogurte (HARDING, 1999).

Devido ao fato da qualidade das proteínas do leite influenciar diretamente a qualidade do iogurte, é desejável que a proteólise do leite cru seja mínima, situação que pode ser controlada com o armazenamento do leite a temperaturas suficientemente baixas para limitar a atividade das proteases microbianas ou nativas do leite (VARNAM; SUTHERLAND, 1994).

Assim, os cuidados com a qualidade do leite cru devem ter inicio ainda na fazenda e para uma melhor conservação deve ser resfriado o mais rapidamente possível após sua extração (WALSTRA et al. 2001). Hayes e Boor (2001) e Laranja-Fonseca (1998), recomendam o resfriamento do leite a temperatura de $4 \stackrel{\circ}{\circ}$ imediatamente após a ordenha como forma de inibir o crescimento de mesofilos e termófilos além de reduzir a degradação enzimática.

Segundo Harding (1999), o número de bactérias no leite aumenta rapidamente a temperaturas de armazenamento acima de $10{ }^{\circ} \mathrm{C}$ e a taxa de crescimento das bactérias contaminantes é virtualmente zero à temperaturas abaixo de $2^{\circ} \mathrm{C}$. $\mathrm{O}$ autor recomenda que em situações onde o leite é armazenado antes de ser pasteurizado ele deve ser mantido a temperaturas abaixo de $4^{\circ} \mathrm{C}$ para minimizar a deterioração e quando o período de armazenamento for muito longo, o resfriamento deve ser a $2 \stackrel{\circ}{\circ}$.

Além da contaminação microbiológica, a presença de contaminantes químicos no leite merece atenção. Os antibióticos utilizados para tratamento de enfermidades das vacas leiteiras, especialmente os antimastíticos, quando presentes no leite oferecem serio risco à saúde pública além afetar a atividade dos cultivos starter na indústria. De acordo com Heeschen e Harding (1999), o consumo de leite com resíduos de antibióticos podem provocar no organismo humano reações alérgicas, o surgimento de resistência bacteriana, além de algumas drogas terem atividade carcinogênica ou mutagênica.

$\mathrm{Na}$ produção de iogurte, os resíduos de antibióticos comprometem a associação simbiótica entre S. termophilus e L. bulgaricus, tornando mais lenta a produção de ácido láctico e conseqüentemente, maior tempo necessário para sua elaboração (TAMINE; ROBINSON, 1991). 
Outra contaminação química importante são os resíduos de detergentes e desinfetantes utilizados na higienização dos equipamentos devido a enxágüe insuficiente ou produtos químicos, provenientes da agricultura e absorvidos pela vaca através da alimentação (WALSTRA et al. 2001). A presença desses compostos no leite inibe o crescimento e a atividade dos cultivos starter além de alterar a morfologia das células bacterianas (TAMINE; ROBINSON, 1991).

Um aspecto importante em termos de saúde pública é a contaminação do leite com aflatoxina $M 1$, proveniente do metabolismo da aflatoxina B1 em vacas que tenham consumido alimentos contaminados. A aflatoxina B1 é um produto carcinogênico, formado durante o metabolismo secundário de Aspergillus flavus e Aspergillus parasiticus (FLOWERS et al., 1993; HEESCHEN; HARDING, 1999).

\subsubsection{Pasteurização}

O processo de pasteurização do leite consiste no tratamento térmico, utilizando temperaturas inferiores a $100 \stackrel{\circ}{\mathrm{C}}$, para redução da carga microbiana e eliminação completa dos microrganismos patogênicos (VEISSEYRE, 1988). Pela sua reconhecida eficiência no controle dos microrganismos transmissores de doenças, a pasteurização do leite é obrigatória pela legislação vigente e amplamente utilizada na indústria, constituindo-se, segundo Speer (1991), a base para os processamentos posteriores do leite na indústria de laticínios.

A pasteurização deve ter um efeito germicida superior a $99 \%$, além de eliminar totalmente os microrganismos patogênicos e alterar o mínimo possível os componentes do leite e suas características organolépticas (SPEER, 1991). No caso especifico da fabricação de iogurte, a pasteurização tem também a função de diminuir a competitividade com os microrganismos starter (STAFF, 2000).

A efetividade da pasteurização, no entanto, depende da temperatura aplicada e tempo de retenção (binômio tempo x temperatura), da carga microbiana inicial e da resistência dos microrganismos à destruição pela temperatura (TAMINE; ROBINSON, 1991; HAYES; BOOR, 2001).

De acordo com Speer (1991) a pasteurização do leite a 71-74 ํㅡ por 8-12 segundos (HTST), é a mais comumente utilizada pela indústria. Nessas condições são 
destruídos todos os microrganismos patogênicos, além de bolores, leveduras e a maioria das formas vegetativas das bactérias (WALSTRA et al., 2001).

Desde que não muito severo, o aquecimento do leite obtido pela pasteurização contribui para algumas mudanças desejáveis nas propriedades físico-químicas do leite para a fabricação de iogurte, como desnaturação das proteínas do lactossoro e formação de um gel mais estável (VEISSEYRE, 1988). Mystry (2001) cita que na prática existem várias combinações de tempo $\mathrm{x}$ temperatura possíveis para $\mathrm{o}$ tratamento do leite e da mistura base láctea e que a pasteurização a $85 \stackrel{\circ}{\mathrm{C}}$ por 30 minutos é a que permite os melhores resultados quanto à estabilidade do coágulo.

\subsubsection{Fermentação e Resfriamento/Quebra do Coágulo}

A etapa de fermentação é uma das mais importantes na fabricação do iogurte, pois é nela que são desenvolvidas as propriedades de acidez, aroma e viscosidade características do produto (STANLEY, 2000).

$\mathrm{O}$ baixo $\mathrm{pH}$ do iogurte é um inibidor eficaz para muitas bactérias, inclusive as patogênicas (MISTRY, 2001). Essa condição, no entanto é favorável para o crescimento de bolores e leveduras os quais em elevadas concentrações podem provocar transtornos digestivos ao consumidor (VARNAM; SUTHERLAND, 1995) e alterações no sabor a aroma do iogurte pela fermentação e produção de gás (STAFF, 2000).

Varnam e Sutherland (1995) afirmam que existe, a possibilidade de certos gêneros de patógenos resistirem a condições de $\mathrm{pH}$ baixo $(4,1)$ por alguns dias, quando presentes em elevadas concentrações, ou ainda a adaptação de certos microrganismos como Salmonela às condições ácidas do iogurte. Assim, o baixo pH nem sempre é suficiente para garantir a segurança do iogurte, sendo essencial todas a medidas higiênicas para evitar recontaminação do produto.

Devido ao fato de alguns atributos de qualidade do iogurte como textura, suavidade, viscosidade, aroma e sabor característicos serem resultado do desenvolvimento dos microrganismos starter, a manutenção da temperatura ideal para a fermentação e o acompanhamento da queda gradual do $\mathrm{pH}$ garantem ao produto final as características desejadas (STANLEY, 2000). 
A temperatura ideal para o desenvolvimento das bactérias termófilas utilizadas na fabricação do iogurte é de 40-45 ํㅡ (SPEER, 1998). Porém, de acordo com Tamine e Robinson (1991) é possível, a utilização de temperaturas mais baixas, até $30{ }^{\circ} \mathrm{C}$, prolongando, neste caso, o tempo de incubação para que seja atingido o pH desejado.

Depois de atingida a acidez ideal do iogurte a fermentação é interrompida e segundo Tamine e Robinson (1991), a refrigeração é um dos métodos mais empregados para controlar a atividade metabólica dos cultivos starter e suas enzimas, além de permitir maior estabilidade do coágulo e menores alterações durantes as etapas posteriores do processamento. Os autores recomendam que a temperatura deve atingir valores de $10 \stackrel{\circ}{C}$ ou menos, o mais rapidamente possível, pois a atividade dos microrganismos starter é reduzida a essa temperatura.

Staff (2000) cita que o momento de se interromper a fermentação depende de fatores como: $\mathrm{pH}$ final desejado, volume do tanque fermentado, método de refrigeração empregado (lento ou rápido) e /ou da eficiência da transmissão de calor no tanque de fermentação.

\subsubsection{Adição de Ingredientes e Envase}

Os manipuladores são considerados como uma das mais importantes fontes de contaminação dos alimentos (SOUZA, 2006). No momento da adição manual de ingredientes, durante o processamento do iogurte, é possível introduzir ao produto contaminações presentes no ambiente ou no manipulador caso não sejam tomados os devidos cuidados higiênicos.

Pertencem à flora cutânea normal do homem microrganismos como micrococos, estafilococos, pseudomonas, germes anaeróbicos, leveduras, entre outros (SILVA JUNIOR, 2002). De acordo com Evangelista (2001) e Germano (2003a), microrganismos como Staphylococcus aureus, são encontrados habitualmente nas fossas nasais, mucosas e pele dos indivíduos e Escherichia coli, estão comumente presentes nas mãos de manipuladores. Tais microrganismos podem contaminar os produtos através de hábitos de higiene inadequados durante a adição de ingredientes e envase.

De acordo com Walstra et al. (2001), o controle da contaminação durante o envase é essencial para a conservação do produto devendo ser considerados os mesmos 
padrões de higiene do ambiente e manipuladores praticados em outras etapas da produção, especialmente se o tratamento térmico ocorre antes do envase.

Segundo Germano (2003a), a utilização de procedimentos operacionais padronizados e de boas práticas de fabricação, além de hábitos pessoais dos manipuladores são alguns dos aspectos que devem ser observados para que estes não se constituam em fontes de contaminação alimentar.

Outro aspecto importante a ser observado no processamento de iogurte diz respeito às quantidades utilizadas de determinados ingredientes, as quais devem respeitar os limites máximos permitidos pela legislação. Ingredientes como estabilizantes, edulcorantes, quando em concentrações elevadas podem tornar-se tóxicos colocando em risco a saúde do consumidor, além de apresentar efeitos inibidores sobre os microrganismos starter e /ou alterar o aspecto e palatabilidade do iogurte (STAFF, 2000).

\subsubsection{Recepção de Ingredientes e Embalagens}

A obtenção de ingredientes com qualidade assegurada, provenientes de empresas idôneas e que sejam mantidos em condições adequadas de armazenamento, são requisitos indispensáveis para a qualidade do produto final (GÓES et al., 2001; EHIRI; MORRIS; McEWEN, 1995). Tais requisitos fazem da parte da etapa de recepção de ingredientes um importante ponto crítico na produção de alimentos (FORSYTHE, 2002).

De acordo com Rosenthal (1991), o primeiro passo para a garantia da qualidade de qualquer produto é o estabelecimento, de forma clara, das especificações para a recepção da matéria-prima, com relação à composição, condições de transporte, presença de contaminações, entre outros, os quais devem se constituir nos limites críticos para esta etapa.

Ainda sob esse aspecto, Mortimore e Wallace (1998) recomendam que para a definição das especificações das matérias-primas e outros materiais utilizados no processamento deve-se levar em consideração não somente a qualidade como também a segurança alimentar, e os limites de tolerância devem ser estabelecidos em comum acordo com o fornecedor.

Segundo Hayes (1995), a inspeção das matérias primas deve ser feita no momento de seu recebimento, evitando o armazenamento de qualquer produto com defeito, ou 
seja, com possíveis infestações de pragas, com danos físicos e contaminações. Caso o material recebido esteja fora dos padrões, ele deve ser manuseado de acordo com um plano de ação previamente definido em conjunto com o fornecedor. Ainda segundo o autor, é importante o monitoramento e rotação dos estoques de matérias-primas, evitando sua deterioração durante o armazenamento.

Especialmente para a produção de iogurte, Staff (2000) recomenda atenção para a presença de antibióticos, bacteriófagos, resíduos de detergentes, desinfetantes ou qualquer outra substancia nas matérias-primas que possam inibir o desenvolvimento do cultivo starter.

Varnam e Sutherland (1996), também enfatizam a importância da boa qualidade dos ingredientes utilizados na elaboração de iogurtes, principalmente daqueles adicionados após a pasteurização. Dadas as condições de $\mathrm{pH}$ baixo do iogurte, desfavorável à maioria dos microrganismos, os principais causadores de alterações são bolores e leveduras, ácido tolerantes e capazes de realizar fermentação com formação de gás e eventualmente provocar abaulamento embalagens durante 0 período de armazenamento. Segundo Mistry (2001), a principal fonte desse tipo de contaminação no produto acabado, são os purês de frutas.

Com respeito às embalagens, devem ser higiênicas, isentas de odores e constituídas de material inerte, que não reaja com o produto (HAYES, 1995). No caso especifico do iogurte, devem ser resistentes aos ácidos, além de evitar perdas das substancias voláteis responsáveis pelo aroma do produto e impermeáveis ao oxigênio, já que este favorece o crescimento de bolores e leveduras (TAMINE; ROBINSON, 1991).

Os materiais de envase em si não são uma fonte significativa de microrganismos, devido às elevadas temperaturas atingidas na sua fabricação, além de não serem substratos adequados para os microrganismos. No entanto, boas práticas de higiene durante a produção, transporte e armazenamento do material de envase são recomendáveis para evitar contaminações posteriores, principalmente com microrganismos patogênicos e bactérias capazes de se desenvolver durante o período de armazenamento do produto acabado (WALSTRA et al. 2001).

Existem diversos tipos de embalagens para os produtos lácteos e dentro da categoria dos plásticos o polietileno é o principal material utilizado pela indústria. As garrafas rígidas, quando utilizadas, são geralmente fabricadas por terceiros e 
posteriormente enviadas ao laticínio (ROSENTHAL, 1991). Assim, Hayes (1995) recomenda que elas sejam armazenadas em suas embalagens originais até o momento do uso e que os materiais de embalagens que foram somente utilizados parcialmente sejam fechadas com cuidado e armazenadas até o próximo envase.

Ehiri, Morris e McEwen (1995) e Mortimore e Wallace (1998), apontam as auditorias aos fornecedores como um elemento importante no monitoramento deste ponto crítico, pois possibilitam que muitos problemas identificados na recepção sejam evitados, além de fornecer subsídios para avaliação dos fornecedores atuais e permitir a seleção de novos.

\subsubsection{Armazenamento do Produto Acabado e Expedição}

De acordo com Rosenthal (1991) o objetivo da etapa de armazenamento deve ser manter a qualidade que o produto possuía no momento em que foi embalado, sendo que o fator crítico neste caso é a temperatura. Ainda segundo o autor, aumentos na temperatura, mesmo que por tempo limitado, reduzem a vida de prateleira de produtos lácteos como o iogurte.

As variações de temperatura durante o período de conservação produzem modificações na textura e viscosidade, originam a separação do soro e favorecem o desenvolvimento de microrganismos alterantes e patogênicos, possivelmente presentes. Além disso, a exposição a temperaturas elevadas, acelera as reações bioquímicas como a oxidação da gordura, aumenta a hidratação das proteínas contidas no iogurte, produz a desidratação da superfície do produto e modifica a coloração das frutas (STAFF, 2000).

De acordo com Tamine e Robinson (1991) a refrigeração do iogurte deve ser feita a temperaturas inferiores a $10^{\circ} \mathrm{C}$, para reduzir as reações provenientes da atividade metabólica dos microrganismos starter e de possíveis contaminantes que resistem ao tratamento térmico e fermentativo ou ainda que contaminem o produto após sua elaboração. Staff (2000) recomenda que durante todo o período de armazenamento do iogurte, a temperatura deve manter-se entre 2 e $5 \stackrel{\circ}{\circ}$ e nunca ultrapassar os $10 \stackrel{\circ}{\circ}$ nas etapas intermediarias da cadeia de distribuição como transporte de paletes, descarga, e geladeiras expositoras nos pontos de venda. 
Para que a temperatura na câmara fria seja mantida constante é importante assegurar a circulação de ar no seu interior (TAMINE; ROBINSON, 1991) e evitar que as portas permaneçam abertas desnecessariamente durante o período de armazenamento (SPEER, 1991). Rosenthal (1991), acrescenta ainda como aspectos importantes o correto manejo dos estoques quanto ao prazo de validade dos produtos e a limpeza no interior da câmara que deve permanecer seca, limpa e livre de pragas.

De acordo com Hayes (1995), durante o transporte, os produtos lácteos devem ser expostos o mínimo possível às condições externas e protegidos do contato com qualquer tipo de sujidade e odores estranhos. Para garantir as condições higiênicas necessárias o autor recomenda que sejam realizadas inspeções freqüentes no interior dos baús.

\subsubsection{Higienização dos Equipamentos}

A presença de resíduos orgânicos e minerais aderidos às superfícies internas dos equipamentos possibilita o desenvolvimento microbiano, levando à contaminação do produto durante o processamento. Assim, segundo Speer (1998) a qualidade higiênica do produto acabado depende consideravelmente da limpeza e desinfecção de máquinas, equipamentos, utensílios e instalações.

O tipo de resíduo presente nas superfícies internas dos equipamentos varia de acordo com a composição do alimento e a natureza do processo ao qual ele foi submetido. Alguns constituintes dos alimentos sofrem alterações químicas com 0 aquecimento, tornando mais difícil a limpeza (HAYES, 1995).

No caso específico da indústria de laticínios, as sujidades encontradas consistem principalmente em restos de produto aderido e partículas de componentes do leite como gordura, proteína e minerais. Juntamente a esses resíduos podem estar associados diversos tipos de microrganismos como coliformes, agentes deterioradores, bactérias proteolíticas, fungos, bolores, bactérias ácido láticas e microrganismos patogênicos. (SPEER, 1998).

$\mathrm{Na}$ escolha do procedimento de limpeza alguns aspectos devem ser considerados como natureza da sujidade ou contaminação, tipo de superfície a ser limpa, agente de limpeza, grau de dureza da água, além do padrão de limpeza desejado (ICMSF; 1991). Definido o método, a eficiência da limpeza dependerá de fatores como temperatura, 
concentração e tempo de exposição da solução de limpeza e ação mecânica empregada (FUJIHARA; SYLVIO, 2002). 


\section{OBJETIVOS}

\subsection{Objetivo geral}

O objetivo geral do presente trabalho foi elaborar e implantar o sistema APPCC na linha de produção de iogurte em uma indústria de laticínio localizada no Estado de São Paulo.

\subsection{Objetivos específicos}

Tendo em vista os aspectos mencionados anteriormente, foram objetivos específicos do presente trabalho:

a) Mensurar os custos totais de elaboração e implantação do sistema APPCC;

b) Avaliar a relação custo-benefício resultante da implantação do sistema, com relação:

- À qualidade intrínseca do produto acabado, verificada através de parâmetros microbiológicos;

- Ao nível de perda de embalagens durante o processamento. 


\section{MATERIAL E MÉTODOS}

\section{1 Época e local de estudo}

O presente estudo foi desenvolvido no período de Agosto de 2006 a Agosto de 2007, em uma indústria de laticínios localizada no município de São Carlos, Estado de São Paulo, controlada pelo Serviço de Inspeção Federal do Ministério da Agricultura, Pecuária e Abastecimento (SIF/MAPA).

A planta processava aproximadamente 15 mil litros de leite por dia, captados de produtores da região e destinados à fabricação de iogurtes, leite achocolatado e creme de leite fresco. A área construída do laticínio compreendia sala de processamento, sala de envase, almoxarifado para embalagens e ingredientes, câmara fria para estocagem do produto acabado e laboratório onde eram realizadas análises físico-químicas e microbiológicas das matérias-primas e produto acabado (Anexo A).

Os produtos eram comercializados no mercado varejista local, em outras cidades do Estado e também como "marca própria" para algumas redes varejistas de supermercados.

\subsection{Aplicação do sistema APPCC}

O sistema APPCC foi desenvolvido para a linha de produção de iogurtes. Sua elaboração e implementação foram baseadas nas etapas seqüenciais propostas por SENAI (2000), Cezari e Nascimento (1995) e Corlett (1998) e são apresentadas a seguir:

\subsubsection{Procedimentos Preliminares}

\subsubsection{Comprometimento da gerência}

Programou-se uma reunião com o responsável pela direção do laticínio, com o objetivo de apresentar uma proposta para a realização do projeto. $\mathrm{Na}$ ocasião, foram discutidos os objetivos pretendidos, as etapas a serem cumpridas e as responsabilidades sobre os custos envolvidos, além de esclarecer sobre os possíveis benefícios e as 
dificuldades relativos ao programa a ser implantado, como recomendado por Mortimore e Wallace (1998).

O laticínio demonstrou interesse na implantação do sistema não só por reconhecer sua importância para a melhoria da qualidade de seus produtos como também pela necessidade de adequação às exigências legais requeridas pelo Ministério da Agricultura através do Serviço de Inspeção Federal - SIF e exigências de mercado por parte de alguns clientes.

Com o aceite do proprietário, e a obtenção da garantia de seu comprometimento com o projeto, foram asseguradas as condições necessárias para a execução do trabalho.

\subsubsection{Diagnóstico dos programas de pré-requisitos existentes}

Foi realizada uma avaliação das condições higiênico-sanitárias existentes no laticínio e do grau de adequação aos programas de Boas Práticas de Fabricação - BPF e Procedimentos - Padrão de Higiene Operacional - PPHO, pré-requisitos para o APPCC. Tais programas são essenciais, pois além de criarem as condições necessárias para o perfeito funcionamento do plano APPCC (WALLACE; WILLIAMS, 2001), em muitas situações estabelecem ou constituem medidas preventivas para o controle dos perigos (HAJDENWURCELL, 2002), simplificando o plano e garantindo sua eficiência com relação à segurança alimentar (SENAI, 2000).

Para orientar a avaliação, foi utilizada a "Lista de Verificação de Boas Práticas de Fabricação em Estabelecimentos Produtores / Industrializadores de Alimentos" editada pela ANVISA - Agencia Nacional de Vigilância Sanitária do Ministério da Saúde através da Resolução RDC 275 de 23/10/2002 (BRASIL, 2002).

Com o resultado do diagnóstico, foi elaborado um relatório contendo as não conformidades encontradas e apresentado aos responsáveis pelo laticínio para os ajustes necessários.

\subsubsection{Capacitação técnica - Treinamento em BPF}

Para a identificação dos hábitos higiênicos dos manipuladores e do grau de conhecimento das Boas Práticas de Fabricação, foi traçado um diagnóstico inicial com informações colhidas da Lista de Verificação (BRASIL, 2002) e da aplicação de um questionário individual (Anexo B). 
Com base nos resultados obtidos, foi elaborado um programa de treinamento que se estendeu a todos os funcionários do laticínio, desde os responsáveis pela produção até a expedição de produto acabado, incluindo também o pessoal do setor administrativo.

O treinamento foi realizado na forma de palestras expositivas, utilizando projetor multimídia como material de apoio (GERMANO, 2003b) e foram abordados temas relacionados à produção de alimentos seguros e boas práticas de manipulação, tomandose como base o manual elaborado por Hazelwood e McLean (1994).

Como método facilitador do aprendizado, foram utilizadas figuras ilustrativas e fotos das condições reais do laticínio. Buscou-se nesse momento não somente a transferência de conhecimentos técnicos como também provocar uma mudança comportamental dos participantes através da conscientização de cada um quanto ao seu papel no processo produtivo, como recomendado por Hajdenwurcell (2002) e McAloon (2003). Foi estimulado o debate com a troca de conhecimentos trazidos de experiências anteriores e a formação de uma consciência crítica de acordo com a didática proposta por Freire (2006).

O programa de capacitação técnica foi aplicado também a todos os novos funcionários no momento da admissão.

\subsubsection{Formação da equipe}

A equipe responsável pelo plano APPCC foi constituída por funcionários envolvidos nas atividades diárias de produção e coordenada pelo gerente do laticínio, que reunia as condições ideais para essa tarefa como: experiência previa no sistema APPCC, conhecimento técnico do processo de fabricação de lácteos, posição de liderança sobre os demais funcionários além de acesso fácil à diretoria da empresa (MAYES, 1994; HAJDENWURCELL; 2002).

\subsubsection{Descrição do produto}

O primeiro passo foi o conhecimento detalhado do produto fabricado através de suas características físico-químicas e microbiológicas, dos ingredientes que participavam de sua composição, material de embalagem, especificações quanto ao armazenamento e transporte e também uso pretendido. 
4.2.1.6 Elaboração e validação do fluxograma de processo

O propósito desta etapa foi elaborar de forma simples e clara um fluxograma que permitisse reconhecer todas as etapas relacionadas ao processo de produção (CEZARI; NASCIMENTO, 1995), além de servir de apoio para a identificação dos perigos e medidas preventivas. Foram identificados também os equipamentos envolvidos no processamento e suas características de funcionamento (temperatura, pressão, entre outros).

A metodologia utilizada foi a observação visual do processo de fabricação desde a chegada do leite cru e demais ingredientes até o envase, o armazenamento e a expedição do produto acabado.

Depois de elaborado, o fluxograma foi discutido e avaliado in loco com o gerente do laticínio para a confirmação de cada etapa e realização dos ajustes necessários, garantindo sua correspondência com a realidade.

\subsubsection{Treinamento da equipe APPCC}

O treinamento direcionado ao APPCC foi realizado para todos os funcionários envolvidos na produção e expedição do laticínio. A metodologia para preparação das palestras foi a mesma utilizada anteriormente para BPF e nesse momento foi feita a apresentação do plano, seus princípios, os objetivos a serem atingidos e as etapas para sua aplicação.

\subsubsection{Aplicação dos Princípios do APPCC}

Principio 1. Estudo dos perigos envolvidos na fabricação do iogurte e medidas preventivas

Com base na literatura especializada e com o conhecimento das matérias primas utilizadas e do fluxograma de processo, foi possível realizar um estudo das possíveis contaminações (perigos) de natureza física, química e microbiológica presentes na fabricação do iogurte, além de medidas preventivas.

Embora o sistema APPCC tenha sido originalmente desenvolvido para assegurar a inocuidade dos alimentos, de forma a preservar a saúde do consumidor, na elaboração deste trabalho adotamos uma abordagem mais ampla, baseada no conceito de perigo proposto pelo Ministério da Agricultura, Pecuária e Abastecimento através da portaria no 46 de 10/02/1998 (BRASIL, 1998). Assim, considerou-se não somente os fatores que 
dizem respeito à inocuidade como também aqueles que ocasionam "perda da qualidade e da integridade econômica do produto" gerando não conformidades com o padrão de identidade estabelecido pelo laticínio.

Principio 2. Identificação dos pontos críticos de controle (PCC)

Com o auxílio da árvore decisória, foram identificados, no fluxograma de processo, os pontos onde poderiam ocorrer os perigos, que deveriam ser eliminados, prevenidos ou reduzidos a níveis aceitáveis.

Principio 3. Determinação dos limites críticos

Para cada ponto crítico foi estabelecido um limite crítico, associado a valores como binômio tempo x temperatura, $\mathrm{pH}$, temperatura, acidez, garantido a segurança do processo. Seguindo recomendação de Cezari e Nascimento (1995), em alguns casos foram definidos limites de segurança, evitando assim que os limites críticos fossem ultrapassados. Os limites aqui estabelecidos foram obtidos da literatura especializada, legislação vigente e experiência prática da equipe.

\section{Principio 4. Estabelecimento dos procedimentos de monitoramento}

Foram criadas formas de controle para cada ponto crítico, através de observações visuais, mensurações, análises laboratoriais, além da freqüência com que elas seriam realizadas e o funcionário responsável pela operação. A escolha do procedimento de monitoramento considerou a facilidade e rapidez no fornecimento dos resultados, para que os ajustes necessários fossem realizados de forma ágil, não comprometendo o ritmo do processamento.

A aferição e calibração dos equipamentos utilizados no monitoramento dos PCCs mereceram especial atenção nesta fase.

Principio 5. Estabelecimento de ações corretivas

Foram previstas ações corretivas para o caso dos limites críticos serem ultrapassados e saírem de controle 
Princípio 6. Estabelecimento dos procedimentos de registros

Todos os monitoramentos dos PCCs foram registrados em planilhas de controle e tentou-se aproveitar, sempre que possível, as formas de registros existentes na rotina do laticínio, como recomendado por Mortimore e Wallace (1998), fazendo-se apenas as alterações necessárias com espaços para ações corretivas e assinatura do responsável. O objetivo foi evitar um número elevado de documentos e gasto excessivo de tempo para preenchimento.

A elaboração do plano APPCC foi documentada compondo o "Manual de APPCC para fabricação de iogurte", contendo de forma seqüencial as etapas seguidas ao longo do trabalho e apresentados como se segue:

- Apresentação da empresa

- Descrição do produto e uso pretendido

- Identidade do produto

- Descrição dos ingredientes e tipo de embalagem

- Estudo dos perigos

- Fluxograma de produção com identificação dos PCCs

- Descrição das etapas do processo

- Plano de controle dos PCCs

- Resumo do plano

O manual permitiu uma visão geral do plano APPCC e foi utilizado como material de apoio nas auditorias internas e naquelas realizadas por clientes.

Princípio 7. Estabelecimento dos procedimentos de verificação

Depois de implantado, foram definidas formas para verificação do correto funcionamento do plano APPCC. Os procedimentos utilizados foram: revisão do fluxograma de processo, revisão dos limites críticos, revisão dos registros de monitoramento dos PCCs, análise laboratorial do produto acabado e análise dos desvios dos limites críticos encontrados no período.

A freqüência estabelecida inicialmente para as verificações foi de 30 dias, porém a previsão é que esse intervalo seja ampliado à medida que o plano se consolide. 


\subsection{Apuração dos custos do sistema APPCC}

Foram apurados todos os custos envolvidos na adequação aos programas prérequisitos (BPF, PPHO) e implantação do sistema APPCC que compreendeu o período de agosto de 2006 a agosto de 2007, sendo os valores expressos em reais (moeda corrente).

O método de apropriação de custos utilizado foi o custeio por absorção, que consiste na contabilização de todos os gastos diretos e indiretos envolvidos com 0 APPCC, como definido por Figueiredo (2001).

Os gastos apurados foram classificados em investimentos - gastos que serão utilizados ao longo do tempo e custeio - gastos realizados no período.

Um estudo prévio na literatura apontou uma série de itens que normalmente compõem os custos do sistema APPCC em indústrias de alimentos (ROBERTO; BRANDÃO; da SILVA, 2006; BATA et al., 2006; HENSON; HOLT; NORTHEN, 1999; BUCHWEITZ, 2001) e que serviram de guia para a execução deste trabalho. Para a composição dos custos foram considerados os seguintes itens:

- Suporte técnico: despesas com a contratação de um serviço de consultoria para elaboração do plano APPCC e coordenação do processo de implantação. Foram considerados os valores de mercado, obtidos através de cotação junto a uma empresa do ramo;

- Funcionário para elaboração do plano: foi considerado o custo/hora do chefe da equipe APPCC para participar da elaboração do plano;

- Treinamento dos funcionários: considerou-se o custo de mercado de um profissional técnico em APPCC e BPF para as palestras de treinamento e capacitação dos funcionários realizadas durante o projeto;

- Aquisição de equipamentos: foram apuradas todas as compras de equipamentos necessários especificamente aos programas pré-requisitos e APPCC. Neste item, incluem-se também os custos de mão de obra e materiais para instalação dos equipamentos; 
- Análises laboratoriais: foram apurados os custos com material e laboratório para a realização das análises laboratoriais envolvidas no monitoramento e verificação do APPCC;

- Mudanças estruturais na planta: envolveram os custos de possíveis alterações estruturais ou reformas necessárias para adequação aos programas pré-requisitos e para o APPCC. Estão aqui computados os gastos com materiais e mão de obra;

- Tempo gasto no monitoramento e preenchimento de registros dos PCCs: considerou-se o número de horas gastas para monitoramento dos PCCs e preenchimento das planilhas de controle. Os cálculos foram baseados no custo/hora do funcionário que realizou a operação sendo considerados além do salário nominal, os encargos sociais como férias, 13ํㅗaário, INSS e FGTS;

- Verificação e avaliação do sistema APPCC: compreendeu o número de horas gastas na verificação da eficiência do sistema e na análise dos registros de monitoramento. Os cálculos foram baseados no custo/hora do funcionário que realizou a operação sendo considerados além do salário nominal, os encargos sociais como férias, 13ํㅗário, INSS, férias e FGTS.

\subsection{Avaliação dos benefícios do sistema APPCC}

$\mathrm{Na}$ literatura especializada são enumerados vários benefícios diretos e indiretos obtidos a partir da implantação do APPCC. Neste trabalho estudamos dois dos fatores apontados em pesquisa realizada por Henson, Holt e Northen (1999), junto a plantas de processamento de lácteos, como benefícios obtidos com o sistema: redução de perdas e redução da contagem microbiológica do produto acabado.

\subsubsection{Perdas de embalagens durante a produção}

Foram avaliadas as perdas de embalagens - garrafas plásticas, tampas e rótulos ocorridas durante o processo de fabricação do iogurte. O total de embalagens perdidas compreendeu a soma das perdas ocorridas durante o processo de rotulagem das garrafas, o envase e a embalagem secundária. 
Inicialmente foram estabelecidos quais os motivos que levariam uma embalagem a ser descartada: embalagens amassadas ou que viessem a cair no chão, embalagens fora das especificações previamente estabelecidas (tamanho, peso, formato, cor), presença de rebarbas ou contaminações físicas visíveis, vazamento após o enchimento e selagem ou refugo pelos equipamentos de rotulagem ou de envase.

A decisão para descarte das embalagens coube aos operadores durante 0 processamento, através de análise visual, sendo o material refugado armazenado em sacos plásticos, e posteriormente separado por tipo. A apuração do número de tampas, rótulos e garrafas perdidas foi feita através de contagem após o término de processamento, e a percentagem de perdas foi calculada com relação ao total de unidades que saíram do estoque.

A apuração das perdas foi realizada nos meses de Janeiro a Agosto, fornecendo dados para análise comparativa da situação anterior e posterior à instalação do sistema APPCC.

\subsubsection{Qualidade microbiológica do produto acabado}

A qualidade microbiológica do produto acabado foi avaliada através da determinação do número de ufc/g de bolores e leveduras e de coliformes totais e fecais, de acordo com as técnicas preconizadas pelo Laboratório Nacional de Referência Animal - LANARA do Ministério da Agricultura (LANARA, 1981). Foram utilizados os resultados das análises de rotina do produto acabado realizadas no laboratório do laticínio referentes ao período de Janeiro a Agosto de 2007.

\subsection{Análise Estatística}

Os resultados obtidos nas análises microbiológicas foram convertidos em log (ufc/g), com a finalidade de eliminar influências de resultados discrepantes. Juntamente com o percentual de perdas de embalagens foram submetidos à análise de variância, para a verificação de diferenças estatisticamente significativas entre o período anterior e posterior ao APPCC. Para a comparação entre as médias, quando aplicável, empregou- 
se o teste de Tukey, adotando-se, como nível de rejeição, $\alpha=0,05$ (GACULA; SINGH, 1984). 


\section{RESULTADOS E DISCUSSÃO}

\subsection{Adequação aos programas pré-requisitos}

No diagnóstico das condições iniciais do laticínio, a aplicação da Lista de Verificação de BPF (BRASIL, 2002) identificou atendimento a 70,7\% dos itens analisados (Tabela 1).

Tabela 1 - Resultado da aplicação da Lista de Verificação para Boas Práticas de Fabricação (BPF) no laticínio

\begin{tabular}{lccc}
\hline Aspectos analisados & $\begin{array}{c}\text { Total de itens } \\
\text { analisados }\end{array}$ & $\begin{array}{c}\text { No. Itens } \\
\text { conformes }\end{array}$ & $\begin{array}{c}\text { Conformidades } \\
\%\end{array}$ \\
\hline Edificações e Instalações & 70 & 56 & 80,0 \\
Equipamentos e utensílios & 21 & 16 & 76,2 \\
Manipuladores & 14 & 12 & 85,7 \\
Produção e transporte do & 32 & 20 & 62,5 \\
alimento & 13 & & \\
Documentação & $\mathbf{1 5 0}$ & $\mathbf{1 0 6}$ & $\mathbf{7 0 , 7}$ \\
\hline Total & & & \\
\hline
\end{tabular}

As não conformidades encontradas com este levantamento preliminar (Tabela 2) permitiram verificar que as condições básicas para implantação do APPCC ainda não estavam estabelecidas.

Coube à equipe APPCC coordenar os ajustes aos programas pré-requisito, etapa esta que compreendeu os meses de Agosto a Dezembro de 2006. 
Tabela 2 - Não conformidades com a Lista de Verificação para Boas Práticas de Fabricação (BPF) aplicada no laticínio.

\begin{tabular}{|c|c|}
\hline Item & Não conformidades \\
\hline $\begin{array}{l}\text { Edificações e } \\
\text { instalações }\end{array}$ & $\begin{array}{l}\text { - Resíduos do tratamento de efluentes exposto ao ambiente e com acúmulo } \\
\text { de moscas } \\
\text { - Porta externa da entrada principal sem fechamento automático } \\
\text { - Falta de tela contra entrada de insetos na janela do almoxarifado } \\
\text { - Torneiras dos lavatórios dos sanitários sem acionamento automático } \\
\text { - Ausência de registros da higienização das instalações } \\
\text { - Ausência de identificação adequada dos produtos químicos de } \\
\text { higienização e orientação do correto manuseio dos mesmos } \\
\text { - Ausência de responsável capacitado para limpeza do reservatório de água } \\
\text { e registro da higienização do mesmo } \\
\text { - Ausência de área adequada para estocagem de resíduos (lixo) } \\
\text { - Ausência de porta na sala de material de limpeza } \\
\text { - Armazenamento inadequado de ingredientes - incidência de sol sobre as } \\
\text { embalagens }\end{array}$ \\
\hline $\begin{array}{l}\text { Equipamentos e } \\
\text { utensílios }\end{array}$ & $\begin{array}{l}\text { - Ausência de registros de manutenções preventivas para equipamentos e } \\
\text { máquinas } \\
\text { - Ausência de responsável comprovadamente capacitado para higienização } \\
\text { dos equipamentos e registros da mesma }\end{array}$ \\
\hline Manipuladores & $\begin{array}{l}\text { - Falhas no asseio pessoal - Boas Práticas de Fabricação } \\
\text { - Falhas nos hábitos de higiene durante o processamento } \\
\text { - Ausência de programa de capacitação contínua em BPF e registros dos } \\
\text { mesmos }\end{array}$ \\
\hline $\begin{array}{l}\text { Produção e } \\
\text { transporte do } \\
\text { alimento }\end{array}$ & $\begin{array}{l}\text { - Ausência de inspeção de matérias-primas, ingredientes e embalagens no } \\
\text { momento da recepção dos mesmos } \\
\text { - Falhas no armazenamento higiênico e organizado de embalagens e } \\
\text { ingredientes } \\
\text { - Falhas no controle e acesso de pessoal de forma higiênica na área de } \\
\text { produção } \\
\text { - Falta de controle e registros da temperatura na câmara fria } \\
\text { - Falhas na identificação e armazenamento de produtos vencidos e/ou } \\
\text { avariados } \\
\text { - Ausência de plano de amostragem para análise laboratorial do produto } \\
\text { acabado } \\
\text { - Transporte do produto acabado em temperatura inadequada, colocando } \\
\text { em risco a integridade do produto }\end{array}$ \\
\hline Documentação & $\begin{array}{l}\text { - Ausência de Manual de Boas Práticas de Fabricação } \\
\text { - Ausência de procedimentos descritos para higienização dos equipamentos } \\
\text { e instalações e registros de sua execução } \\
\text { - Ausência de procedimentos descritos para higiene e saúde dos } \\
\text { manipuladores e registros de sua execução } \\
\text { - Ausência de procedimentos descritos para manutenção preventiva e } \\
\text { calibração de equipamentos e registros de sua execução }\end{array}$ \\
\hline
\end{tabular}




\section{Descrição dos Procedimentos de Higienização}

A fase inicial do trabalho foi destinada à descrição de todos os procedimentos de higienização executados no laticínio, criando protocolos de limpeza e desinfecção de equipamentos, ambiente e pessoal.

Foram realizadas várias visitas ao laticínio para acompanhamento visual da rotina de higienização dos equipamentos e instalações, além de diversas reuniões com o gerente. As informações fornecidas foram complementadas com dados da literatura especializada e recomendações dos fabricantes dos produtos químicos.

Os procedimentos foram descritos de forma detalhada e em formulários padronizados designados "Instruções de Trabalho" contendo informações como: tipo de produto utilizado, concentração, temperatura, forma de utilização, freqüência, funcionário responsável e a seqüência de passos da operação (ANEXO C). As Instruções de Trabalho para higienização contemplaram os seguintes aspectos:

- Higiene das Instalações

- Higiene pessoal e saúde dos manipuladores

- Recepção, armazenamento e manuseio de agentes químicos tóxicos

- Controle da potabilidade da água

- Superfícies de contato com o produto

O conjunto das instruções de trabalho para higienização resultou no Plano de Procedimento Padrão de Higiene Operacional (PPHO), elaborado de acordo com as recomendações da Resolução no 10 de 28/05/2003 do Ministério da Agricultura Pecuária e Abastecimento - MAPA (BRASIL, 2003), e assim estruturado: objetivos, campo de aplicação, responsabilidades, descrição dos procedimentos, monitorização, ações corretivas e registros.

\subsection{Treinamento dos manipuladores}

\subsubsection{Perfil dos Funcionários}

Estavam envolvidos diretamente com a produção 26 funcionários, divididos em três turnos de trabalho, sendo um gerente geral e dois laboratoristas, responsáveis pelo 
controle de qualidade, 18 funcionários encarregados do processamento e envase, três para expedição do produto acabado e dois encarregados da manutenção.

Em decorrência da rotatividade de funcionários, durante a execução do trabalho, passaram pelo treinamento 50 pessoas. Dados obtidos dos questionários mostram que a maioria deles trabalhava no laticínio a menos de um mês e não possuía experiência anterior. Verificou-se que apesar da maioria afirmar saber o que é contaminação alimentar e já ter ouvido falar em BPF, nunca havia recebido treinamento sobre o tema ou mesmo algum treinamento especifico sobre o trabalho que realizaria ao ingressar no laticínio. Tratava-se, portanto de um grupo formado recentemente sem experiência prática nas atividades desenvolvidas no laticínio e sem treinamento adequado.

Esses resultados justificam as falhas comportamentais encontradas no diagnóstico inicial com relação à higiene, reforçando a necessidade de um programa de treinamento.

\subsubsection{Reuniões de Treinamento}

Foram organizadas várias reuniões, sendo que a primeira delas contou com a presença de todos os funcionários do laticínio, inclusive aqueles ligados à administração Nela foram abordados conceitos básicos sobre BPF e segurança alimentar.

A primeira parte do treinamento foi expositiva, sendo definidos alguns conceitos sobre higiene, sua aplicação à produção de lácteos e a importância da busca pela qualidade. Em seguida, foram estimuladas discussões, focando as condições específicas do laticínio, e colocações de opiniões por parte dos ouvintes, como sugerido por Fernandez (1998), citado por Bellizi et al. (2005).

De acordo com a mesma metodologia, foram programadas mais duas reuniões destinadas à apresentação do programa de higienização (PPHO) e do plano APPCC. Os temas das reuniões estão expostos na Tabela 3. 
Tabela 3 - Temas e sub temas das reuniões de treinamento em BPF${ }^{1}, \mathrm{PPHO}^{2}$ e APPCC 3 aos funcionários do laticínio.

\begin{tabular}{|c|c|}
\hline Temas & Sub temas \\
\hline BPF & $\begin{array}{l}\text { 1- Definição de cadeia produtiva - da fazenda ao consumidor final } \\
\text { 2- Definição de alimentos seguros e contaminação } \\
\text { 3- Tipos de contaminação } \\
\text { 4- Importância da contaminação microbiológica } \\
\text { 5- Definição e sintomas das doenças veiculadas por alimentos - DVAs } \\
\text { 6- Condiç̃es ideais para o desenvolvimento de microrganismos } \\
\text { 7- Contaminação por microrganismos - eliminar, inibir, evitar } \\
\text { 8- Definição de Boas Práticas de Fabricação - BPF } \\
\text { 9- Onde são aplicados os princípios das BPF: higiene pessoal, } \\
\text { ambiente, equipamentos } \\
\text { 10-Hábitos corretos para a manipulação dos alimentos } \\
\text { 11-Vantagens das BPF: segurança alimentar, maior vida de prateleira, } \\
\text { redução de perdas, melhor ambiente de trabalho, consumidores } \\
\text { satisfeitos } \\
\text { 12-Necessidade de mudança de comportamento e do comprometimento } \\
\text { de todos os funcionários }\end{array}$ \\
\hline PPHO & $\begin{array}{l}\text { 1- Definição de PPHO / Instruções de Trabalho } \\
\text { 2- Importância da higienização - como evitar contaminações } \\
\text { 3- Tipos de sujidades/ superfície a ser limpa/ agente de limpeza } \\
\text { 4- Condições para uma limpeza adequada: temperatura da água, } \\
\text { concentração da solução, tempo de exposição, ação mecânica } \\
\text { 5- Fases da higienização: pré-enxagüe, solução detergente, enxágüe, } \\
\text { sanitização } \\
\text { 6- Apresentação das Instruções de Trabalho }\end{array}$ \\
\hline APPCC & $\begin{array}{l}\text { 1- Revisão de alguns conceitos: cadeia produtiva, alimentos inócuos, } \\
\text { tipos de contaminações } \\
\text { 2- Contaminações - Como EVITAR } \\
\text { 3- APPCC - definição, breve histórico } \\
\text { 4- Princípios do APPCC } \\
\text { 5- Estudo dos perigos no laticínio } \\
\text { 6- Fluxograma da produção de iogurte } \\
\text { 7- Identificação dos PCC e seus limites críticos no laticínio } \\
\text { 8- Formas de monitoramento } \\
\text { 9- Registros: importância do preenchimento correto } \\
\text { 10-Benefícios do APPCC }\end{array}$ \\
\hline
\end{tabular}

1 - Boas Práticas de Fabricação

2 - Procedimento Padrão de Higiene Operacional

3 - Análise de Perigos e Pontos Críticos de Controle 
Ao longo do trabalho, foram realizadas outras reuniões semelhantes, porém com grupos menores, de acordo com a necessidade ou à medida que novos funcionários eram admitidos.

Em todas as reuniões foi reforçada a importância do comprometimento de todos e a necessidade de uma postura responsável para a garantia da qualidade e segurança alimentar. A receptividade por parte dos funcionários durante os treinamentos foi bastante positiva, com freqüentes sugestões sobre aspectos da rotina da produção, as quais eram anotadas e analisadas posteriormente pelo gerente do laticínio, sendo algumas delas aproveitadas e colocadas em prática.

De uma forma geral, as mudanças comportamentais foram mais evidentes logo após as reuniões de treinamento, tornando-se menos perceptíveis com o passar do tempo, especialmente nos momentos em que o ritmo de produção era mais intenso e a jornada de trabalho prolongada. Almeida et al. (2002) apontam o caráter repetitivo das tarefas como um dos fatores responsáveis pela redução da qualidade higiênica na manipulação dos alimentos, propondo por isso, treinamentos mais constantes. McAloon (2003) sugere a criação de formas de estímulo às mudanças comportamentais, como por exemplo, premiações para os funcionários que apresentarem melhor desempenho em suas funções.

Ao longo do tempo pôde-se perceber maior resistência à mudança de hábitos e conduta de higiene por parte dos funcionários mais antigos, quando comparados com os recém admitidos. Assim, nem tudo que foi discutido e proposto nas reuniões foi por eles realizado de imediato. A esse respeito, Germano (2003a), comenta que os vícios adquiridos no transcorrer da vida profissional apresentam-se como um obstáculo importante à mudança de hábitos dos manipuladores, e McAloon (2003) acrescenta que o treinamento para os funcionários mais antigos deve ser diferenciado, contendo informações adicionais para que sejam obtidos melhores resultados.

Foram então organizados treinamentos freqüentes com grupos de três a quatro pessoas, de forma a não interferir no ritmo da produção e permitir a discussão dos pontos falhos específicos de cada um. Essa estratégia mostrou-se mais eficiente do que as reuniões com número maior de pessoas e os resultados mais satisfatórios quanto ao comprometimento obtido. 
Outra dificuldade encontrada foi com relação à rotatividade dos funcionários, com demissões e contratações constantes, impedindo a consolidação de uma equipe com a qualidade de trabalho desejada e tornando mais morosa qualquer melhoria que pudesse ocorrer. De acordo com Bauman (1990), a excessiva rotatividade pode levar a um treinamento inadequado dos funcionários dificultando o bom desempenho de suas funções. A partir do mês de Julho o grupo de funcionários se estabilizou, possibilitando melhores resultados com relação ao comportamento higiênico durante a produção.

Alguns funcionários apresentaram dificuldades no preenchimento dos registros de monitoramento dos PCCs, quer seja por esquecimento ou por não reconhecer sua importância. Apesar de alguns registros serem de conhecimento de todos, por fazerem parte da rotina do laticínio, pôde-se verificar que eram preenchidos de forma incorreta e com dados que nem sempre correspondiam à realidade.

Esse problema foi solucionado através de reuniões individuais com os responsáveis por essa tarefa e também propondo que fizessem sugestões para facilitar o preenchimento, como sugerido por Taylor (2003) que recomenda a participação dos operadores na elaboração dos registros como forma de aumentar o comprometimento e motivação. Hajdenwurcell (2002) cita a formalização das tarefas através da prática de registros como uma das grandes mudanças introduzidas pelo APPCC e que a dificuldade em registrar diariamente as informações pode ser superada com treinamentos mais intensivos dos funcionários.

A partir do mês de Julho, o treinamento em BPF para os novos funcionários passou também contar com uma visita às instalações do laticínio para que eles tivessem uma idéia geral de todas as fases da produção e vissem in loco muitos dos pontos abordados na palestra.

\subsection{Descrição do produto}

Eram fabricados no laticínio iogurtes com polpa de frutas nos tipos desnatado e parcialmente desnatado. Na Tabela 4 são apresentados os padrões para os dois tipos de iogurtes. 
Tabela 4 - Padrões de qualidade físico-química e microbiológica estabelecidos pelo laticínio para os iogurtes desnatado e parcialmente desnatado.

\begin{tabular}{|c|c|c|}
\hline Parâmetros & logurte desnatado & logurte parcialmente desnatado \\
\hline $\mathrm{pH}^{1}$ & $4,0-4,5$ & $4,0-4,5$ \\
\hline Acidez (ํD) ${ }^{1}$ & $50-80$ & $50-80$ \\
\hline Matéria gorda (\%) ${ }^{1}$ & $0-0,5$ & $1,5-1,7$ \\
\hline Coliformes totais (ufc/g) ${ }^{2}$ & 100 & 100 \\
\hline Coliformes fecais (ufc/g) ${ }^{2}$ & 10 & 10 \\
\hline Bolores e leveduras (ufc/g) ${ }^{2}$ & 200 & 200 \\
\hline
\end{tabular}

${ }^{1}$ Padrão estabelecido pela gerência do laticínio.

${ }^{2}$ Padrão idêntico à norma brasileira, definida em BRASIL (2000).

\section{Matérias primas}

Além do leite in natura, participavam da composição dos iogurtes os seguintes ingredientes:

- Leite em pó desnatado reconstituído;

- Concentrado protéico;

- Fermento lácteo: cultivo starter ou iniciador das bactérias Lactobacillus delbrueckii subsp. bulgaricus e Streptococcus thermophilus;

- Edulcorantes: açúcar cristal malha 30 (iogurte parcialmente desnatado) ou aspartame e acessulfame K (iogurte desnatado);

- Polpa de frutas sem pedaços sabores pêssego, frutas vermelhas e coco;

- Polpa de frutas com sementes sabor morango;

- Aromatizante idêntico ao natural de frutas (morango, pêssego, coco);

- Corante urucum;

- Espessante: carragena.

\section{Embalagens}

O iogurte era envasado em garrafas de polietileno de alta densidade (PEAD), fechadas com lacre de alumínio termoselável nas embalagens de $180 \mathrm{~g}$, e com tampa 
plástica PEAD e lacre de alumínio selado por indução, nas embalagens de $600 \mathrm{~g}, 900 \mathrm{~g} e$ $1000 \mathrm{~g}$.

Como embalagem secundária, as garrafas eram agrupadas com filme de polietileno de baixa densidade termoincolhível, em fardos contendo 6 ou 24 unidades ou em caixas de papelão com 24 unidades. As embalagens secundárias por sua vez eram empilhadas sobre estrados de madeira e revestidas com filme stretch (película de polietileno de baixa densidade).

\subsection{Fluxograma de processamento}

O fluxograma de processamento do iogurte foi elaborado através de observação visual e validado juntamente com gerente do laticínio, resultando no fluxograma final apresentado na Figura 3.

Paralelamente foram colhidas informações para elaborar a descrição, de forma seqüencial, das etapas do fluxograma e da forma de operação de cada equipamento. Tais descrições foram apresentadas na forma de "Instrução de Trabalho" e juntamente com os PPHOs foram afixadas em locais estratégicos na área de produção, permitindo a consulta pelos funcionários sempre que necessária. 


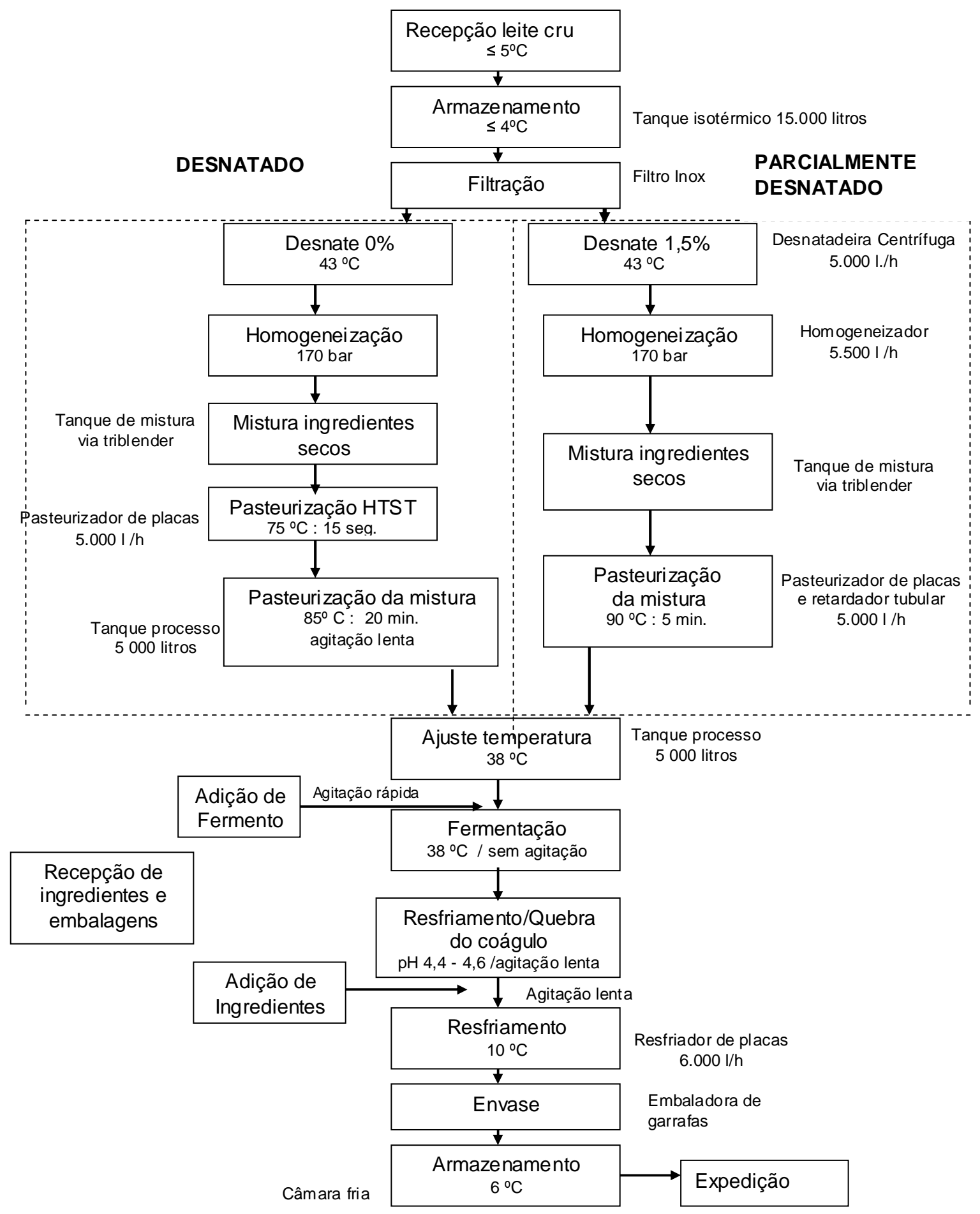

Figura 3 - Fluxograma de processamento dos iogurtes desnatado e parcialmente desnatado. 


\subsection{Aplicação dos princípios do APPCC}

\subsubsection{Levantamento dos Pontos para a Análise dos Perigos}

Nesta fase foi, realizado um estudo na literatura dos perigos de origem física, química e microbiológica que pudessem ocorrer no laticínio, considerando-se aspectos relativos à saúde pública e aos atributos de qualidade importantes para a indústria e para a satisfação do consumidor. Os resultados obtidos, de acordo com Forsythe (2002), Walstra et al. (2001), Tamine e Robinson (1991) e Oliveira, Fonseca e Germano (1999), forneceram base para posterior identificação dos perigos em cada fase distinta do processamento (Anexo D).

\subsubsection{Identificação dos PCCs e Medidas Preventivas}

Após o reconhecimento dos possíveis perigos e com o auxílio da árvore decisória proposta por Cezari e Nascimento (1995), foram analisadas todas as etapas do processamento e identificados os PCCs e suas respectivas medidas preventivas. Foram também considerados nesta avaliação os procedimentos de higienização dos equipamentos, por serem relevantes para o controle de contaminações. O resultado desse estudo é apresentado no Anexo $\mathrm{E}$.

Após a análise foram identificados 12 PCCs, sendo que as etapas de adição de ingredientes (PCC5), envase (PCC9) e higienização dos equipamentos (PCC12) estão relacionados às BPF e existe uma tendência de serem eliminados com o passar tempo, a medida que os treinamentos dos funcionários surtirem efeito.

A seguir são abordados de forma mais detalhada e de acordo com a revisão de literatura, cada ponto crítico encontrado e seus respectivos limites críticos. 
Recepção e armazenamento do leite cru - PCC1 e 2

$\mathrm{Na}$ etapa de recepção do leite foram utilizados três parâmetros para análise previa da matéria prima. A escolha levou em consideração a relevância das informações para avaliação da qualidade do leite, bem como a rapidez na execução dos testes e liberação dos resultados, de forma a não comprometer o ritmo de produção do laticínio. Assim, foram considerados: temperatura, acidez titulável e presença de antibióticos.

Sendo a temperatura um fator determinante no desenvolvimento microbiano e na conservação do leite, o limite crítico estabelecido para recebimento do leite cru foi de no máximo $5 \stackrel{\circ}{\circ}$ e para o leite armazenado o limite crítico foi de no máximo $4 \stackrel{\circ}{\circ}$.

Segundo Oliveira, Fonseca e Germano (1999), o teste de Dornic tem sido o mais utilizado para avaliação de acidez do leite, pois é capaz de detectar o aumento da concentração de ácido lático formado pela fermentação dos açucares durante o desenvolvimento microbiológico. O intervalo estabelecido como limite crítico para acidez do leite foi de 16 a $18 \stackrel{\circ}{D}$, valor normalmente encontrado no leite fresco, de acordo com Veisseyre (1988).

A presença de antibiótico no leite recebido foi considerada inaceitável, devendo apresentar resultado negativo, de acordo com a sensibilidade dos testes comerciais disponíveis no mercado.

\section{Recepção de ingredientes e embalagens - PCC3}

$\mathrm{Na}$ recepção dos ingredientes o limite crítico estabelecido foram as especificações definidas pelo laticínio e que devem constar no laudo que acompanha o produto. A análise visual do material e o laudo fornecido pelo fabricante foram os recursos utilizados no monitoramento.

Para os componentes das embalagens como tampas, rótulos e garrafas, o limite crítico estabelecido foi ausência de contaminações físicas (material estranho) e estarem de acordo com o padrão previamente estabelecido para cada uma delas quanto à cor, peso, dimensões e outros aspectos visuais definidos em conjunto com o fabricante.

\section{Pasteurização PCC4 e 6}

No processamento do iogurte especifico deste trabalho, a pasteurização ocorreu em dois momentos e as temperaturas utilizadas eram de $75^{\circ} \mathrm{C}$ por 15 segundos para 0 
leite cru e $85^{\circ} \mathrm{C}$ por 20 minutos para a pasteurização da mistura para o iogurte desnatado. No caso do iogurte parcialmente desnatado a pasteurização ocorria a $90{ }^{\circ} \mathrm{C}$ por 5 minutos. Como limites críticos foram estabelecidos os seguintes intervalos: 75 - 75,5 $\stackrel{\circ}{\circ}$ por 15 segundos, $85-85,5^{\circ} \mathrm{C}$ por 20 minutos e $90-90,5^{\circ} \mathrm{C}$ por 5 minutos.

\section{Fermentação e resfriamento - PCC7 e 8}

A temperatura utilizada pelo laticínio para a fermentação era de $38 \stackrel{\circ}{\circ}$ e o limite crítico estabelecido foi de 38 - $39 \stackrel{\circ}{\circ}$.

O padrão de $\mathrm{pH}$ do produto final definido pelo laticínio era de 4,0 a 4,5 e o resfriamento era realizado em duas etapas: no tanque fermentação (encamisado) quando eram adicionados ingredientes como polpas e aromas, e imediatamente antes do envase, através de resfriador de placas. Assim, para obter o produto final com pH no padrão desejado e considerando-se as características do processamento, o limite crítico do $\mathrm{pH}$ estabelecido para início do resfriamento foi de 4,4-4,6.

O monitoramento foi feito pela leitura da temperatura durante a fermentação e medição do pH para acompanhamento de sua queda e identificação do momento correto para interrupção do processo de fermentação.

Adição ingredientes e envase - PCC5 e 9

O limite crítico estabelecido para estas etapas foi a manipulação e comportamento dos manipuladores de forma higiênica, de acordo com as Boas Práticas de Fabricação e a adição de ingredientes nas quantidades estabelecidas pela formulação.

\section{Armazenamento do produto acabado e expedição - PCC10 e 11}

O limite crítico estabelecido para o armazenamento do produto acabado foi a temperatura no interior da câmara fria de 5-6 ํㅡ e para a expedição, as condições higiênicas no interior do baú e o perfeito funcionamento do equipamento de refrigeração dos mesmos durante o carregamento.

\section{Higienização dos equipamentos PCC12}

O sistema de limpeza existente no laticínio era do tipo CIP (clean in place) e dele faziam parte todos os equipamentos, tanques e linhas de circulação de produto. $O$ 
sistema contava com dois reservatórios, um para detergente alcalino e outro para detergente ácido, onde eram ajustadas as concentrações das soluções desinfetantes e também para onde elas retornavam após a circulação.

O método empregado para a higienização dos equipamentos na indústria depende de cada situação especifica, no entanto, de forma geral podem ser consideradas algumas etapas básicas, as quais foram estabelecidas como o limite crítico, como recomendada por Speer (1998):

- pré-enxague: temperatura da água 30-40 ํㅡ até que a água esteja visualmente limpa;

- limpeza com detergente alcalino: temperatura da solução de 80-85 ํㅡ, concentração de $1,25 \%$ e tempo de circulação entre 15 a 40 minutos dependendo do equipamento;

- enxágüe: com água limpa a 30-40 ํㅡ por 10 minutos ou até eliminação de todo o resíduo de detergente;

- limpeza com detergente ácido: temperatura da solução de 60-65 ํ, concentração de 1,0\% e tempo de circulação entre 15 a 30 minutos dependendo do equipamento;

- enxágüe: com água limpa a 30-40 ํㅡ por 10 minutos ou até eliminação de todo o resíduo de detergente;

- sanitização: temperatura da solução de 30-40 ำ, concentração de 0,2\%, circular no equipamento imediatamente antes do uso e não enxaguar em seguida.

Alguns equipamentos como desnatadeira e pequenas peças como conexões e registros, devem ser desmontados e submetidos à limpeza manual com o uso de escovas, seguindo as etapas básicas descritas. Evangelista (2001) recomenda a imersão das partes desmontadas em solução detergente por algum tempo antes do uso de escovas.

\subsubsection{Determinação das Formas de Controle dos PCCs}

São apresentadas nos Quadros 1, 2 e 3 as formas de controle, limites críticos e monitoramento de cada PCC. As respectivas ações corretivas, os registros e as formas de verificação encontram-se nos Quadros 4, 5, 6 e 7. No Anexo F estão presentes as instruções de trabalho para cada PCC e os registros de monitoramento. 


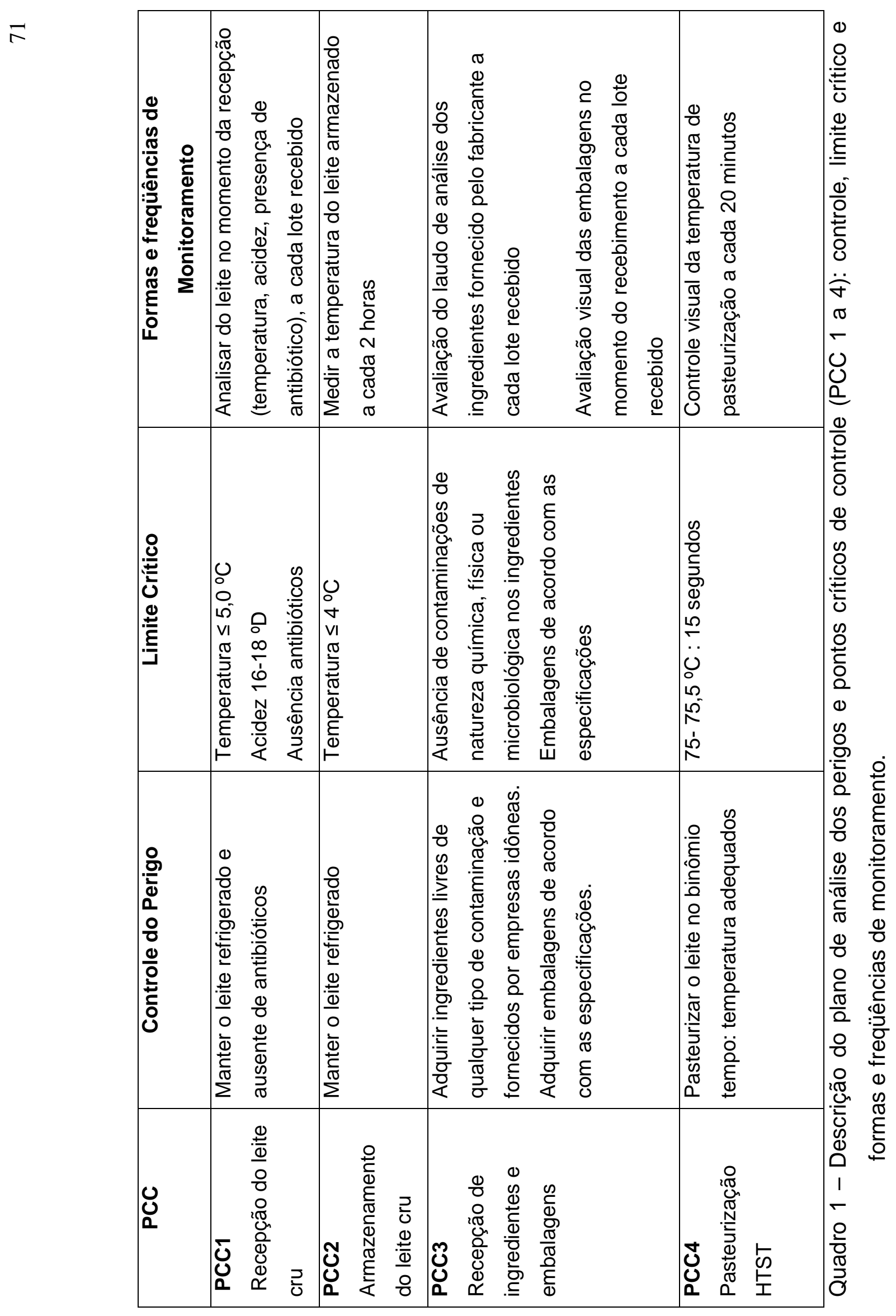




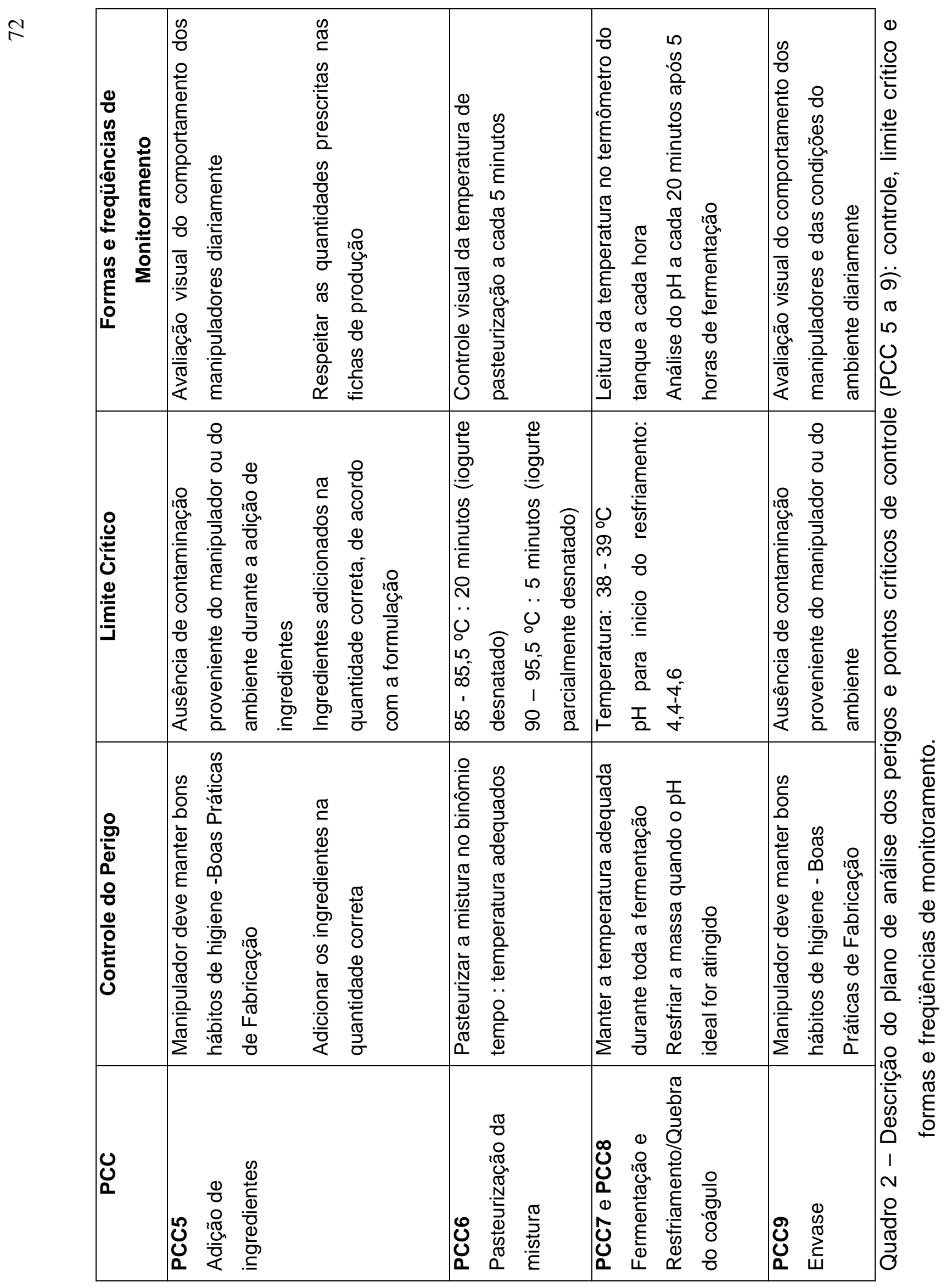




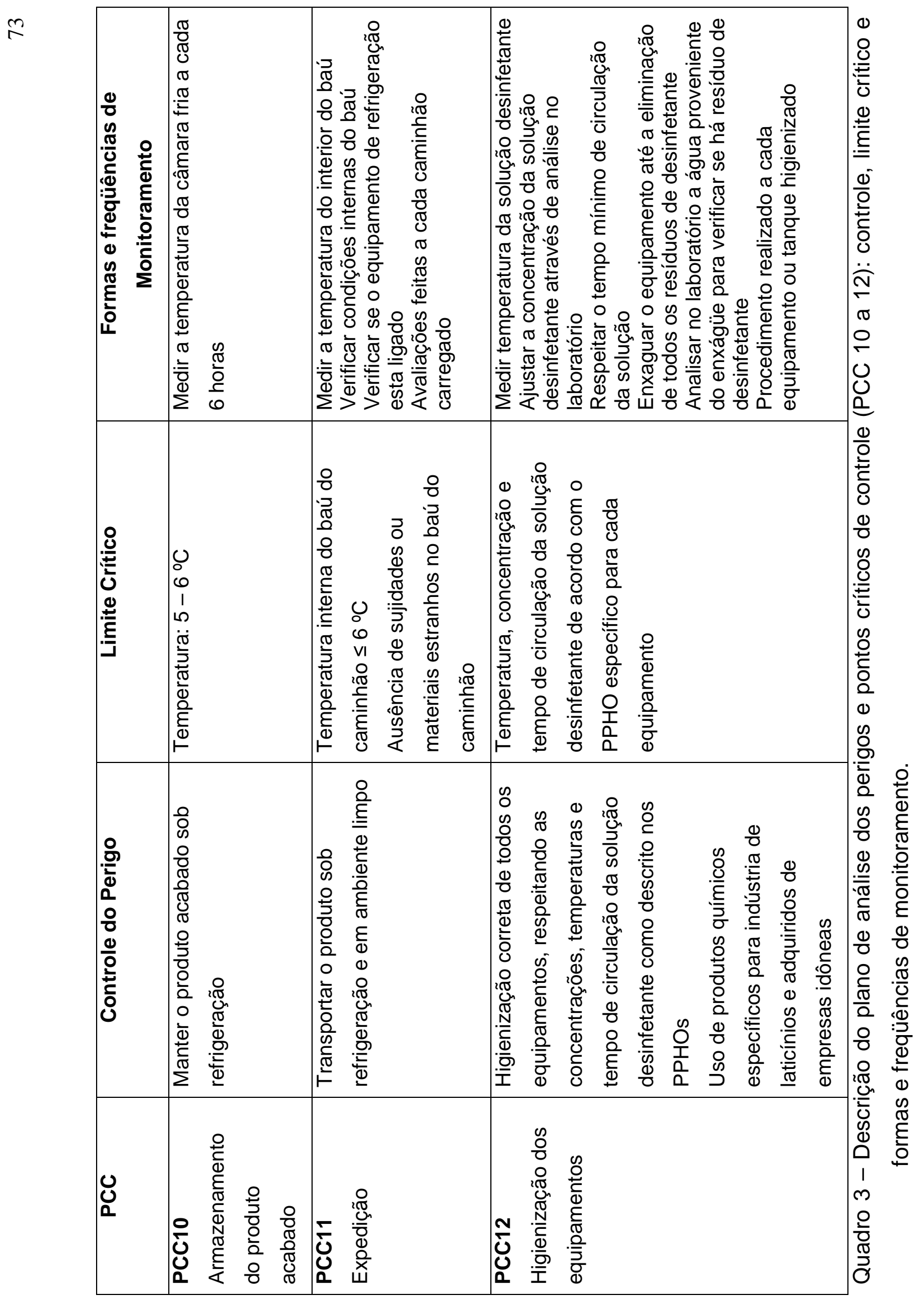




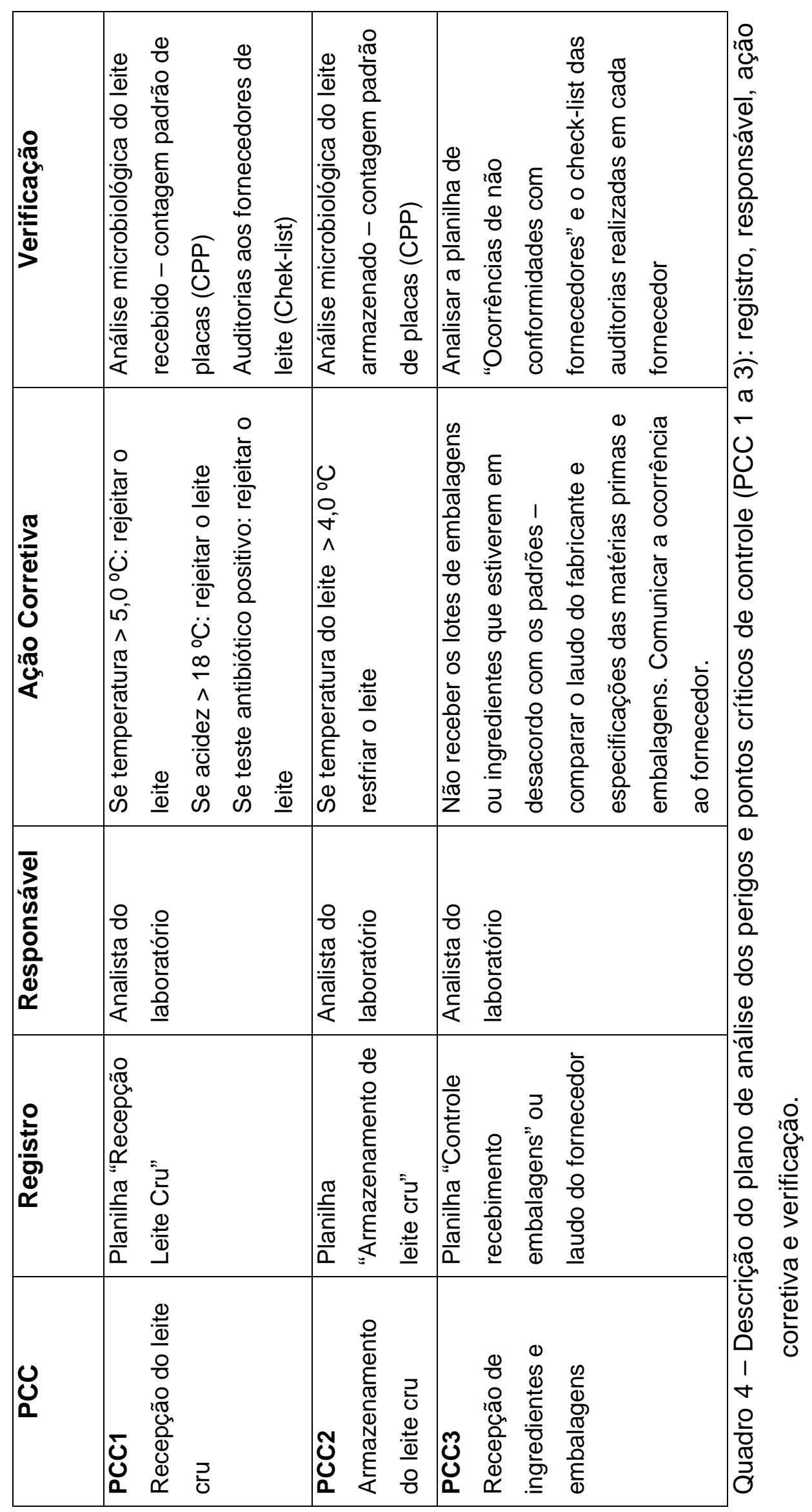




\begin{tabular}{|c|c|c|c|}
\hline 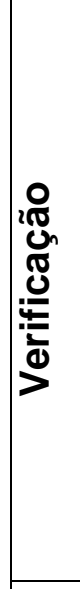 & 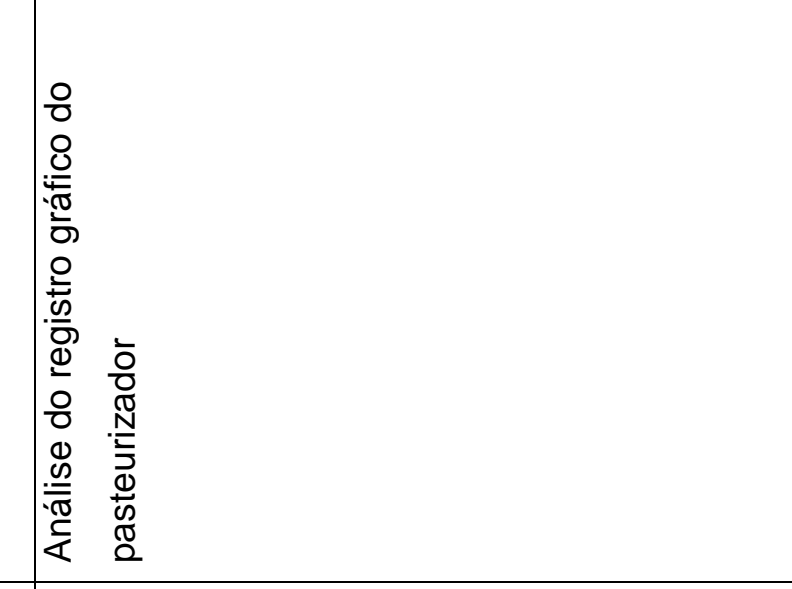 & 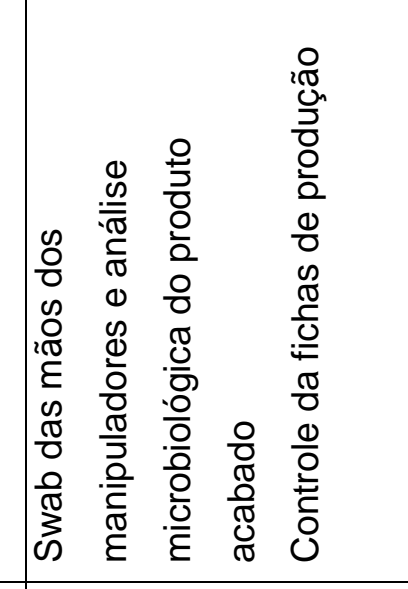 & 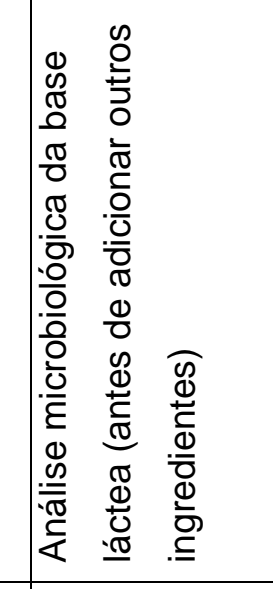 \\
\hline 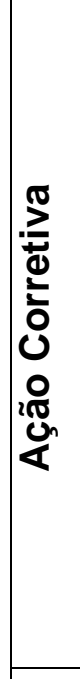 & 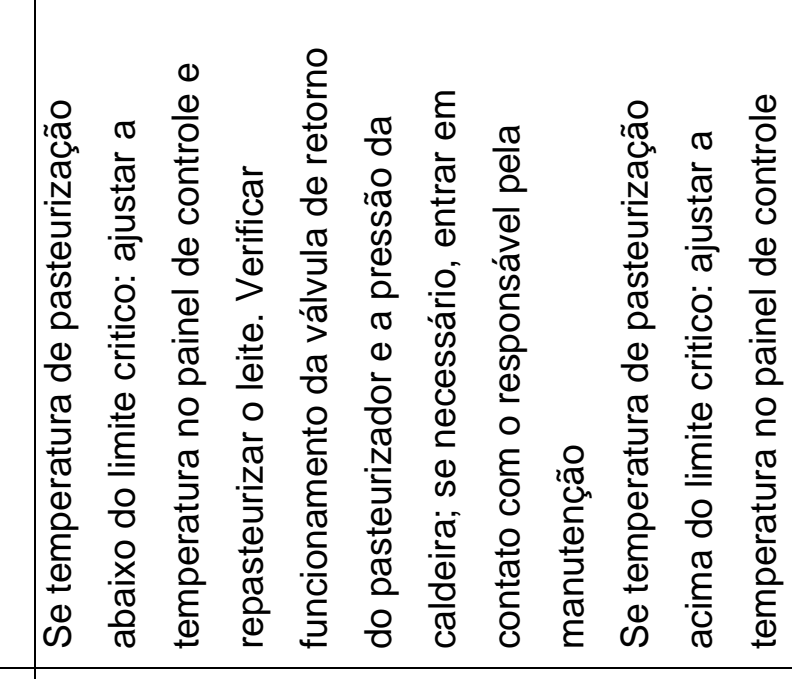 & 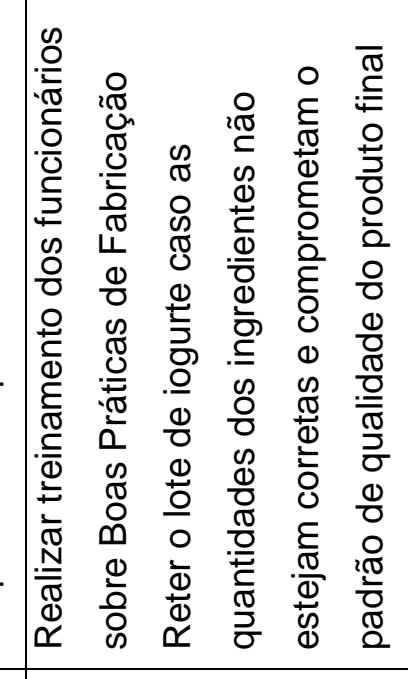 & 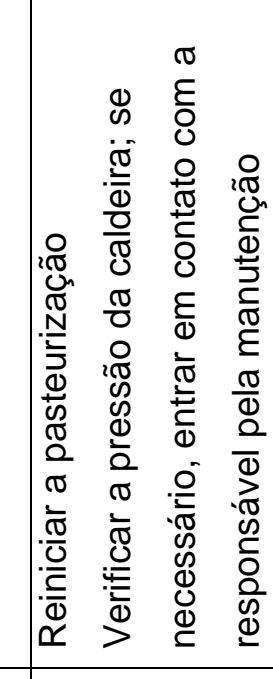 \\
\hline 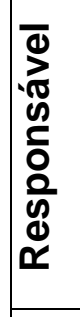 & 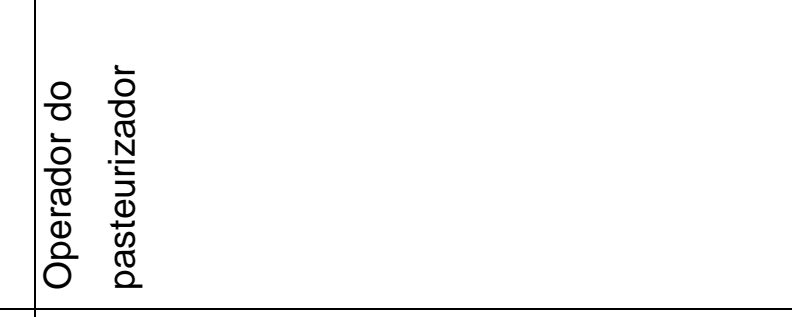 & 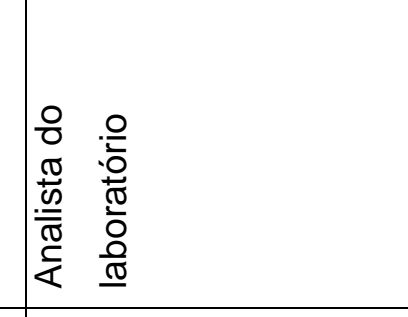 & 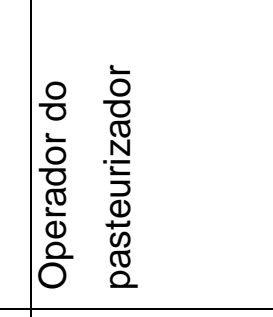 \\
\hline 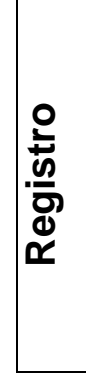 & 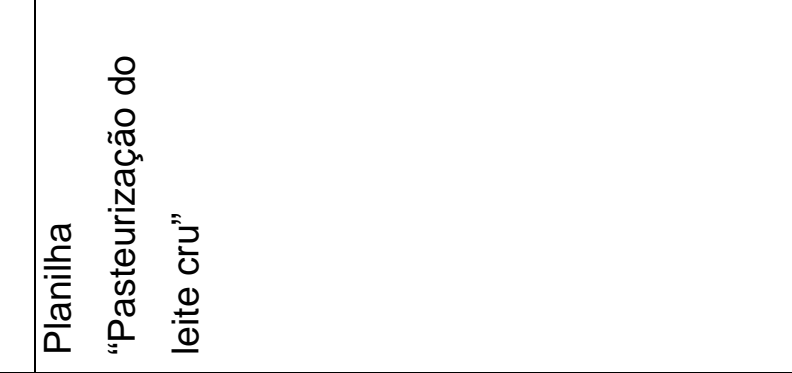 & 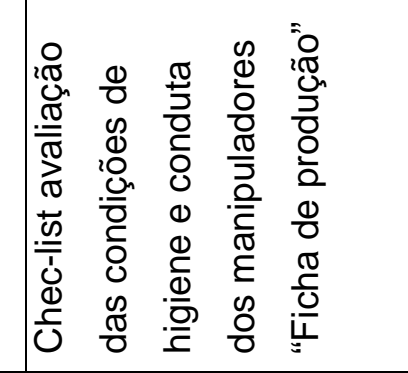 & 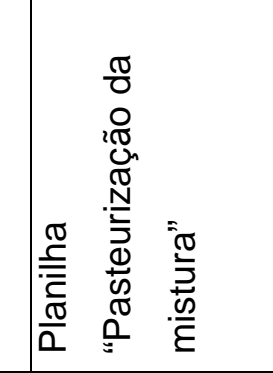 \\
\hline $\mathbb{Z}$ & 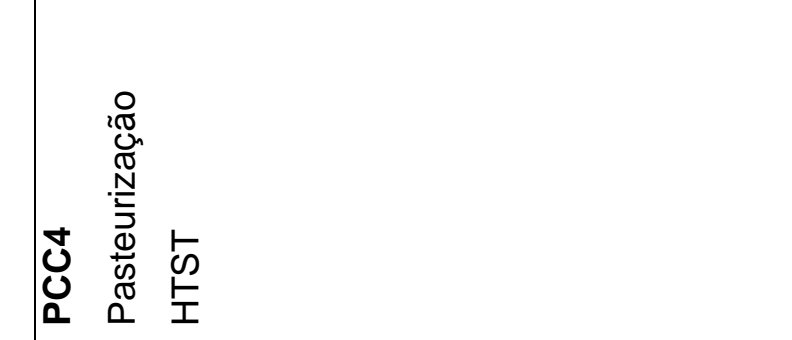 & 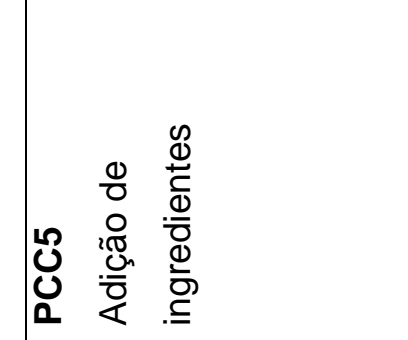 & 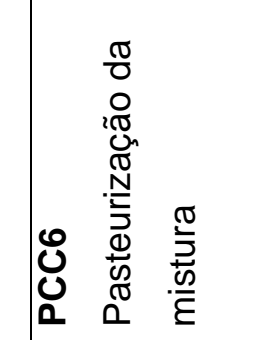 \\
\hline
\end{tabular}




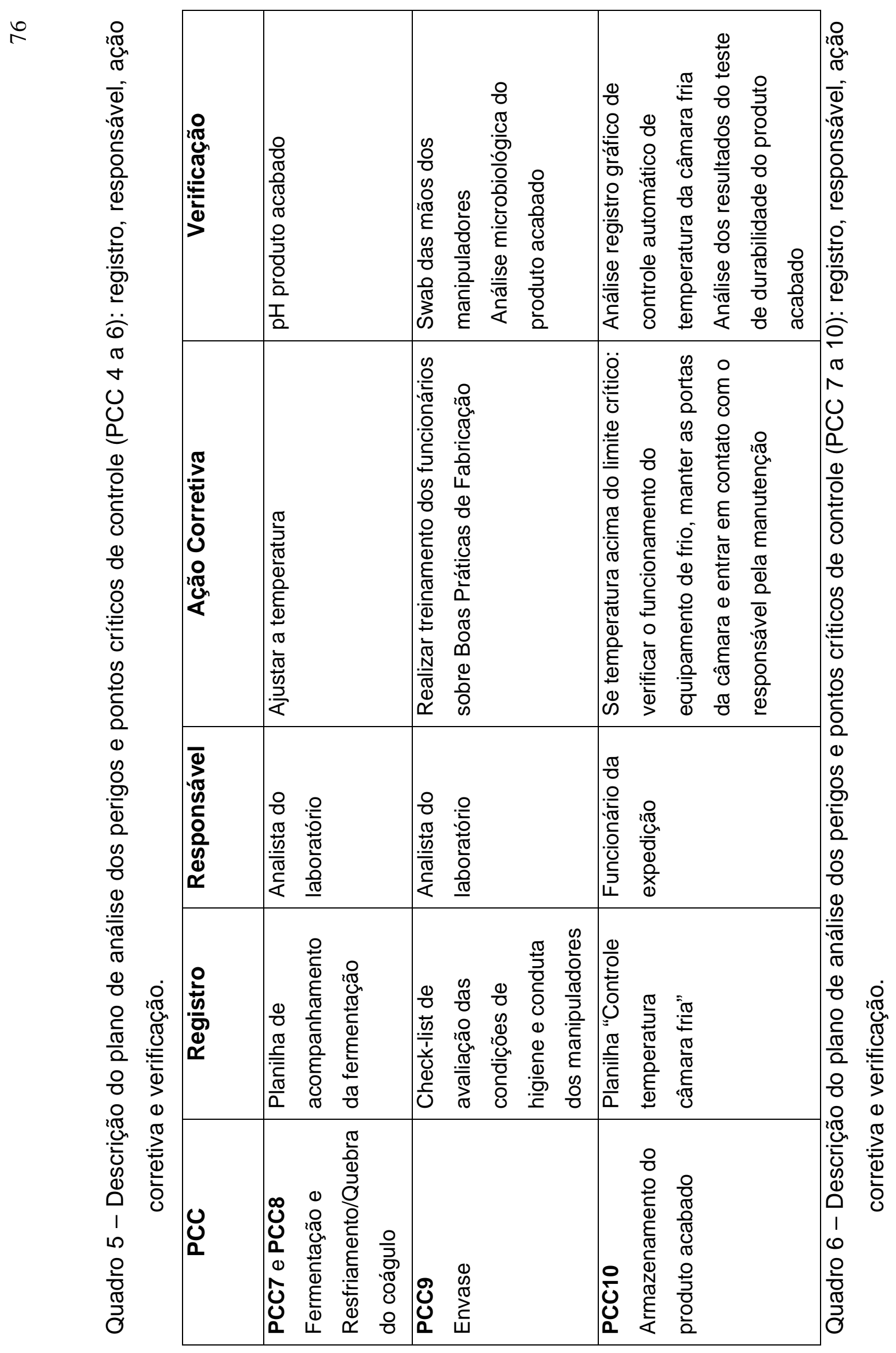




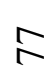

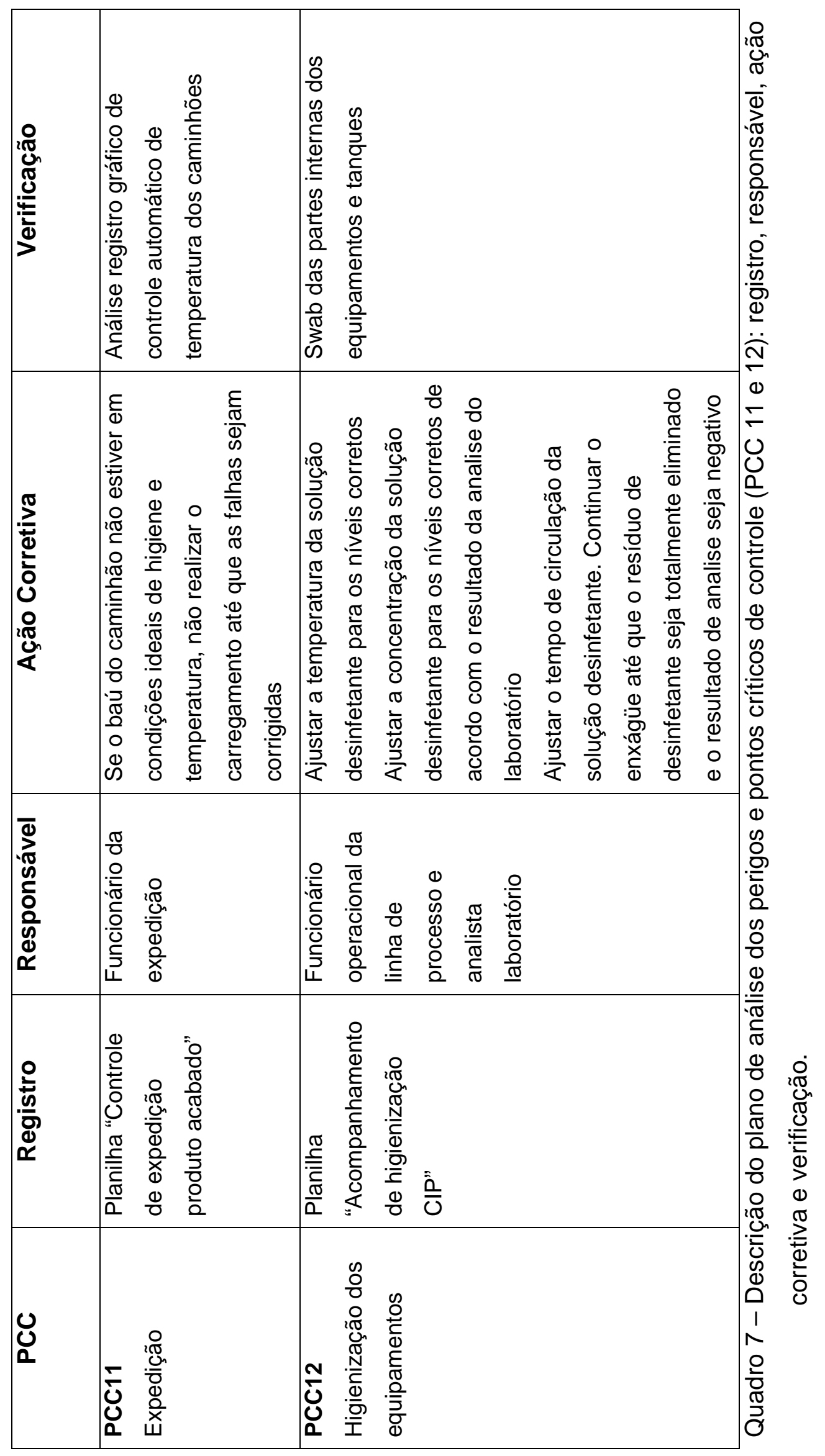




\subsubsection{O Processo de Monitoramento}

As avaliações dos monitoramentos dos PCCs compreenderam o período de Janeiro a Agosto de 2007 e os resultados são apresentados a seguir. A fase de implementação do sistema APPCC corresponde aos meses de Janeiro a Abril sendo que a partir de Maio até Agosto considerou-se o sistema implantado.

Recepção do leite cru - PCC1

No período de implantação do APPCC, nos meses de Janeiro a Maio, foram verificadas falhas no monitoramento deste PCC, com descarga e processamento do leite sem que fossem realizadas as análises laboratoriais necessárias, quer seja por ausência do funcionário responsável ou pela não coleta de amostra.

Era comum a descarga do leite para o tanque de armazenamento sem a prévia liberação pelo analista, mesmo quando este estava presente. Para correção do problema foi realizada uma reunião com os funcionários responsáveis e a partir de então o leite passou a ser descarregado somente após a conclusão das análises e liberação por parte do analista do laboratório.

Em Janeiro, foram identificadas falhas na refrigeração do leite em uma as fazendas fornecedoras, o que resultou em temperaturas elevadas no leite recebido, ultrapassando o limite crítico. O fornecedor foi comunicado da ocorrência e solicitado conserto do equipamento, mas mesmo assim a temperatura do leite proveniente dessa fazenda esteve acima do limite crítico até o final da coleta de dados.

Durante todo o período de monitoramento a temperatura ultrapassou 0 limite crítico diversas vezes (Figura 4). Aproximadamente metade dos lotes de leite recebidos ao longo do experimento encontravam-se acima de $5 \stackrel{\circ}{\circ}$ atingindo o máximo de $14 \stackrel{\circ}{\circ}$ no mês de Julho. O motivo desses desvios foi o fato do leite ter sido coletado imediatamente após a ordenha, sem tempo suficiente para resfriamento no tanque da fazenda. 


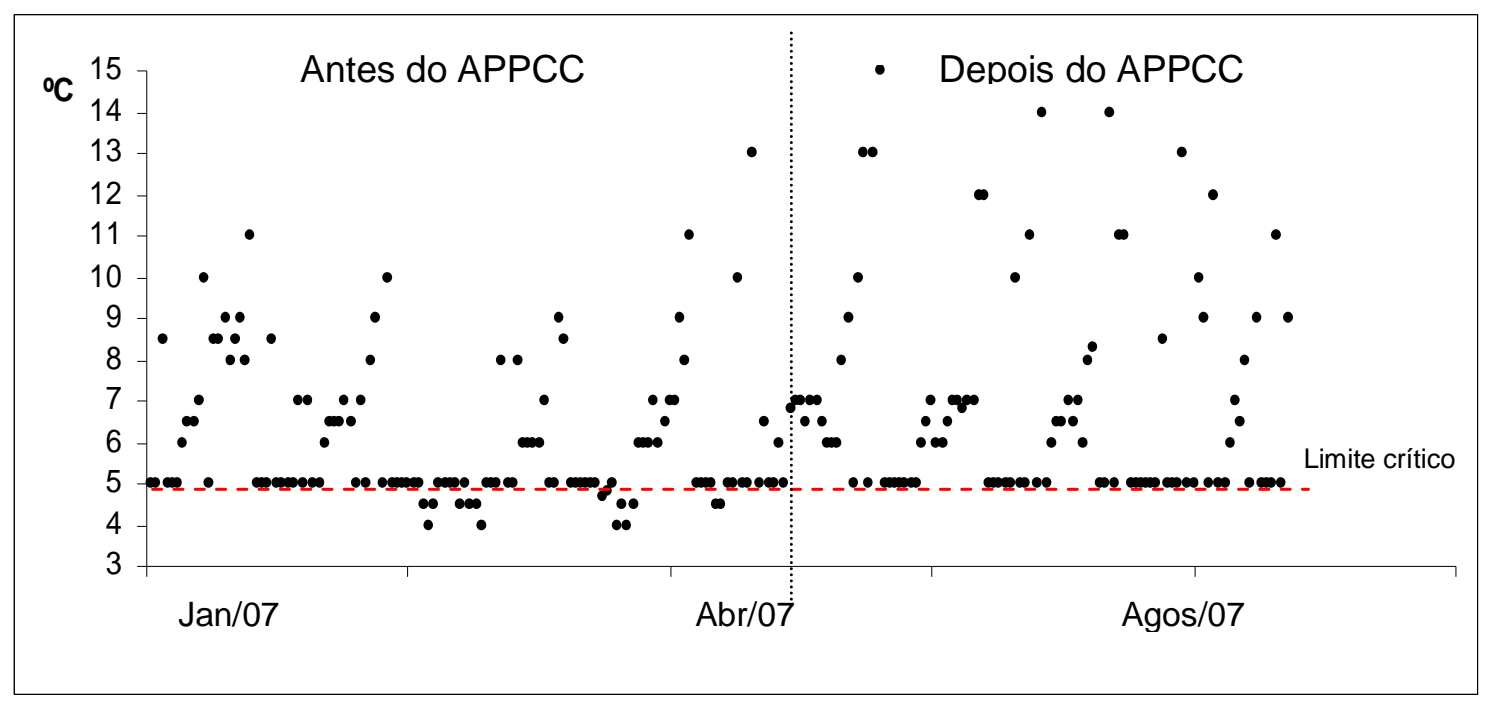

Figura 4 - Temperaturas dos lotes de leite recebidos pelo laticínio no período de Janeiro a Agosto de 2007, antes e após a implantação do APPCC.

Embora as temperaturas tenham variado, a acidez do leite se manteve dentro dos limites críticos aceitáveis durante todo o período do trabalho, estando $100 \%$ das amostras analisadas com acidez entre 15 e $16 \stackrel{\circ}{D}$.

Durante o período de monitoramento as análises identificaram presença de antibiótico em dois lotes recebidos, um no mês de Abril e outro em Maio e mesmo com esse resultado, o leite foi utilizado no processamento do iogurte. Os fornecedores foram comunicados e orientados quanto ao período de carência do antibiótico para as vacas em tratamento de mastite. A partir de Junho até Agosto, nenhuma amostra de leite apresentou resíduos de antibiótico, sendo este perigo considerado sob controle.

As auditorias realizadas nas fazendas fornecedoras de leite apontaram algumas falhas quanto à higienização dos equipamentos de ordenha e à concentração da solução detergente para higienização dos equipamentos, abaixo da recomendada pelo fabricante. Em todos os casos foram enviados relatórios às propriedades apontando os problemas encontrados e solicitando correções. 
Pelo fato da temperatura do leite recebido estar acima dos limites críticos até o final do período de monitoramento, o perigo microbiológico neste PCC foi considerado fora de controle.

\section{Armazenamento do leite cru - PCC 2}

Após análise dos perigos e medidas preventivas do APPCC, foi recomendada a instalação de um sistema que permitisse o resfriamento do leite cru antes do armazenamento. No entanto, até o final do trabalho, em Agosto de 2007, nenhuma mudança havia sido feita.

Assim, o limite crítico para este PCC foi ultrapassado durante todo o tempo e verificou-se que, nos horários mais quentes do dia, a temperatura do leite chegava a aumentar 2 a $3^{\circ} \mathrm{C}$ durante o período em que permanecia armazenado. $\mathrm{Na}$ Figura 5 são apresentadas temperaturas do leite armazenado durante 0 período de monitoramento.

A situação era agravada quando restava no tanque uma quantidade de leite do dia anterior e que seria misturado ao leite recebido no dia. Nessas condições, o leite mais novo tinha sua temperatura aumenta, chegando a ultrapassar o limite crítico.

Nos meses de Junho e Julho a temperatura chegou a $13^{\circ} \mathrm{C}$ em uma das medições e no mês de Agosto o uso do leite proveniente da mistura da coleta de dois dias, provocou alterações visíveis no iogurte, que foi, então, descartado. Após esse evento a análise do nível de acidez do leite armazenado também passou a fazer parte do monitoramento deste PCC, como forma de melhor controlar a qualidade diante das condições existentes.

A falta de um sistema de resfriamento para o leite cru fez com que este PCC estivesse permanentemente fora de controle. 


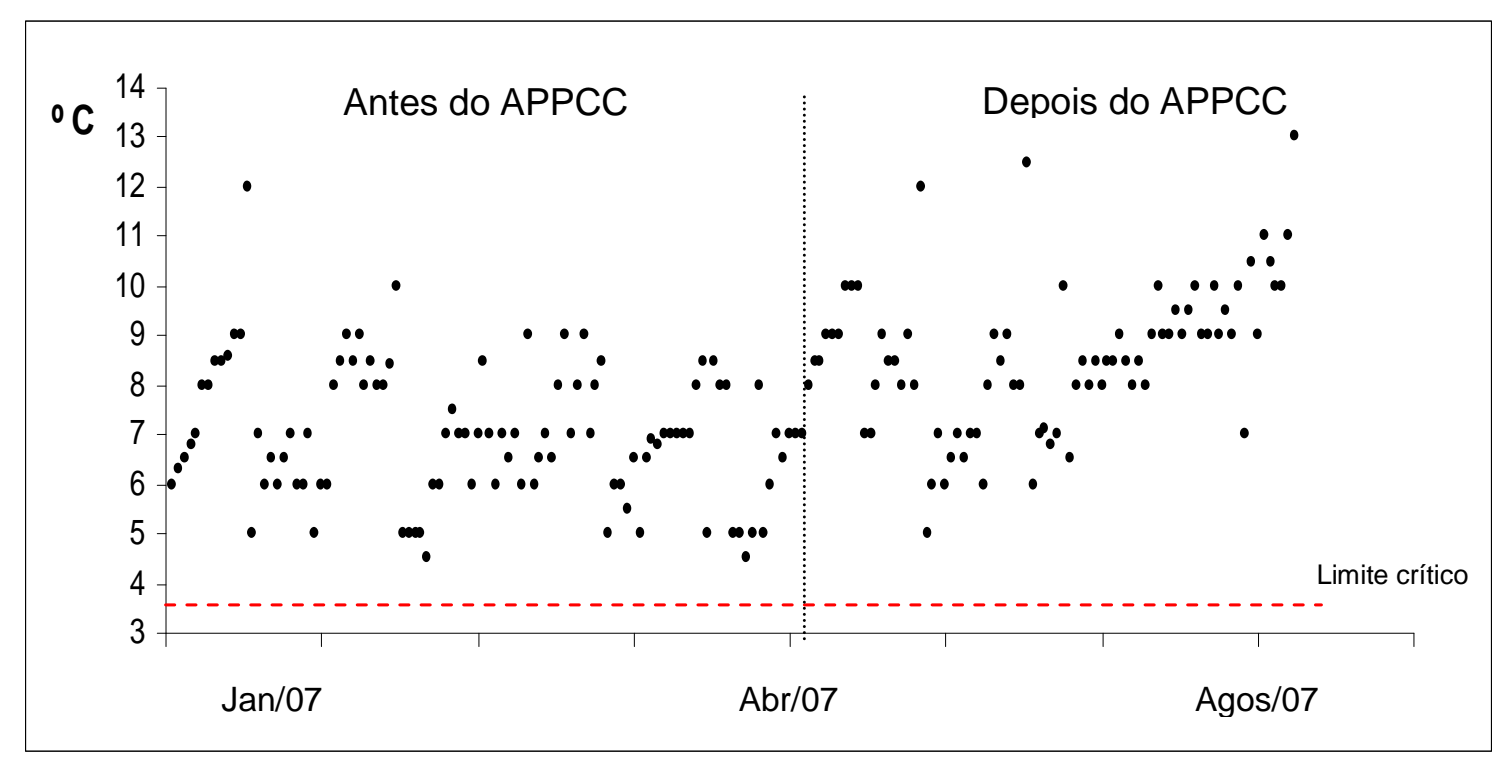

Figura 5 - Temperatura do leite armazenado no laticínio no período de Janeiro a Agosto de 2007, antes e após a implantação do APPCC.

Recepção de ingredientes e embalagens - PCC 3

Durante a execução do trabalho, nem sempre foi possível dispor de um funcionário para executar o monitoramento deste PCC de forma adequada. Era comum, a chegada das embalagens no período da noite, quando o responsável pelo monitoramento não estava presente, fazendo com que muitos problemas com relação às garrafas e tampas, fossem identificados somente durante o uso, já na linha de produção.

As garrafas e tampas eram recebidas acondicionadas em sacos plásticos formando fardos que eram armazenados dispostos em pilhas, até o momento do uso. Através do monitoramento foi verificado que muitos fardos de garrafas não possuíam nenhuma forma de identificação como número do lote e data de fabricação, impedindo qualquer controle ou rastreabilidade sobre as embalagens utilizadas.

Quanto às contaminações físicas, foram encontrados por diversas vezes, fios de cabelo, pêlos e mosquitos no interior dos fardos de garrafas e materiais estranhos fazendo parte da embalagem. Não conformidades quanto ao peso, 
presença de rebarbas e má distribuição do polietileno facilitando o amassamento das garrafas também foram constantes durante todo o período de monitoramento.

A auditoria realizada neste fornecedor apontou falhas de higiene por parte dos manipuladores e problemas estruturais na fábrica, além de falhas no controle de pragas e ausência de um controle de qualidade eficiente da produção. $O$ fornecedor foi comunicado dos problemas encontrados, mas as contaminações físicas e as não conformidades não deixaram de existir até o final do experimento.

Outro problema freqüente foi a ocorrência de não conformidades quanto às dimensões e peso das tampas recebidas, bem como tampas com lacres de alumínio defeituosos, fatos que levaram à interdição de alguns lotes e devolução ao fornecedor. Muitas dessas falhas foram identificadas somente na linha de produção, gerando atrasos no envase, perdas de tampas, falhas na selagem das garrafas e em algumas situações maior manipulação das garrafas já com produto e ainda sem tampa, aumentando o risco de contaminação. Esta situação permaneceu até o final do trabalho, de forma que, para as embalagens, o perigo foi considerado fora de controle.

Todos os ingredientes recebidos - polpas, edulcorantes, aromatizantes, leite em pó, concentrado protéico - estavam acompanhados do laudo de análise fornecido pelo fabricante e apresentaram-se dentro dos padrões estabelecidos durante todo o período do trabalho, não excedendo, portanto os limites críticos e mantendo-se sob controle.

Para garantir a segurança dos suprimentos é indispensável a cooperação dos fornecedores, com práticas seguras em suas produções e através de laudos que comprovem que as especificações dos suprimentos estão de acordo com os limites definidos pelo APPCC (WEBB; MARSDEN, 1995).

Pasteurização, fermentação, e resfriamento/quebra do coágulo-PCCs 4, 6, 7 e 8

O monitoramento da pasteurização identificou falhas por parte dos operadores nas situações em que a temperatura de pasteurização estava abaixo do limite crítico. Nesses casos o operador alterava o funcionamento do 
equipamento para a posição "manual", evitando assim a ação da válvula de retorno, não promovendo uma pasteurização efetiva.

No mês de Abril, verificou-se que por diversos dias não foi realizado o registro gráfico da temperatura de pasteurização, devido à falhas dos operadores na substituição dos gráficos. Foram feitas várias reuniões com os responsáveis pela pasteurização, os quais foram orientados para a correção dos problemas encontrados, e pôde-se considerar que a partir de então este PCC manteve-se sob controle.

A fermentação e o resfriamento mantiveram-se dentro dos limites críticos durante todo o período de execução do trabalho, não oferecendo riscos para a segurança do produto e para seus atributos de qualidade. $O$ monitoramento destes PCCs demonstrou que os perigos estavam sob controle.

Adição de ingredientes e envase - PCCs 5 e 9

O acompanhamento deste PCC através do check list para avaliação das condições de higiene e conduta do pessoal identificou falha comportamental de alguns manipuladores durante o processamento como, levar as mãos à boca, não lavar as mãos e as botas ao entrar na área de processamento, não lavar as mãos quando necessário durante a produção, falar em demasia durante o envase.

Durante o transcorrer do trabalho foram realizadas várias reuniões de treinamento específico para esses funcionários, reforçando alguns aspectos ligados às contaminações e aos hábitos corretos de higiene. Pôde ser percebida melhora no comportamento dos manipuladores, confirmada através dos resultados do swab das mãos. No entanto após algum tempo os funcionários voltavam a cometer os erros anteriores, indicando a necessidade de treinamentos constantes para que os perigos deste PCC sejam mantidos sob controle.

Armazenamento do produto acabado e expedição - PCCs 10 e 11

O monitoramento da temperatura da câmara fria identificou que o limite crítico foi ultrapassado por diversas vezes, principalmente durante o carregamento 
dos caminhões, momento em que as portas da câmara permaneciam abertas. Nessas situações a temperatura da câmara atingia 14 a $15 \stackrel{\circ}{ } \mathrm{C}$.

A rotatividade de funcionários responsáveis pela expedição até o mês de Maio dificultou o treinamento de forma adequada, e a leitura da temperatura da câmara deixou de ser feita por diversos dias.

Falhas no monitoramento e ausência de ações corretivas permitiram que a temperatura da câmara atingisse $24^{\circ} \mathrm{C}$ em um dia do mês de Julho levando a deterioração de diversos produtos armazenados. A partir desse mês o grupo de funcionários da expedição passou a ser fixo e o monitoramento realizado corretamente, bem como com as ações corretivas necessárias.

A avaliação efetuada nos baús dos caminhões antes do carregamento apontou diversos problemas. A solicitação para que os equipamentos de refrigeração dos caminhões permanecessem ligados durante o carregamento não foi respeitada e a temperatura dos baús mostrou-se acima do limite crítico durante todo o período de monitoramento. Não há registros dessas temperaturas, mas pôde-se perceber que estavam próximas à temperatura ambiente, especialmente nos dias quentes e com incidência de sol.

Diferente do recomendado, os equipamentos de refrigeração dos caminhões eram ligados somente após o término do carregamento, com as portas dos baús fechadas. Quanto às condições de higiene dos baús, apenas um deles apresentou odores estranhos e sujidades, ultrapassando o limite critico por cinco dias no mês de Abril.

Durante a elaboração do plano APPCC, foi sugerida a instalação de um abrigo para encosto dos caminhões na porta da câmara fria, que permitisse isolamento do ambiente externo, evitando a perda de frio ou entrada de ar quente, durante o carregamento.

Nenhuma mudança estrutural foi feita durante o período de coleta de dados, levando a expedição de produto acabado a permanecer acima do limite crítico durante todo o tempo e colocando em risco a integridade dos produtos. Assim, este PCC foi considerado fora de controle. 
Higienização dos equipamentos - PCC 12

O monitoramento da higienização dos equipamentos identificou que nos meses de Abril e Maio as concentrações das soluções detergentes não estavam sendo corretamente ajustadas e o tempo de circulação das mesmas também não estavam sendo respeitados.

Foram identificadas, através de observações visuais e swab de equipamentos, acúmulo de resíduos de iogurte nas máquinas de envase e em conexões e mangueiras dos tanques de processo, provenientes de falhas na higienização. Tais problemas levaram ao aumento freqüente da contagem de bolores e leveduras no produto acabado.

Foram verificadas também falhas no preenchimento das planilhas de monitoramento por diversos dias. Como medidas corretivas foram realizadas reuniões de treinamento com os responsáveis por essa etapa, mas mesmo assim foram encontradas, esporadicamente, falhas na higienização até o final do trabalho.

\subsection{Apuração dos custos do APPCC}

Os resultados da apuração dos custos totais do APPCC são apresentados na Tabela 5 e estão divididos nos itens investimento e custeio. Os investimentos compreendem a elaboração do plano, a adequação aos programas pré-requisitos e a implementação do sistema, e o custeio é relativo aos gastos mensais para sua manutenção. 
Tabela 5 - Custos totais associados à elaboração, implementação e manutenção do plano APPCC no laticínio.

\begin{tabular}{lr}
\hline 1. Investimento & \multicolumn{1}{l}{$\mathbf{R}$} \\
\hline 1.1. Elaboração do plano & $4.900,00$ \\
\hline Serviço de Consultoria (diagnostico) & $45.320,00$ \\
Serviço de Consultoria (elaboração do plano) & $6.583,20$ \\
\hline Serviço equipe APPCC (elaboração do plano) & $56.803,20$ \\
\hline Sub-total & \\
\hline & \\
\hline 1.2. Adequação aos programas pré-requisitos & $7.200,00$ \\
\hline Serviço de adequação BPF e PPHO & 990,00 \\
Tampa para caixa de captação de efluentes & 250,00 \\
Tela tipo alambrado para armazenamento dos produtos químicos & 400,00 \\
Armadilhas para moscas (reforma) & $1.400,00$ \\
Mezanino para almoxarifado de garrafas plásticas & $2.877,00$ \\
Contêineres para lixo na área externa & 300,00 \\
Insulfilme no almoxarifado dos rótulos & $1.000,00$ \\
Porta no almoxarifado de polpas e açúcar & 280,00 \\
Instalação de uma porta na sala de material de limpeza & 170,10 \\
Tapete sanitário & 120,00 \\
Plataforma nos tanques de limpeza CIP & $2.236,92$ \\
Extintores de incêndio & 435,30 \\
Placas indicativas de locais e de equipamentos & 40,00 \\
Plastificação de cartazes e avisos & 100,00 \\
Pranchetas de acrílico & 41,00 \\
Pastas plásticas para arquivo de documentos & 7,44 \\
Luvas para manipulação de produtos tóxicos & 11,10 \\
Avental para manipulação de produtos tóxicos & 59,30 \\
Oculos/máscara para manipulação de produtos tóxicos & 20,00 \\
Caixa plástica para setor de manipulação de produtos tóxicos & 989,74 \\
Japona e calça para uso na câmara fria & 21,60 \\
Luvas para uso na câmara fria & $4.000,00$ \\
Serviço de treinamento para programas pré-requisitos & $22.949,50$ \\
Sub-total & \\
\hline
\end{tabular}

\begin{tabular}{lr}
\hline 1.3. Implementação do plano & \\
\hline Serviço de treinamento para implementação do APPCC & $6.060,00$ \\
Resfriador de placas para leite cru - 10.000 I/h & $7.740,00$ \\
Abrigo para caminhão na doca de carregamento da câmara fria & $7.800,00$ \\
Instalação de ar comprimido para envase & $1.525,00$ \\
Instalação da linha de limpeza CIP para máquina envase & $3.240,00$ \\
Suporte para anotações na sala de processo & 200,00 \\
Sub-total & $26.565,00$ \\
\hline
\end{tabular}


Tabela 5 - Custos totais associados à elaboração, implementação e manutenção do plano APPCC no laticínio (continuação).

\begin{tabular}{lc}
\hline 2. Custeio mensal para manutenção do Plano de APPCC & $\mathrm{R} \$$ \\
\hline Material para laboratório & 739,17 \\
Material de escritório & 360,00 \\
Mão-de-obra para monitoramento dos PCC & 806,34 \\
Mão-de-obra para verificação dos PCC & 78,40 \\
Mão-de-obra para revisão do plano APPCC & 322,05 \\
Treinamento BPF e APPCC a cada 4 meses & 230,00 \\
Viagens & 75,00 \\
\hline Sub-total & $2.610,96$ \\
\hline & \\
\hline Sub-total de investimento & $106.317,70$ \\
\hline Sub-total de custeio mensal & $2.610,96$ \\
\hline
\end{tabular}

O total de investimentos estimados para implantação do APPCC foi de R\$ 106.317,70. De acordo com as etapas que compõem o projeto (Figura 6), 53\% (R\$ $56.803,20)$ são referentes à elaboração do plano propriamente dito, calculado através de uma estimativa de horas-trabalho para a realização deste serviço por uma empresa de consultoria da área, em conjunto com a equipe APPCC. Os gastos com a implementação do sistema representaram $25 \%$ do total investido $(R \$ 26.565,00)$, relacionados ao treinamento de pessoal e aquisição de equipamentos e materiais.

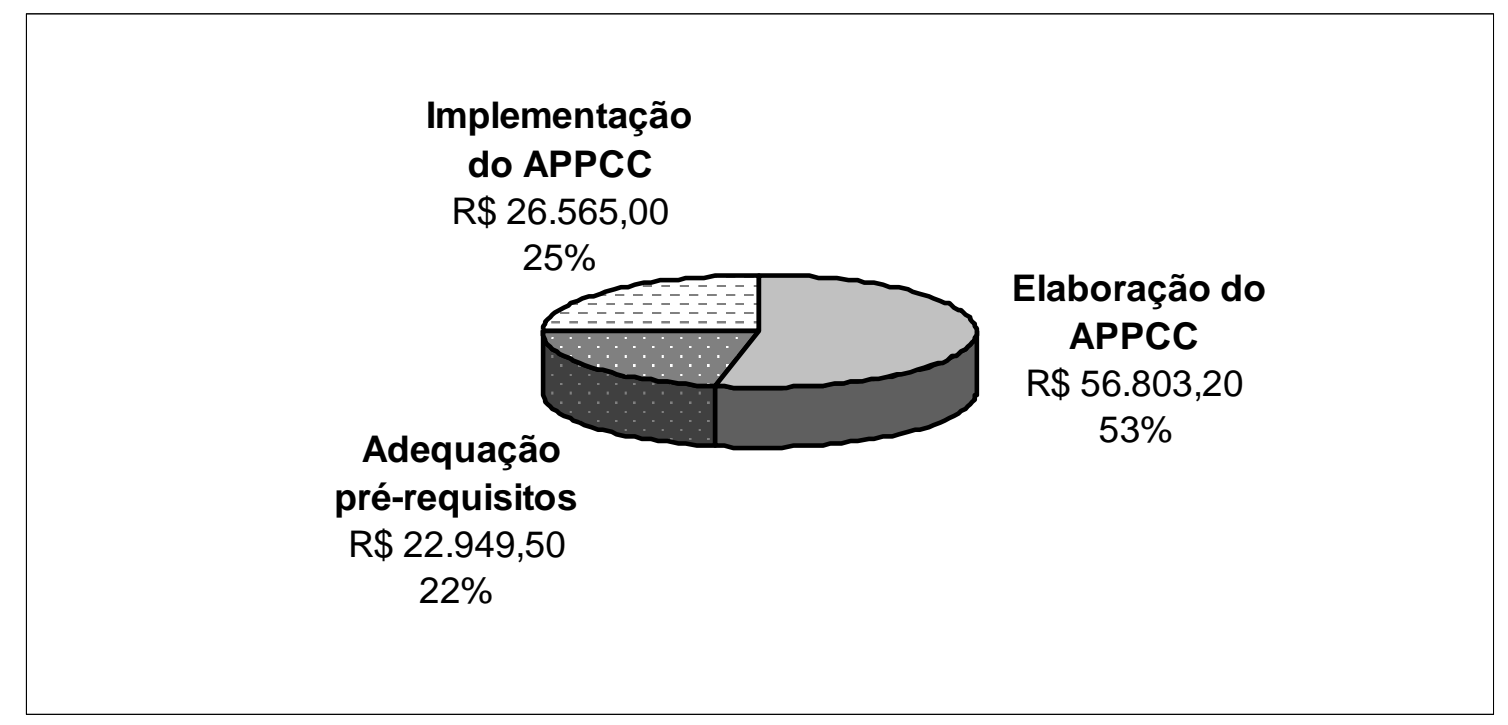

Figura 6 - Valores dos investimentos relativos ao APPCC em suas diferentes etapas. 
A adequação aos programas pré-requisitos representou $22 \%$ dos investimentos ( $R \$ 22.949,50)$, uma participação expressiva que incluiu mudanças estruturais, treinamento de pessoal e elaboração de documentação. A esse respeito, McAloon (2003) e Suwanrangsi (2000) relatam que uma redução significativa de tempo e custos iniciais do APPCC pode ser obtida quando as boas práticas de fabricação estão implantadas e bem conduzidas no dia a dia da empresa.

Em indústria de laticínios no Brasil, Roberto, Brandão e da Silva (2006), encontraram redução de $24 \%$ dos custos totais do APPCC com a adequação prévia aos programas pré-requisitos. Os resultados obtidos no presente estudo mostram que os custos seriam $22 \%$ menores caso esses programas estivessem devidamente implantados.

A Figura 7 apresenta de forma detalhada a composição dos investimentos e pode-se observar que $48 \%$ destes $(\mathrm{R} \$ 50.220,00)$ foram relativos exclusivamente à consultoria externa, fornecida por uma empresa terceirizada. Este item foi composto pela estimativa de custo de uma visita para diagnóstico inicial e mais 176 horas de trabalho destinadas à orientação da equipe APPCC, incluindo os gastos com viagens.

Bata et al. (2006), em experimento realizado em indústria de refeições, reportam $11 \%$ dos investimentos do APPCC para serviços de consultoria no desenvolvimento do plano, e Maldonado et al. (2005) relatam que este item superou as expectativas dos profissionais do setor de carnes no México, sendo o segundo maior custo na implementação do APPCC. No presente trabalho, esses valores representam uma parcela significativa dos custos, fato que, de acordo com Taylor (2003) e Bata et al. (2006) é comum em empresas de médio porte que possuem recursos limitados de pessoal, sem disponibilidade de tempo e sem a experiência necessária para elaborar e implantar o sistema. 


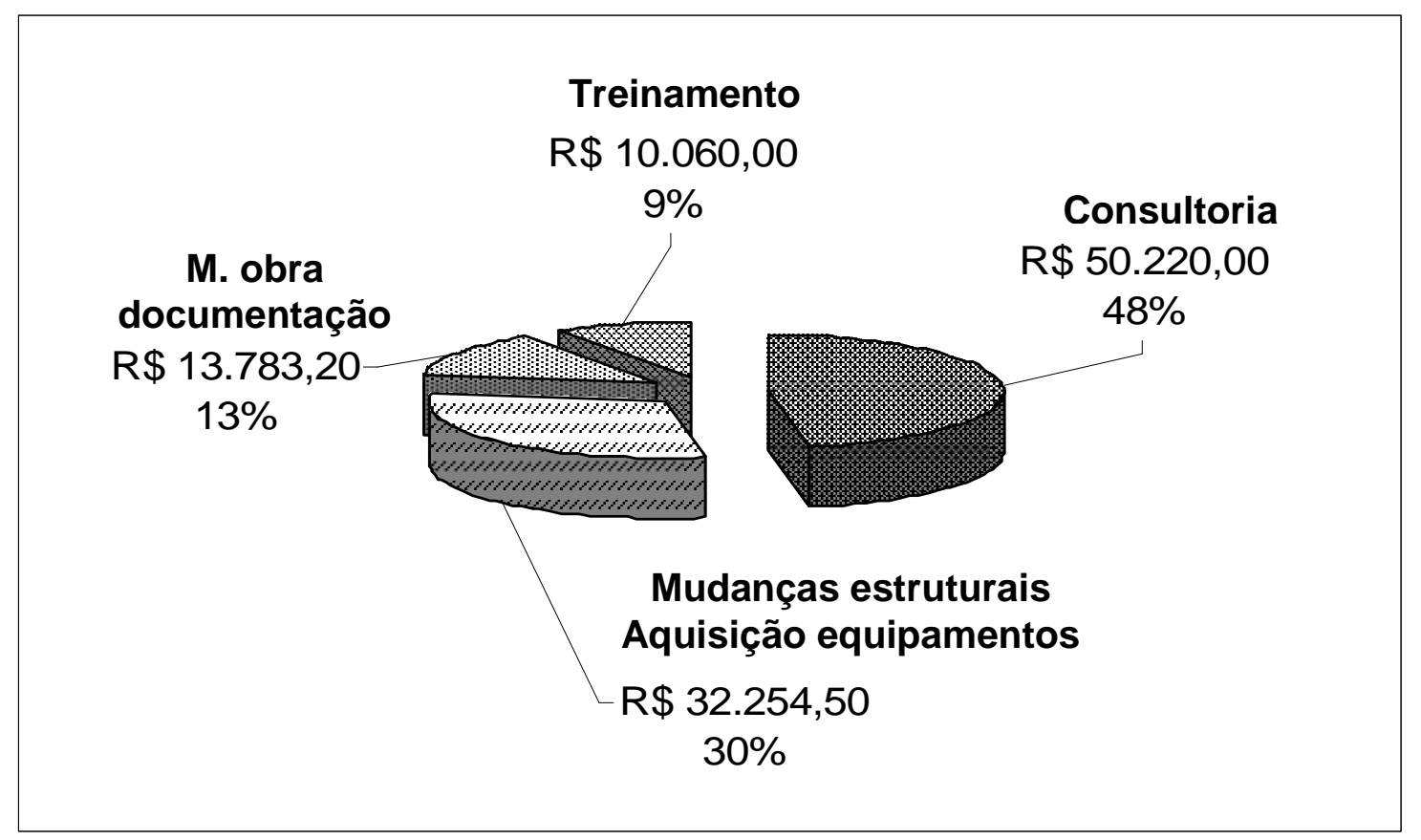

Figura 7 - Valores dos diversos tipos de investimentos relativos ao APPCC.

O segundo maior custo foi para realização de mudanças estruturais na planta e para aquisição de equipamentos, totalizando $30 \%$ dos investimentos $(R \$$ 32.254,50). Destes, $\mathrm{R} \$ 20.505 .00$ foram exclusivos para o APPCC, relativos na sua maior parte, à aquisição de um resfriador para o armazenamento do leite cru (PCC1) e de um abrigo na doca de carregamento da câmara fria (PCC11). A aquisição desses itens não foi realizada até o final do trabalho, sendo então considerados os valores de mercado.

Resultado similar foi encontrado por Maldonado et al. (2005), onde a aquisição de equipamentos foi apontada como o item mais elevado do total dos custos. Resultado oposto, no entanto, foi obtido por Henson, Holt e Northen (1999) com indústrias de laticínios do Reino Unido, onde esse item, juntamente com consultoria externa, foram os menos importantes.

Os custos totais com documentação foram de $\mathrm{R} \$ 13.783,20$ ou $13 \%$ do total investido, com aproximadamente $56 \%$ desse valor $(\mathrm{R} \$ 7.200,00)$ relativos aos programas pré-requisitos, decorrentes do tempo demandado para descrição dos procedimentos de BPF e PPHO. 
Os gastos com treinamentos corresponderam a $9 \%$ dos investimentos ( $\mathrm{R} \$$ 10.660,00), sendo $R \$ 6.060,00$ destinados do sistema APPCC. Este item é reportado na literatura como tendo impacto elevado nos custos do sistema, e onde são também encontradas as maiores dificuldades, em decorrência da necessidade de treinamentos constantes e obtenção de motivação dos funcionários, especialmente supervisores e gerentes (HENSON; HOLT; NORTHEN, 1999; MALDONADO, et al., 2005). No caso deste trabalho, não houve necessidade de paralisação da produção para os treinamentos, não sendo consideradas, portanto, perdas de produção, como normalmente ocorrem em outros estudos.

É importante ressaltar que se torna difícil a comparação entre os dados disponíveis na literatura sobre os custos do APPCC, em virtude das diferenças quanto às condições individuais e ao setor de atuação de cada planta, bem como à metodologia utilizada para apuração e análise dos custos.

Quanto ao custo mensal para manutenção do sistema, foi de $R \$ 2.610,96$ e compreenderam gastos com materiais de laboratório e de escritório, mão de obra para monitoramento dos PCCs, para verificação e revisão do plano, e treinamento de pessoal.

De acordo com a Figura 8, os maiores gastos para a manutenção do sistema foram relativos ao tempo para o monitoramento dos PCCs, correspondendo a $31 \%$ do total do custeio $(R \$ 806,34)$, incluindo registros e ações corretivas.

Dados de pesquisas realizadas em indústrias de diversos setores apontam, o tempo gasto com registros do APPCC como o maior custo para sua manutenção, geralmente superando as expectativas dos profissionais (BATA et al., 2006; HENSON; HOLT; NORTHEN, 1999; BUCHEWEITZ, 2001). 


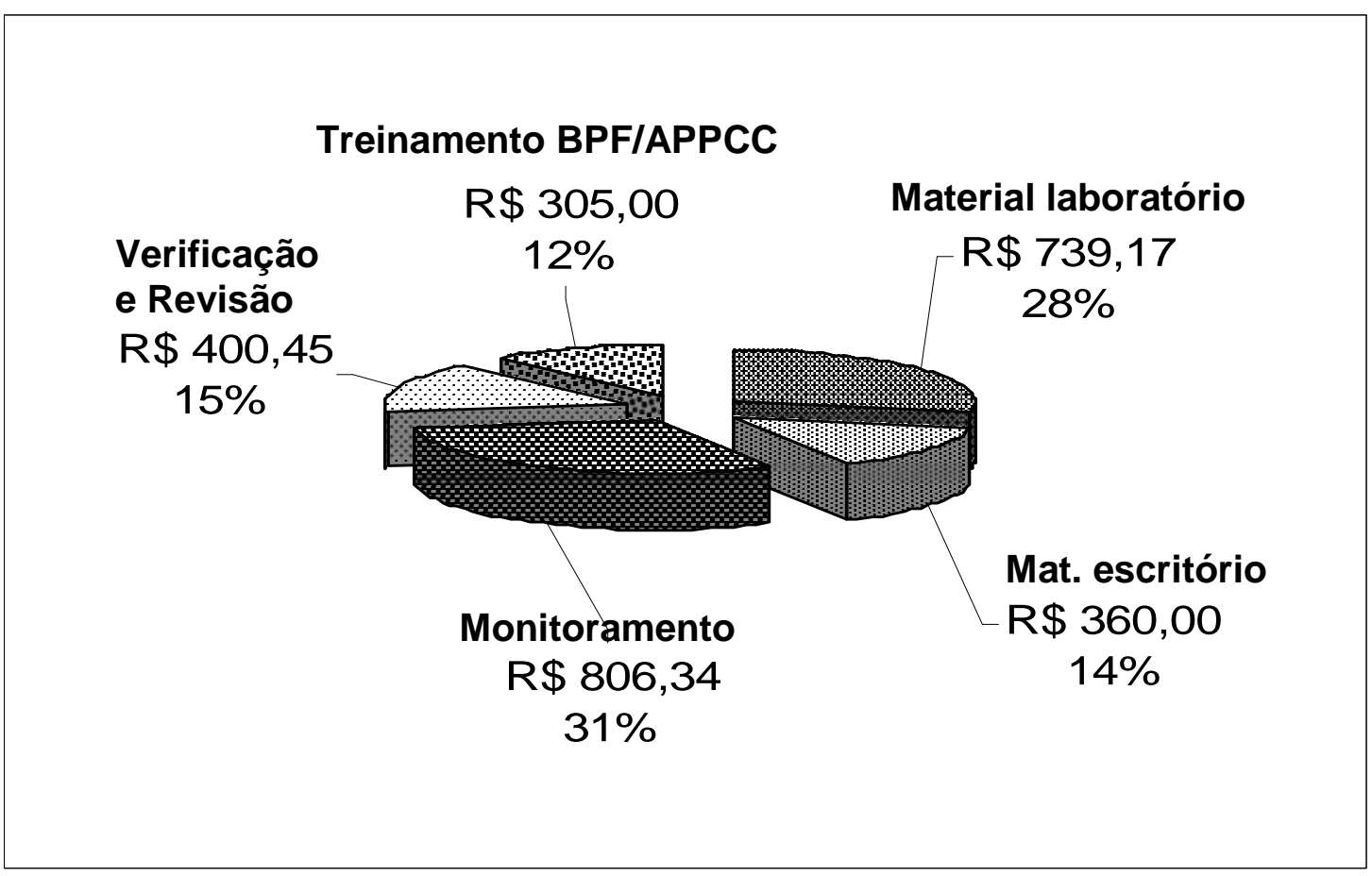

Figura 8 - Custo mensal de manutenção do APPCC.

Considerando-se os gastos totais com mão de obra temos $46 \%$ dos custos ou $R \$ 1.206,79$ relativos ao monitoramento, verificação e revisão do APPCC. O detalhamento desses custos é apresentado na Tabela 6.

Tabela 6 - Custo da mão de obra para manutenção do APPCC ${ }^{\star}$.

\begin{tabular}{lccc}
\hline & $\mathrm{h} / \mathrm{mês}^{1}$ & custo /hora (R\$) & total (R\$) \\
\hline 1. Monitoramento dos PCC: & & & \\
$\quad$ Analista de laboratório & 125,79 & 4,90 & 616,37 \\
Operador de pasteurização & 2,6 & 9,59 & 24,93 \\
$\quad$ Funcionário responsável pela expedição & 3,5 & 8,49 & 29,43 \\
$\quad$ Gerente & 8 & 16,95 & 135,60 \\
$\quad$ Sub total & & & 806,33 \\
2. Verificação dos PCC: & 16 & 4,90 & \\
$\quad$ Analista de laboratório & & & 78,40 \\
3. Revisão do APPCC: & 19 & 16,95 & \\
$\quad$ Gerente & & & $\mathbf{1 . 2 0 6 , 7 9}$ \\
\hline Total & & & \\
\hline${ }^{*}$ Análise de perigos e pontos críticos de controle & &
\end{tabular}


Verifica-se que a maior parte desses custos são relativos à atividade de monitoramento. A redução do número de PCCs que poderia ocorrer na medida em que as das boas práticas de fabricação fossem sendo consolidadas traria uma redução desses valores ao longo do tempo.

Os gastos com material para laboratório corresponderam a $28 \%$ do custeio mensal ( $R \$ 739,17)$, devendo-se ao fato de grande parte dos monitoramentos e verificações serem realizadas através de análises laboratoriais. Mandonado et al. (2005) reportam os gastos com análises como os mais significativos na operacionalização do plano, superando inclusive as expectativas.

Quanto ao treinamento periódico dispensado aos funcionários, foi aqui considerada uma reciclagem a cada quatro meses, ministrada por um profissional contratado, e representou $12 \%$ dos custos $(R \$ 305,00)$. Através do monitoramento dos PCCs verificou-se que os treinamentos são imprescindíveis para o perfeito funcionamento do APPCC e de acordo com Bucheweitz (2001), em pesquisa com empresas de serviços de alimentação, a atividade foi o segundo maior custo de manutenção do sistema.

Considerando-se a produção média mensal do laticínio de $398.800 \mathrm{~kg}$ de iogurte, verificou-se que o custo para a manutenção do sistema representou um impacto de $R \$ 0,01 / \mathrm{kg}$ de iogurte embalado, equivalente a $0,5 \%$ do custo de produção. Os gastos com investimento, caso fossem diluídos para a produção de um único ano, significariam um adicional de $R \$ 0,02 / \mathrm{Kg}$, totalizando $R \$ 0,03 / \mathrm{Kg}$ ou $1,5 \%$ do custo do quilo do iogurte embalado.

Os resultados do presente trabalho são coerentes com os obtidos por Bucheweitz (2001), onde as despesas com a manutenção do APPCC apresentaram participação entre 0,01 e 2,91\% nos custos de produção, com valor médio de $1,42 \%$. De acordo com o autor os custos totais do APPCC tendem a ser menores com o aumento do porte da empresa. 


\subsection{Avaliação dos benefícios do APPCC}

\subsubsection{Qualidade microbiológica do produto acabado}

A Tabela 7 apresenta o resultado das médias das análises microbiológicas do produto acabado, antes e depois da implantação do APPCC.

Tabela 7 - Contagem de bolores e leveduras, coliformes totais e coliformes fecais ${ }^{1}$ antes e depois da implantação do APPCC.

\begin{tabular}{lccc}
\hline & $\begin{array}{c}\text { Bolores e Leveduras } \\
(\log \text { ufc/g })\end{array}$ & $\begin{array}{c}\text { Coliformes Totais } \\
(\log \text { ufc/g })\end{array}$ & $\begin{array}{c}\text { Coliformes fecais } \\
(\log \text { ufc/g })\end{array}$ \\
\hline Antes APPCC & $2,22 \pm 1,12^{\mathrm{a}}$ & $1,55 \pm 1,17^{\mathrm{a}}$ & $0,13 \pm 0,43^{\mathrm{a}}$ \\
Depois APPCC & $1,89 \pm 1,18^{\mathrm{b}}$ & $1,43 \pm 1,26^{\mathrm{a}}$ & $0,13 \pm 0,45^{\mathrm{a}}$ \\
\hline
\end{tabular}

${ }^{1}$ Resultados expressam a média \pm desvio padrão de 319 análises do produto acabado realizadas antes e depois da implantação do APPCC.

* Em uma mesma coluna, médias seguidas de letras desiguais diferem estatisticamente $(P<0,05)$.

A Figura 9 apresenta a dispersão das contagens de bolores e leveduras no produto acabado ao longo do período experimental. Foi encontrada diferença estatística entre as médias das contagens antes e após a implantação do APPCC $(P<0,05)$, com tendência de queda à medida que o sistema foi sendo implantado. Os valores médios tenderam a permanecer abaixo do limite máximo estabelecido pela legislação, que é de 2,3 log ufc/g (BRASIL, 2000). 


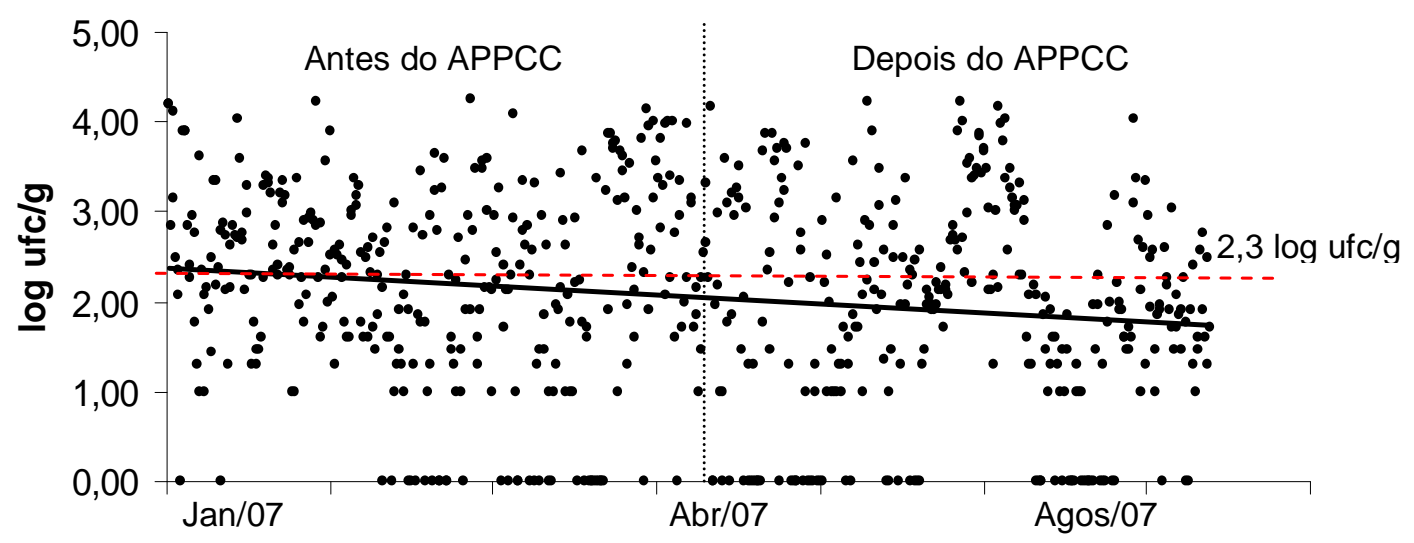

Figura 9 - Dispersão das contagens de bolores e leveduras (log ufc/g) nas amostras de iogurte analisadas antes e depois da implantação do APPCC.

Na Figura 10 é apresentada a distribuição dos valores para coliformes totais nas amostras analisadas ao longo do período. Não foram encontradas diferenças significativas entre as médias das contagens antes e depois do APPCC implantado $(P=0,215)$, com tendência de manterem-se abaixo do limite máximo de 2,0 log ufc/g previsto pela legislação.

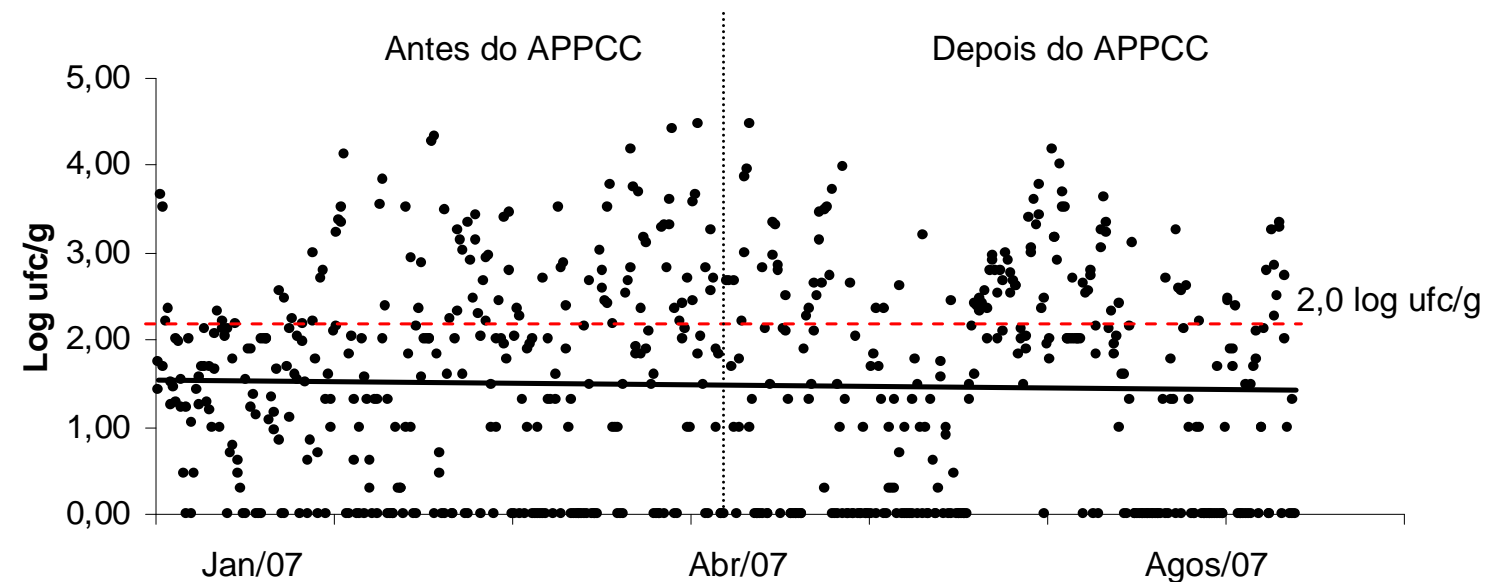

Figura 10 - Dispersão das contagens de coliformes totais (log ufc/g) nas amostras de iogurte analisadas antes e depois da implantação do APPCC. 
A Figura 11 apresenta a distribuição dos valores de coliformes fecais, e de forma semelhante ao caso anterior, não foi encontrada diferença estatística entre os dois períodos $(P=0,928)$. Verifica-se que esses microrganismos estiveram ausentes na maior parte das amostras analisadas, com algumas contaminações esporádicas que ultrapassaram o limite máximo permitido (1,0 log ufc/g).

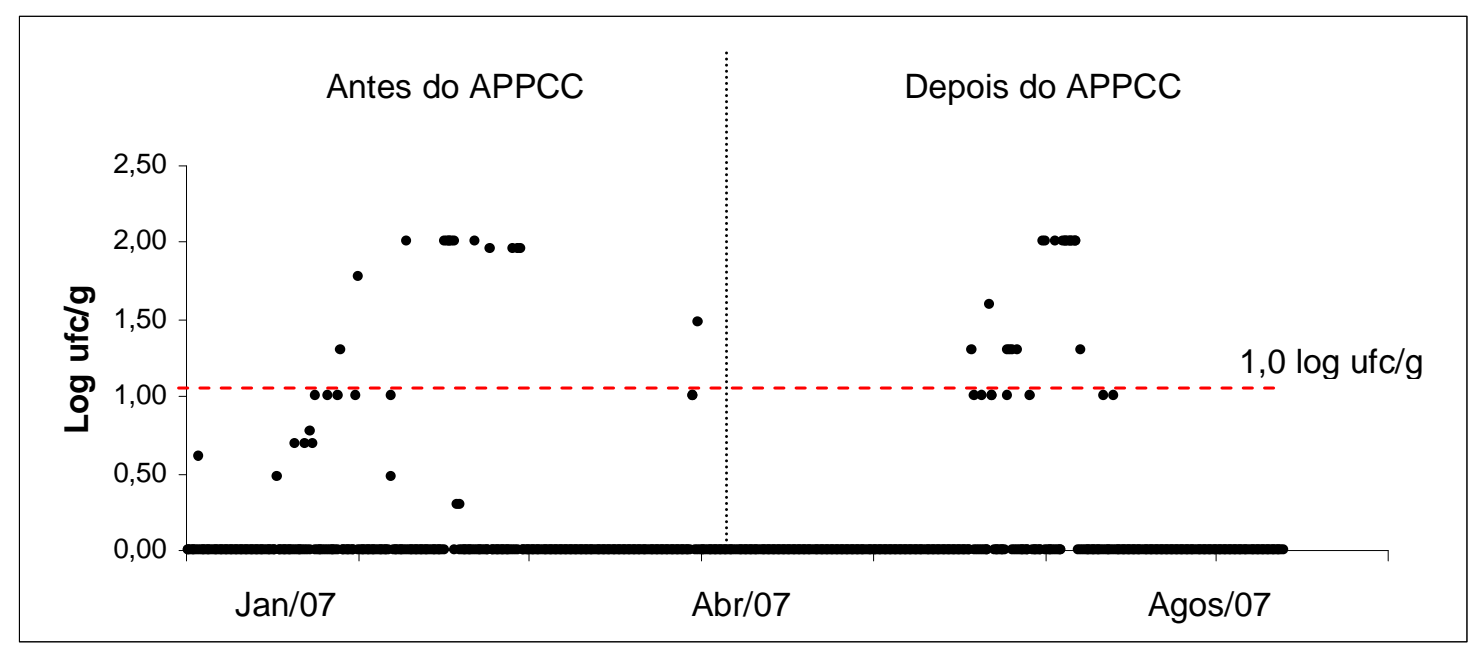

Figura 11 - Dispersão das contagens de coliformes fecais (log ufc/g) nas amostras de iogurte analisadas antes e depois da implantação do APPCC.

Os microrganismos aqui analisados são característicos de contaminações ambientais e a presença constante destes no produto acabado é um indicativo de falhas na higiene dos manipuladores durante o processamento, bem como de falhas na higienização dos equipamentos.

O resultado é condizente com as falhas de higiene identificadas no monitoramento dos PCCs relativos ao envase e à higienização de equipamentos. O fato pode ser justificado pela rotatividade de funcionários até o mês de Junho, impedindo que os treinamentos surtissem o efeito desejado e que fosse atingido um padrão de higiene adequado durante a produção do iogurte.

A ausência de um programa de treinamento rotineiro, identificada no diagnóstico inicial do laticínio, também tornou mais lenta a mudança de comportamento dos funcionários. 
A redução na contagem de bolores e leveduras demonstra que a aplicação do APPCC teve um efeito positivo sobre a qualidade microbiológica do produto acabado, sugerindo que com a continuidade dos treinamentos e monitoramentos dos PCCs as contaminações podem ser ainda menores ao longo do tempo.

\subsubsection{Perdas de embalagens na linha de produção}

Na Tabela 8 são apresentadas médias das perdas de embalagens antes e após a implantação do APPCC.

Tabela 8 - Percentuais das perdas de garrafas, rótulos e tampas ${ }^{1}$ ocorridas na linha de produção, antes e após a implantação do APPCC ${ }^{2}$

\begin{tabular}{cccc}
\hline & $\begin{array}{c}\text { Perdas de garrafas } \\
(\%)\end{array}$ & $\begin{array}{c}\text { Perdas de rótulos } \\
(\%)\end{array}$ & $\begin{array}{c}\text { Perdas de tampas } \\
(\%)\end{array}$ \\
\hline Antes APPCC & $0,93 \pm 0,51^{\mathrm{a}}$ & $0,80 \pm 0,42^{\mathrm{b}}$ & $2,02 \pm 1,26^{\mathrm{a}}$ \\
Depois APPCC & $0,80 \pm 0,40^{\mathrm{a}}$ & $1,01 \pm 0,68^{\mathrm{a}}$ & $2,44 \pm 1,45^{\mathrm{a}}$ \\
\hline${ }^{1}$ - Resultados relativos à média \pm desvio padrão dos percentuais de perdas nos períodos. \\
${ }^{2}$ - Análise de perigos e pontos críticos de controle.
\end{tabular}

Com relação à perda de garrafas, apesar de uma redução nominal de 0,13\%, não foi encontrada diferença estatística entre as perdas antes e após a implantação do APPCC (P=0,056). Os valores predominaram entre 0,5 e 1,0\%, ao longo do período, com discreta tendência de queda, conforme se observa na distribuição das perdas diárias de garrafas na linha de produção apresentada na Figura 12. 


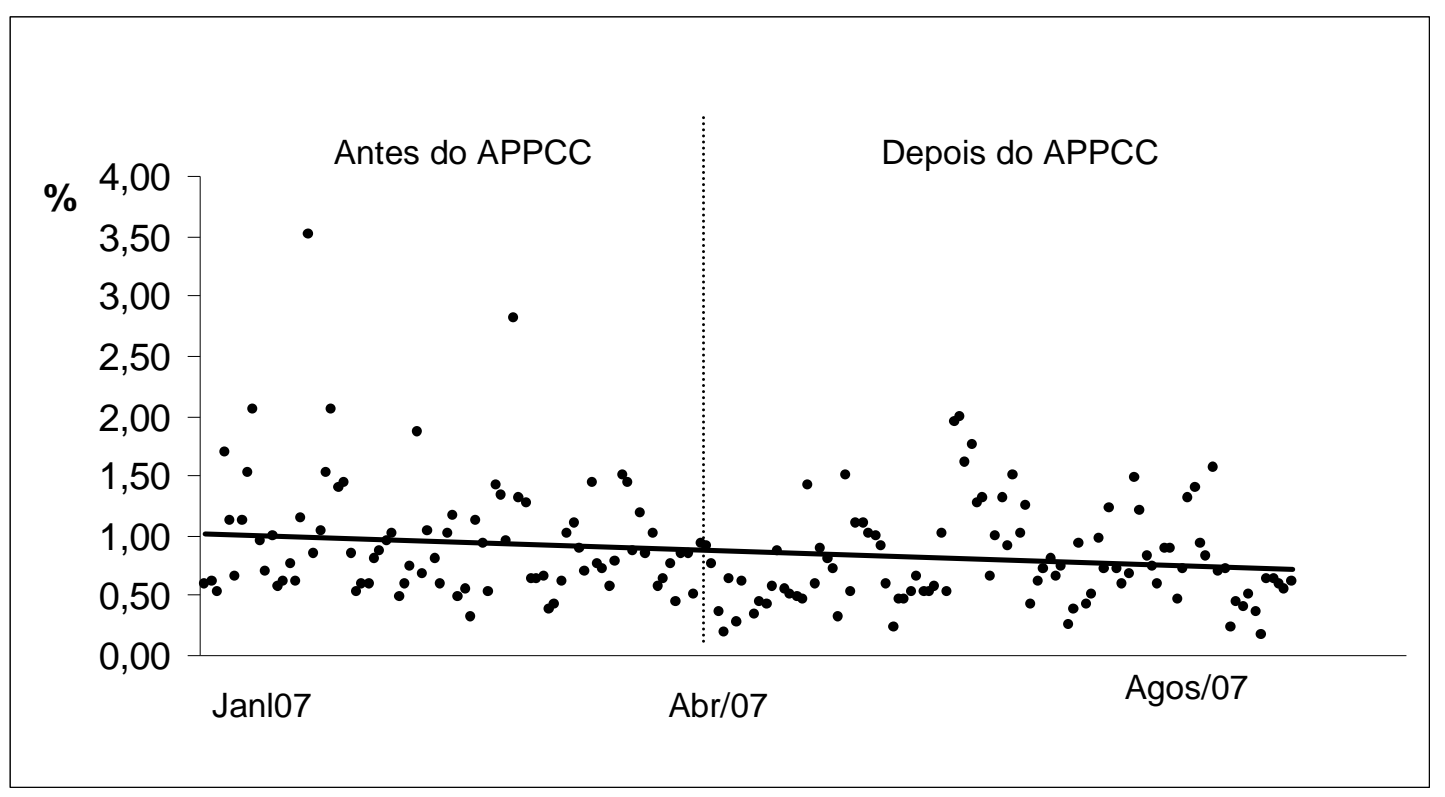

Figura 12 - Percentuais de perdas diárias de garrafas na linha de produção de iogurte, antes e depois da implantação do APPCC.

Essa tendência pode ser melhor visualizada na Figura 13, onde são apresentadas as médias mensais de perda de garrafas de Janeiro a Maio. Neste período, as perdas mensais decresceram de $1,1 \%$ para $0,6 \%$, sofrendo um aumento no mês de Junho e voltando a cair até o final do período, em Agosto. 


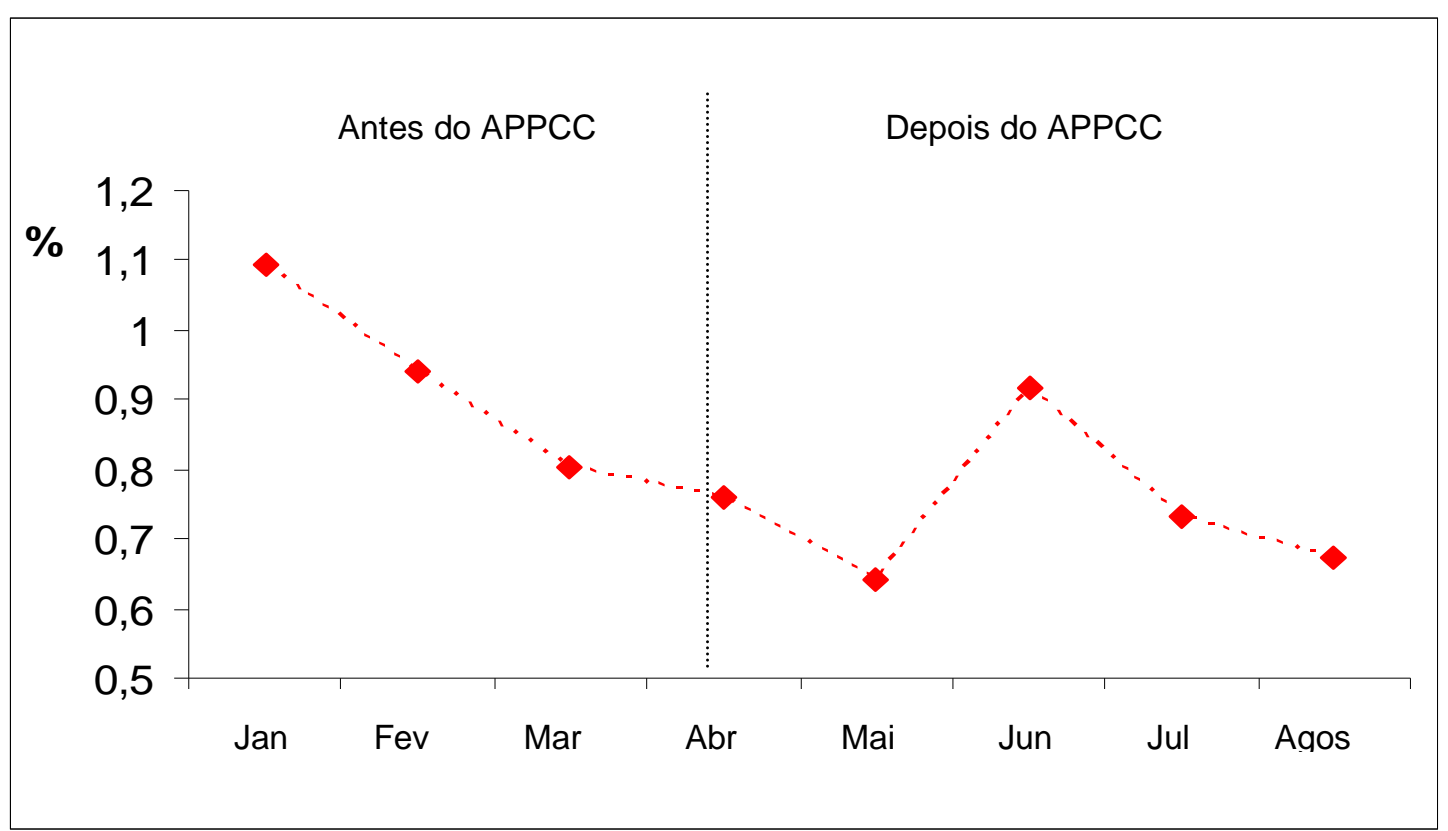

Figura 13 - Percentuais de perdas mensais de garrafas na linha de produção de iogurte, antes e depois da implantação do APPCC.

As perdas diárias de tampas são apresentadas na Figura 14. Observa-se grande amplitude entre os valores ao longo do tempo, variando entre 0,5 a 3,0\% de perdas. Da mesma forma que no caso anterior, não foi encontrada diferença estatística entre as médias das perdas antes e após a implantação do APPCC $(P=0,067)$. 


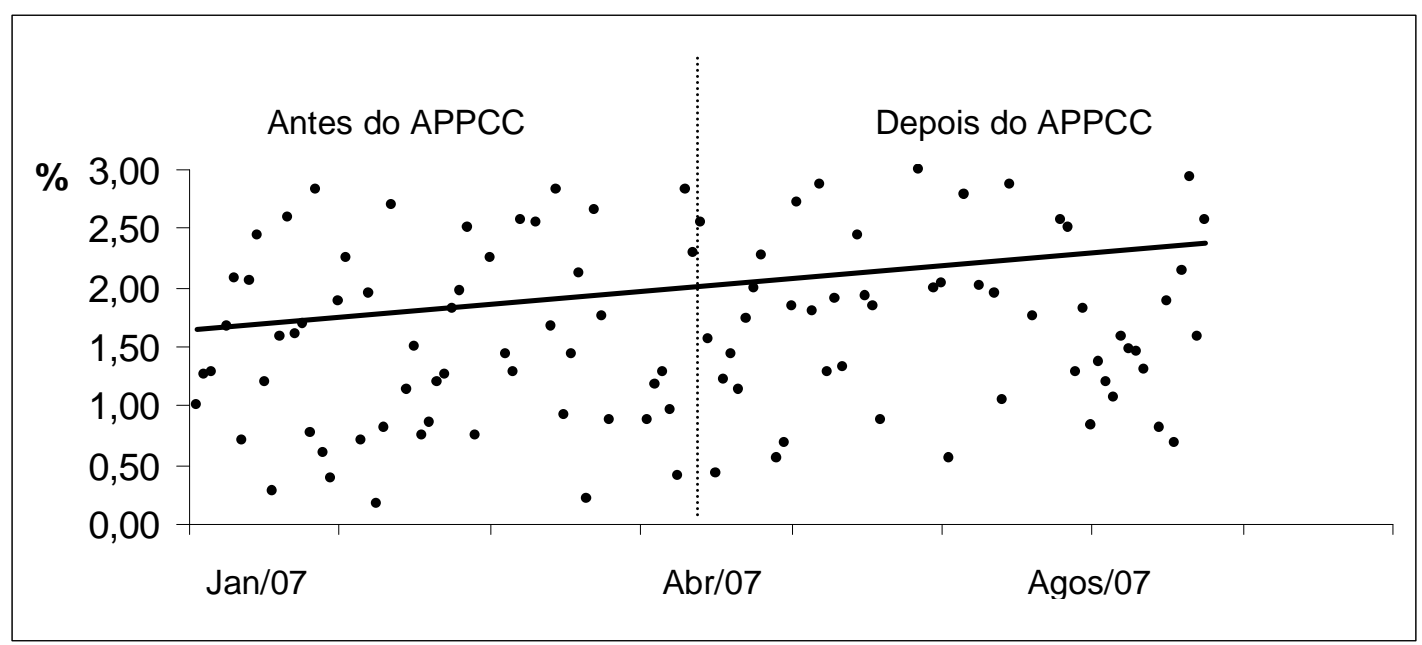

Figura 14 - Percentuais de perdas diárias de tampas na linha de produção de iogurte, antes e depois da implantação do APPCC.

Na Figura 15 são apresentadas as médias mensais de perdas de tampas e pode-se observar uma variação entre 1,5 e 2,5\%, com um aumento expressivo no mês de junho.

Esse item de embalagem foi o que apresentou o maior índice de perdas, decorrentes de não conformidades quanto às especificações de tamanho, as quais foram identificadas nos monitoramentos. Vale ressaltar que, pelo fato de ser o último item a ser adicionado à embalagem na linha de produção, muitas vezes as perdas de tampas provocaram também perdas de garrafas e rótulos, além de expor o iogurte a contaminações ambientais pelo maior manuseio das embalagens ainda abertas. 


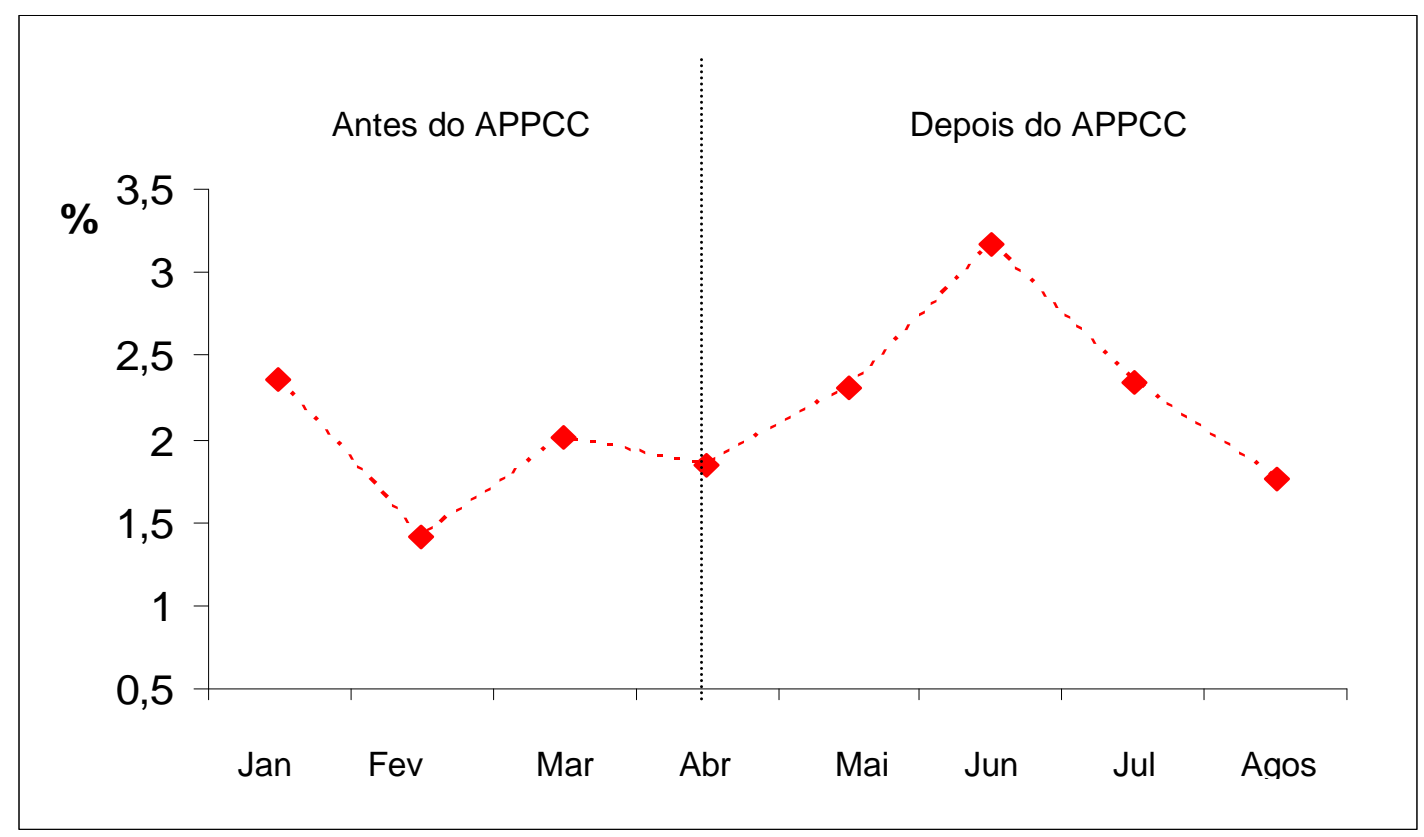

Figura 15 - Percentuais de perdas mensais de tampas na linha de produção de iogurte, antes e depois da implantação do APPCC

As perdas de rótulos são apresentadas na Figura 16. Foi encontrada diferença estatística entre as médias $(P<0,05)$, com aumento após a implantação do APPCC.

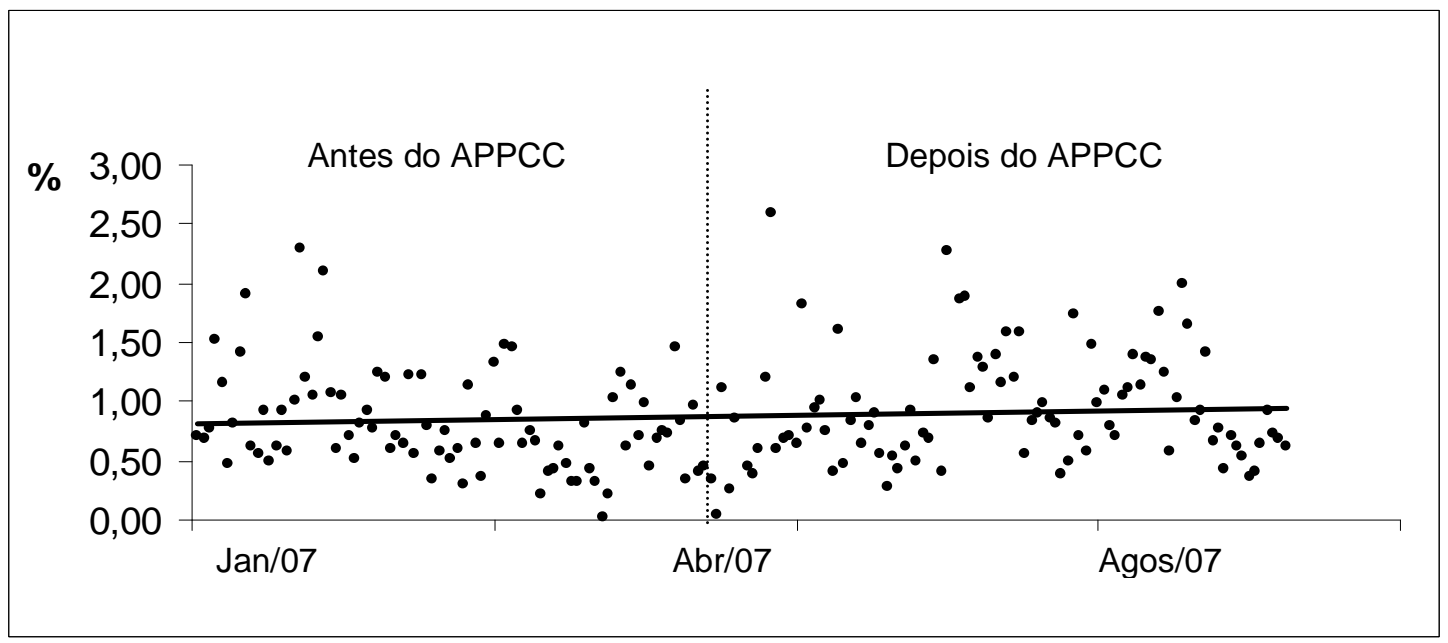

Figura 16 - Percentuais de perdas diárias de rótulos na linha de produção de iogurte, antes e depois da implantação do APPCC. 
Na Figura 17 verifica-se que as perdas mensais sofreram uma redução de Janeiro a Maio, chegando a $0,6 \%$ no mês de Março, mas, da mesma forma que as outras embalagens apresentou um aumento no mês de Junho, voltando a decrescer até o final do período.

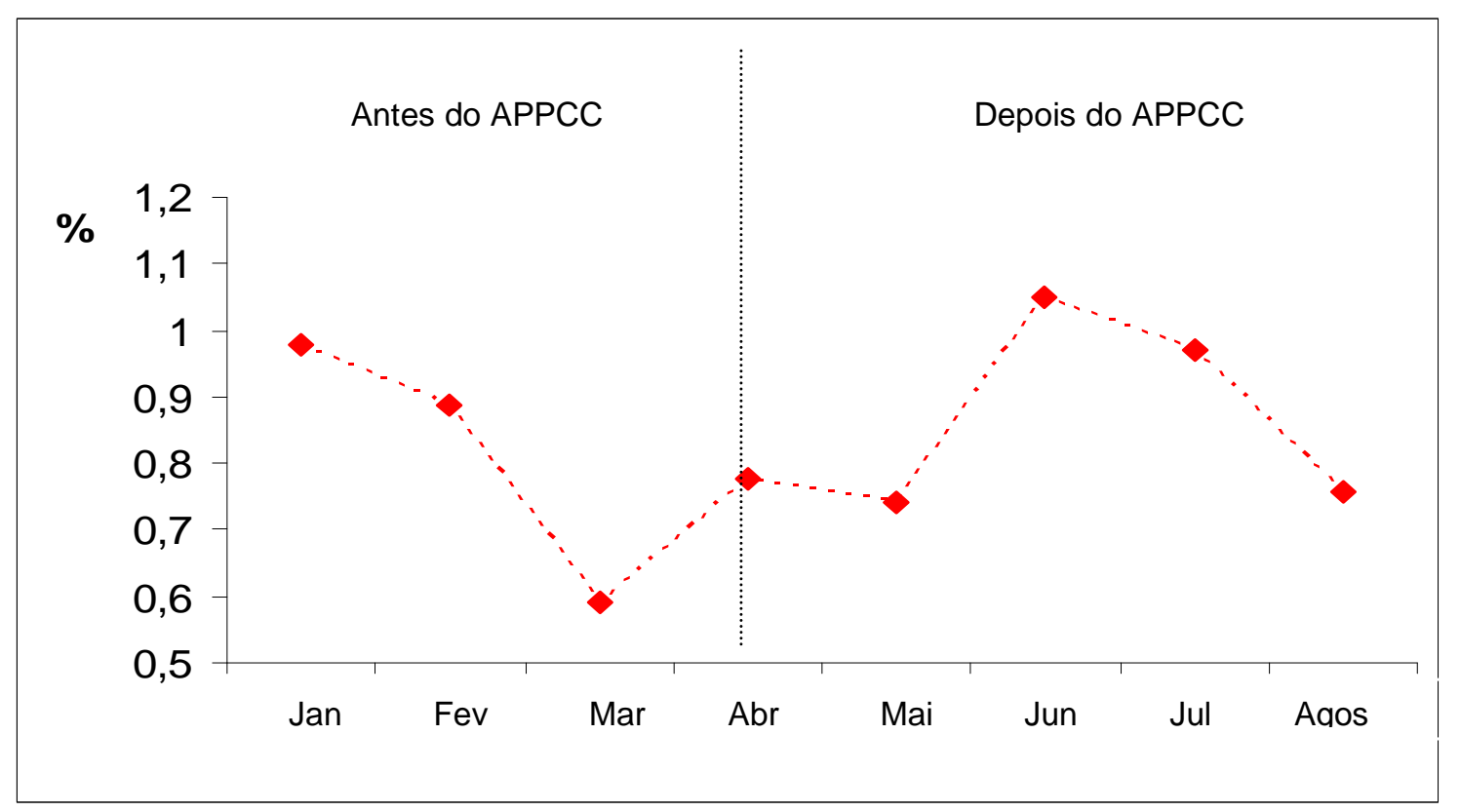

Figura 17 - Percentuais de perdas mensais de rótulos na linha de produção de iogurte, antes e depois da implantação do APPCC.

Os resultados encontrados para as perdas nos três tipos de embalagens são decorrentes das falhas no controle da qualidade do material recebido, onde a falta de ações corretivas diante das não conformidades encontradas para esses itens permitiu que embalagens fora do padrão chegassem à linha de produção. Acrescenta-se a esse fato o melhor treinamento dos funcionários responsáveis pela seleção das embalagens no momento do envase, impedindo que as falhas prosseguissem na linha de produção, contribuindo para elevar as perdas de rótulo e mantendo as perdas de tampas e garrafas ao longo do período estudado.

O monitoramento do PCC relacionado ao recebimento de embalagens identificou, através das auditorias, falhas no controle de qualidade existentes na planta do fornecedor, permitindo que os defeitos chegassem até o laticínio. Este, por sua vez não realizou um controle eficiente do material recebido ou quando o 
fez, não aplicou as ações corretivas adequadas, resultando nos níveis de perdas encontrados.

O aumento de tais perdas implica em aumento de custos de produção, e pode resultar em maior índice de devoluções do produto acabado pelos clientes e insatisfação do consumidor, caso esses defeitos cheguem ao comércio.

Rótulos rasgados, garrafas amassadas e mal seladas são algumas das conseqüências de defeitos das embalagens, que podem provocar devoluções do comércio, refletindo-se nos custos de produção. Acrescenta-se a esses custos o valor do iogurte perdido nestas condições.

A perda mensal média de embalagens, apurada no período de Janeiro a Agosto, foi de $R \$ 2.076,54$, representando $R \$ 0,01 / \mathrm{kg}$ de iogurte embalado ou $0,5 \%$ do custo de quilo.

Deve-se salientar que quando a qualidade das matérias primas e embalagens são controladas adequadamente ainda no fornecedor, a condução do APPCC é facilitada, com redução de tempo e custo para os monitoramentos.

De acordo Bauman (1990), em certas situações, deve-se auxiliar os fornecedores a estabelecer programas de controles de qualidade em suas plantas. O fato do controle de estoque de embalagens apresentado pelo laticínio ser just in time, com estoques mínimos, aumenta a necessidade de um controle de qualidade mais rigoroso por parte do fornecedor.

Dentre as principais dificuldades encontradas na implantação do APPCC destacam-se a falta de rapidez nas ações corretivas, sobretudo quando estas estavam relacionadas à necessidade de investimentos e a uma postura mais firme frente aos fornecedores. A demora ou ausência para tais ações contribuíram para a menor efetividade do plano. Acrescenta-se ainda como dificuldade, a necessidade de treinamentos constantes e obtenção do comprometimento dos funcionários, que permitisse mudança mais permanente na conduta e hábitos higiênicos. 


\section{CONCLUSÃO}

Considerando os resultados encontrados neste trabalho, conclui-se que:

- O sistema APPCC contribuiu de forma positiva para a melhora da qualidade microbiológica do iogurte, com relação à presença de bolores e leveduras. As contagens de coliformes totais e fecais, no entanto, não foram alteradas e o padrão microbiológico do produto acabado, ao final do trabalho, sugere a necessidade de treinamento continuado dos funcionários para que os benefícios do sistema possam ser mais efetivos.

- Com relação às perdas de embalagens, não houve alteração significativa com a implantação do sistema, uma vez que os monitoramentos e as medidas corretivas não foram realizados na sua totalidade.

- Com relação aos custos envolvidos na implementação do APPCC pode-se concluir que estes são sensivelmente reduzidos quando os programas prérequisitos são implementados previamente e quando a equipe responsável pelo APPCC pode ser treinada para elaborar o plano, sem recorrer à consultoria externa. Neste estudo, a redução seria de $22 \%$ nos custos de implantação do APPCC caso os programas pré-requisitos estivessem devidamente implantados.

- A implementação do plano representou $R \$ 0,02 / \mathrm{kg}$ de iogurte embalado e os três maiores custos dessa etapa foram relativos à consultoria externa, adequação aos programas pré-requisitos e aquisição de equipamentos e mudanças estruturais.

- A manutenção do APPCC representou $R \$ 0,01 / \mathrm{kg}$ de iogurte embalado e os maiores gastos dessa etapa foram relativos aos monitoramentos e material de laboratório. Assim, o custo total do APPCC representou $R \$ 0,03 / \mathrm{kg}$ de iogurte embalado ou $1,5 \%$.

- Finalmente, pode-se concluir que a aplicação do APPCC para a linha de produção de iogurte apresenta relação custo-benefício satisfatória, por se tratar de um produto sensível às variações no processamento e pelo fato do sistema conseguir controlar de forma eficiente tais variações, garantindo o padrão de qualidade do produto e conseqüente satisfação do consumidor. 


\section{REFERÊNCIAS BIBLIOGRÁFICAS}

ALMEIDA, C.R. O Sistema HACCP como instrumento para garantir a inocuidade dos alimentos. Revista Higiene Alimentar, São Paulo, v.12, n.53, p. 12-20, 1998.

ALMEIDA, G.D. et al. Produção de refeições em creche: recursos para a implementação das boas práticas de higiene e manipulação de alimentos, em busca de qualidade. Revista Higiene Alimentar, São Paulo, v.16, n.94, p.26-29, mar. 2002.

ANUÁRIO BRASILEIRO DA PECUÁRIA 2007. Santa Cruz do Sul: Gazeta Santa Cruz, 2007.

BATA, D. et al. Cost of GHP improvement and HACCP adoption of na airline catering company. Food Control, Guildford, v.17, n. 5, p.414-419, 2006.

BAUMAN, H. HACCP: concept, development, and application. Food Technology, Champaign, v.44, n.5, p.156-159, 1990.

BAUMAN, H.E. The origin and concept of HACCP. In: PEARSON, A.M.; DUTSON, T.R. HACCP in meat, poultry and fish processing. London: Chapman \& Hall, 1995. p.1-7.

BELLIZI, A. et al. Treinamento de manipuladores de alimentos: uma revisão de literatura. Revista Higiene Alimentar, São Paulo, v. 19, n.133, p.36-48, jul. 2005.

BORNIA, A.C. Análise gerencial de custos. Porto Alegre: Bookman, 2002.

BRASIL. M. S. Resolução RDC n. 275, de 21 de outubro de 2002. Dispõe sobre o regulamento técnico de procedimentos operacionais padronizados aplicados aos estabelecimentos produtores/ industrializadores de alimentos e a lista de verificação das boas práticas de fabricação em estabelecimentos produtores /industrializadores de alimentos. Diário Oficial da União, Brasília, 23 out. 2002. Seção I, p.126. 
BRASIL. M. A. A. Portaria n.46 de 10 de fevereiro de 1998. Institui o Sistema de Análise de Perigos e Pontos Críticos de Controle - APPCC a ser implantado, gradativamente, nas indústrias de produtos de origem animal sob o regime do serviço de inspeção federal - SIF, de acordo com o manual genérico de procedimentos. Diário Oficial da União, Brasília, 16 mar.1998. Seção I, p.24.

BRASIL. M. S. Portaria n.1428 de 26 de novembro de 1993. Regulamento técnico para inspeção sanitária de alimentos. Diário Oficial da União, Brasília, 2 dez. 1993. Seção I.

BRASIL. M.A.P.A. Resolução n.5 de 13 de novembro de 2000. Oficializa os Padrões de Identidade e Qualidade (PIQ) de leites fermentados. Diário Oficial da União, Brasília, 27 nov. 2000. Seção I, p.9.

BRASIL. M.A.P.A. Resolução n.10 de 22 de maio de 2003. Institui o Programa Genérico de Procedimentos - Padrão de Higiene Operacional - PPHO, a ser utilizado nos estabelecimentos de leite e derivados que funcionam sob o regime de Inspeção Federal, como etapa preliminar e essencial dos Programas de Segurança Alimentar do tipo APPCC (Análise de Perigos e Pontos Críticos de Controle). Diário Oficial da União, Brasília, 28 maio 2003. Seção I, p.4.

BRYAN, F.L. Aplicação do método de análise de risco por pontos críticos de controle, em cozinhas industriais. Revista Higiene Alimentar, São Paulo, v. 7, n. 25, p. 15-22, mar. 1993.

BUCHWEITZ, M.; SALAY, E. Analysis of implementation and cost of HACCP system in foodservices industries in the county of Campinas, Brazil.

Disponível em: <http://www.umass.edu/ne165/haccp1998/buchweitz.html>. Acesso em: 18 mar. 2006.

BUCHWEITZ, M.R.D. Normas boas práticas de produção e de prestação de serviços e sistema análise de perigos e pontos críticos de controle em serviços de alimentação na região de governo de Campinas: situação da implementação e custos. 2001. Tese (Doutorado em Ciência da Nutrição) Faculdade de Engenharia de Alimentos, Universidade Estadual de Campinas, Campinas, 2001.

BUENO, V.F.F. et al. Influência da temperatura de armazenamento e do sistema de utilização do tanque de expansão sobre a qualidade microbiológica do leite cru. Revista Higiene Alimentar, São Paulo, v. 18, n. 121, p. 62-67, set. 2001. 
CARVALHO, M.P. Perspectivas brasileiras no comércio mundial de lácteos. In: ANUALPEC - Anuário da Pecuária Brasileira. São Paulo: FNP, 2004.

CASWELL, J.A. Economic aproaches to measurig the significance of food safety in internacional trade. Internacional Journal of Food Microbiology, Amsterdan, v. 62, p.261-266, 2000.

CEZARI, D.L.; NASCIMENTO, E.R. Análise de perigos e pontos críticos de controle: manual. Rio de Janeiro: SBCTA, 1995. (Série Qualidade).

CORLETT JUNIOR., D.A. HACCP user's manual. Maryland: Aspen Publishers, 1998.

COSTA JUNIOR.,G.A. Brazil's Implementation of HACCP Programs. In: MARTIN, E.R; COLLETTE, R.L.; SLAVIN, J.W. Fish inspection, quality control and HACCP: a global focus. Virginia: Technomic, 1997.

CULLOR., J.S. HACCP (Harzard Analysis Critical Control Points): is it coming to the dairy?. Journal of Dairy Science, Savoy, v.80, n.12, p.3449-3452, 1997.

DEMING, W.E. Qualidade: a revolução da administração. Rio de Janeiro: Marques Saraiva, 1990.

DONOVAN, J.A.; CASWELL, J.A.; SALAY, E. The effect of stricter foreign regulations on food safety levels in developing countries: a study of Brazil. Review of Agricultural Economics, v.23, n.1, p.163-175, 2001.

EHIRI, J.E.; MORRIS, G.P.; McEWEN, J. Implementation of HACCP in food businesses: the way ahead. Food Control, Guildford, v.6, n.6, p.341-345, 1995.

EVANGELISTA, J. Tecnologia de alimentos. 2.ed. São Paulo: Atheneu, 2001.

FEIGENBAUM, A.V. Controle da qualidade total: aplicações nas empresas. São Paulo: Makron Books, 1994. v.4. 
FIGUEIREDO, R.S. Sistemas de apuração de custos. In: BATALHA, M.O. Gestão agroindustrial. 2.ed. São Paulo: Atlas, 2001. p.381-464.

FLOWERS, R.S. et al. Pathogens in milk and milk products. In: MARSHAL, R.T. Standard methods for the examination of dairy products. Washington: American Public Health Association, 1993.

FONSECA, L.F.L.; PEREIRA, C.C.P.; CARVALHO, M.P. Qualidade microbiológica do leite. In: SIMPÓSIO INTERNACIONAL SOBRE PRODUÇÃO INTENSIVA DE LEITE. 4, 1999, Caxambu. Anais..São Paulo: Instituto Fernando Costa, 1999.

FORSYTHE, S.J. Microbiologia da segurança alimentar. Porto Alegre: Artmed, 2002.

FRANCO, B. D. G. M.; LANDGRAF, M. Microrganismos patogênicos de importância em alimentos. In: FRANCO, B.D.G.M.; LANDGRAF, M. Microbiologia dos alimentos. São Paulo: Atheneu, 2003.

FREIRE, P. Pedagogia da autonomia: saberes necessários à pratica educativa. São Paulo: Paz e Terra, 2006. 148p.

FUJIHARA, M. R.; SYLVIO, S. B. Limpeza e desinfecção de plantas de processamento. In: CONTRERAS et al. Higiene e sanitização na indústria de carnes e derivados. São Paulo: Varela, 2002.

GACULA, J.R.; SINGH, J. Statistical methods in food and consumer research. Orlando: Academic Press, 1984.

GERMANO, M.I.S. Treinamento de manipuladores de alimentos: fator de segurança alimentar e promoção da saúde. São Paulo: Varela, 2003a.

Treinamento e desenvolvimento de recursos humanos. In: Higiene e vigilância sanitária de alimentos. 2.ed. São Paulo: Varela, 2003b.

GÓES, J.A.W. et al. Capacitação dos manipuladores de alimentos e a qualidade da alimentação servida. Revista Higiene Alimentar, São Paulo, v.15, n.82, p. 2022, 2001. 
GRYNA, F.M. Custos da qualidade. In: Controle da qualidade: conceitos, políticas e filosofia da qualidade. São Paulo: Makron/McGraw-Hill, 1991.

GUIMARÃES, R. Importância da matéria prima para a qualidade do leite de consumo. Revista Higiene Alimentar, São Paulo, v.16, n. 102/103, p 25-34, nov/dez. 2002.

HAJDENWURCELL, J.R. A experiência da indústria de laticínios na implantação do APPCC: Estudo de caso. Revista Indústria de Laticínios, São Paulo, p.2431, jul/ago, 2002.

HAYES, P.R. Food microbiology and hygiene. 2.ed. London: Chapman e Hall, 1995.

HAYES, M. C.; BOOR, K. Raw milk and fluid milk products. In: MARTH, E.H.; STEELE, J.L. Applied dairy microbiology. 2. ed. New York: Marcel Dekker, 2001.

HARDING, F. Higienic quality. In: HARDING, F. Milk quality. Maryland: Aspen Publishers, 1999.

HARMON, R. Mastitis and milk quality. In: HARDING, F. Milk quality. Maryland: Aspen Publishers, 1999.

HAZELWOOD D.; McLEAN, A.C. Manual de higiene para manipuladores de alimentos. São Paulo: Varela, 1994. 140p.

HEESCHEN, W.; HARDING, F. Contaminants. In: HARDING, F. Milk quality. Maryland: Aspen Publishers, 1999.

HENSON, S.; HOLT, G.; NORTHEN, J. C. Cost and benefits of implementing HACCP in the UK dairy processing sector. Food Control, Guildford, v.10, p.99106, 1999. 
INTERNATIONAL COMMISSION ON MICROBIOLOGICAL SPECIFICATIONS FOR FOODS. El sistema de análisis de riesgos y puntos críticos: Su aplicación a las industrias de alimentos. Zaragoza: Acribia, 1991.

IUDÍCIBUS, S.; MARION, J.C. Curso de Contabilidade para não contadores. 2.ed. São Paulo: Atlas, 2000

JURAN, J.M. A função qualidade. In: JURAN, J.M. Controle da Qualidade: conceitos, políticas e filosofia da qualidade. São Paulo: Makron/McGraw-Hill, 1991.

Juran planejando para a qualidade. São Paulo: Pioneira, 1990.

A qualidade desde o projeto: Novos passos para o planejamento da qualidade em produtos e serviços. São Paulo: Pioneira, 1992.

LANARA - Laboratório Nacional de Referência Animal. Métodos analíticos oficiais para controle de produtos de origem animal e seus ingredientes. Brasília: Ministério da Agricultura, 1981.

LARANJA-FONSECA, L. F. Qualidade do leite e sua relação com equipamento de ordenha e sistema de resfriamento. In: SIMPOSIO INTERNACIONAL SOBRE QUALIDADE DO LEITE, 1., 1998, Curitiba. Anais... Curitiba: Biblioteca da UFPR, 1998. p. 54-56.

LEITÃO, M.F.F. Análise de Perígos e Pontos Críticos de Controle na Indústria de Alimentos. In: SEMINÁRIO SOBRE QUALIDADE NA INDÚSTRIA DE ALIMENTOS. Campinas: ITAL, 1993. p. 100-110.

MAKIYA, I.K.; ROTONDARO, R.G. Integração entre os sistemas GMP /HACCP /ISSO 9000 nas indústrias de alimentos. Revista Higiene Alimentar, São Paulo, v.16, n.99, p.46-50, 2002.

MALDONADO, E.S. et al. Cost-benefit analysis of HACCP implementation in the Mexican meat industry. Food Control, Guildford, v.16, p.375-381, 2005. 
MARTHI, B. HACCP implementation: The Indian experience. In: MAYES, T.; MORTIMORE, S. Making the most of HACCP: learnig from others' experience. England: Woodhead, 2003. p.81-97.

MARTINS, E. Contabilidade de custos. São Paulo: Atlas, 1996.

MAYES, T. HACCP training. Food Control, Guildford, v.5, n.3, p.190-195, 1994.

MAYES, T.; MORTIMORE. S. Making the most of HACCP: learnig from others' experience. England: Woodhead, 2003.

McALOON, T.R. HACCP implementation in the United States. In: MAYES, T.; MORTIMORE, S. Making the most of HACCP: learnig from others' experience. England: Woodhead, 2003. p.61-80.

MISTRY, V. V. Fermented milks and cream. In: MARTH, E.H.; STEELE, J.L. Applied dairy microbiology. 2. ed. New York: Marcel Dekker, 2001.

MÔNACO, G.M. Meta é tornar-se também grande exportador de leite. In: ANUALPEC - Anuário da pecuária brasileira. São Paulo: FNP, 2005.

MORTIMORE, S.; WALLACE, C. HACCP - a practical approach. Maryland: Aspen, 1998.

MOTARJEMI, Y; KÄFERSTEIN, F. Food safety, harzard analysis and critical control point and the increase in foodborne diseases: a paradox?. Food Control, Guildford, v.10, p. 325-333, 1999.

OLIVEIRA, C.A.F.; FONSECA, L.F.L.; GERMANO, P.M.L. Aspectos relacionados à produção, que influenciam a qualidade do leite. Revista Higiene Alimentar, São Paulo, v.13, n.62, p.10-16, 1999.

PHILPOT, W.N. Qualidade do leite e controle de mastite: passado, presente e futuro.In: CONGRESSO PANAMERICANODE QUALIDADE DO LEITE E CONTROLE DE MASTITE, 2., 2002, Ribeirão Preto. Anais... São Paulo: Instituto Fernando Costa, 2002. p.23-38. 
ROBERTO, C.D.; BRANDÃO, S.C.C; da SILVA, C.A.B. Cost and investiments of implementing and maintaining HACCP in pasteurized milk plant. Food Control, Guildford, v.17, n. 8, p.599-603, 2006.

ROBINSON, R.K.; TAMINE, A.Y. Recent developments in yoghurt manufacture. In: ROBINSON, R.K. Modern dairy technology. London: Elsevier Applied Science Publishers, 1986. v.2.

ROSENTHAL, I. Milk and dairy products: properties and processing. Weinheim: Balaban, 1991.

RUEGG, P.L. Practical food safety intervention for dairy production. Jounal of Dairy Science, Savoy, v.86, suppl., p.E1-E9, 2003.

SANTOS, M.V.; LARANJA, L.F.F. Importância e efeito de bactérias psicrotróficas sobre a qualidade do leite. Revista Higiene Alimentar, São Paulo, v.15, n.82, 2001.

SENAI. Guia para elaboração do plano APPCC: geral. 2.ed. Brasília: SENAI/DN, 2000.

SILVA, J.A. As novas perspectivas para o controle sanitário dos alimentos. Revista Higiene alimentar, São Paulo, v.13, n. 65, p19-25, 1999.

SILVA JUNIOR, E.A. Manual de controle higiênico-sanitário em alimentos. São Paulo: Varela, 2002.

SOUZA, L.H.L. A manipulação inadequada dos alimentos: fator de contaminação. Revista Higiene Alimentar, São Paulo, v.20, n.116, 2006.

SPREER, E. Lactología industrial. Zaragoza: Acribia, 1991. . Milk and dairy product tecnology. New York: Marcel Dekker, 1998.

STAFF, M.C. Leches fermentados y quesos frescos. In: EARLY, R. Tecnología de los productos lácteos. Zaragoza: ACRIBIA, 2000. 
STANLEY, G. Microbiologia de los productos lácteos fermentados. . In: EARLY, R. Tecnología de los productos lácteos. Zaragoza: Acribia, 2000.

STEVENSON, K.E. Implementing HACCP in fhe food industry. Food Technology, Champaign, v. 44, n.5, p.179-180, 1990.

SUWANRANGSI, S. HACCP implementation in thai fisheries industry. Food Control, Guildford, v.11, p. 377-382, 2000.

TAMINE, A.Y.; ROBINSON, R.K. Yogurt: ciência y tecnologia. Zaragoza: Acribia, 1991.

TAYLOR, E. HACCP and SMEs: problems and opportunities. In: MAYES, T.; MORTIMORE, S. Making the most of HACCP: learnig from others' experience. England: Woodhead, 2003. p.13-31.

TOLEDO, J.C. Gestão da qualidade na agroindústria. In: BATALHA, M.O. Gestão agroindustrial. São Paulo: Atlas, 2001. p.466-517.

UNNEVEHR, L.; ROBERTS, T. Improving cost/benefit analysis for HACCP and microbial food safety: An economist's overview. In: CASWELL, J.A..; COTTERILL, R.W. Strategy and policy in the food system: emerging issues. Washington: Univ. Conecticut/Univ. Massechucets, 1996. p.225-229.

VARNAM, A.H.; SUTHERLAND, J.P. Leche y productos lácteos: tecnología, química y microbiología. Zaragoza: Acribia, 1994.

Milk and milk products: technology, chemistry and microbiology. London: Charpman \& Hall, 1996.

VEISSEYRE, R. Lactologia técnica: composición, recogida, tratamiento y transformación de la leche. Zaragoza: Acribia, 1988.

WALLACE, C.; WILLIAMS, T. Pré-requisites: a help or a hindrance to HACCP?. Food Control, Guildford, v.12, n.4, p.235-240, 2001. 
WALSTRA, P. et al. Ciencia de la leche y tecnologia de los productos lácteos. Zaragoza: Acribia, 2001.

WORLD HEALTH ORGANIZATION. Food safety and foodborne illness. 2007. Disponivel em: <http://www.who,int/foodsafety/foodborne_disease/in/>. Acesso em: 01 maio 2007. 
ANEXOS 


\section{ANEXO A - Planta esquemática do laticínio}

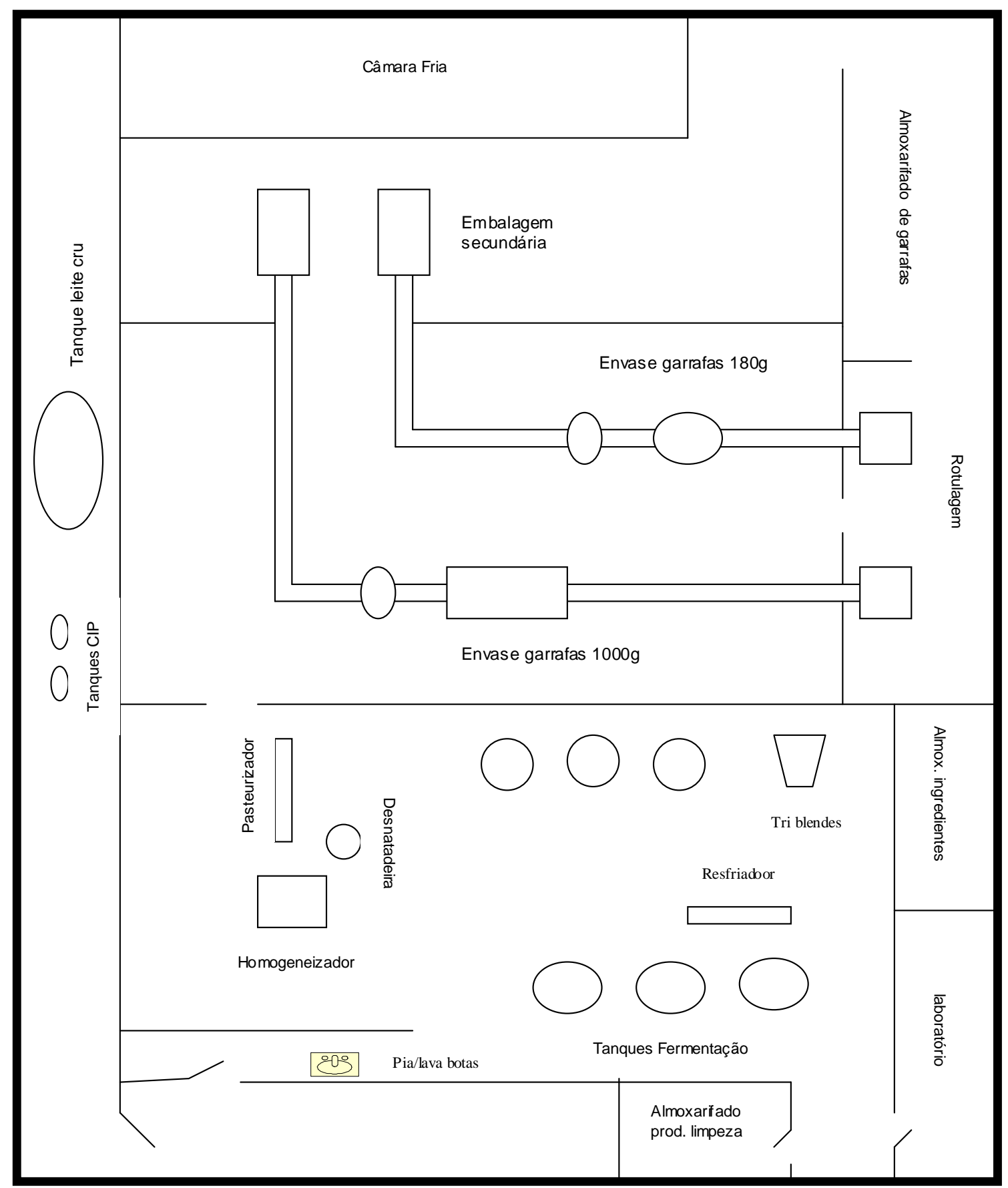




\section{ANEXO B - Questionário aplicado aos funcionários antes do treinamento em Boas Práticas de Fabricação (BPF)}

Data

Questionário

Por favor, responda às seguintes perguntas:

1.Cargo ou função que ocupa na empresa

R.

2. Há quanto tempo você trabalha na empresa?

R.

3. Você já trabalhou em algum outro laticínio anteriormente?

R.

4. Quando ingressou na empresa, você recebeu algum tipo de treinamento com relação ao trabalho que realizaria?

R.

5. Você sabe o que é contaminação alimentar?

R.

6. Você sabe ou já ouviu falar em Boas Práticas de Fabricação? Em caso afirmativo, já recebeu algum treinamento sobre esse assunto?

R. 
ANEXO C - Modelo Geral de uma Instrução de Trabalho para PPHO - Higienização das Mãos dos Manipuladores

\begin{tabular}{|c|c|c|}
\hline \multirow{3}{*}{$\begin{array}{l}\text { Logo } \\
\text { da Empresa }\end{array}$} & \multirow{2}{*}{$\begin{array}{l}\text { PROCEDIMENTO PADRÃO DE } \\
\text { HIGIENE OPERACIONAL }\end{array}$} & Código: PPHO-009 \\
\hline & & Revisão: 0 \\
\hline & INSTRUÇÃO DE TRABALHO & Emissão : 08/11/06 \\
\hline LOCAL & \multicolumn{2}{|l|}{ MÃOS DOS MANIPULADORES } \\
\hline RESPONSABILIDADE & \multicolumn{2}{|l|}{ OPERACIONAL LINHA DE PROCESSO } \\
\hline E.P.I. & & \\
\hline $\begin{array}{l}\text { PRODUTOS } \\
\text { UTILIZADOS }\end{array}$ & \multicolumn{2}{|l|}{$\begin{array}{l}\text { SABONETE BACTERICIDA E } \\
\text { GEL SANITIZANTE }\end{array}$} \\
\hline CONCENTRAÇÃO & \multicolumn{2}{|l|}{ PRONTOS PARA USO } \\
\hline $\begin{array}{l}\text { PREPARO DA } \\
\text { SOLUÇÃO }\end{array}$ & \multicolumn{2}{|l|}{ PURO } \\
\hline TEMPERATURA & \multicolumn{2}{|l|}{ AMBIENTE } \\
\hline TEMPO & \multicolumn{2}{|l|}{ NÃO DETERMINADO } \\
\hline FREQUENCIA & \multicolumn{2}{|c|}{$\begin{array}{l}\text { AO ENTRAR NA ÁREA DE PRODUÇÃO E SEMPRE QUE } \\
\text { NECESSÁRIO }\end{array}$} \\
\hline \multicolumn{3}{|l|}{ PROCEDIMENTO } \\
\hline \multicolumn{3}{|c|}{$\begin{array}{l}\text { 1. Umedecer as mãos e antebraços com água a temperatura ambiente; } \\
\text { 2. Dosar duas porções de sabonete bactericida e esfregar as mãos e an } \\
\text { 3. Enxaguar com água em abundância até a retirada total do sabonete; } \\
\text { 4. Enxugar as mãos com toalha descartável; } \\
\text { 5. Aplicar duas porções de gel sanitizante nas mãos e antebraços } \\
\text { 6. Deixar secar naturalmente. }\end{array}$} \\
\hline ELABORADO POR & VERIFICADO POR & O POR \\
\hline
\end{tabular}




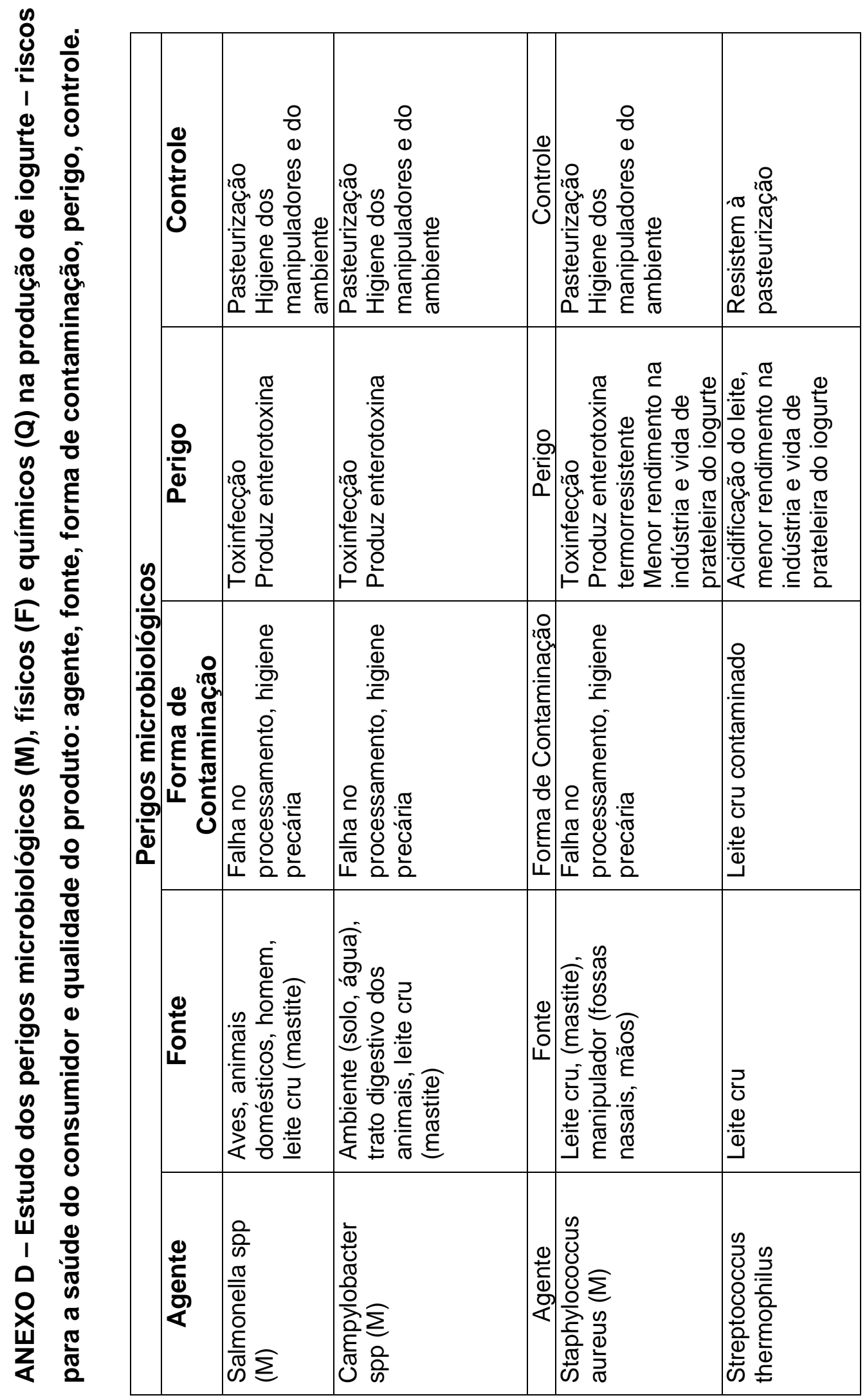




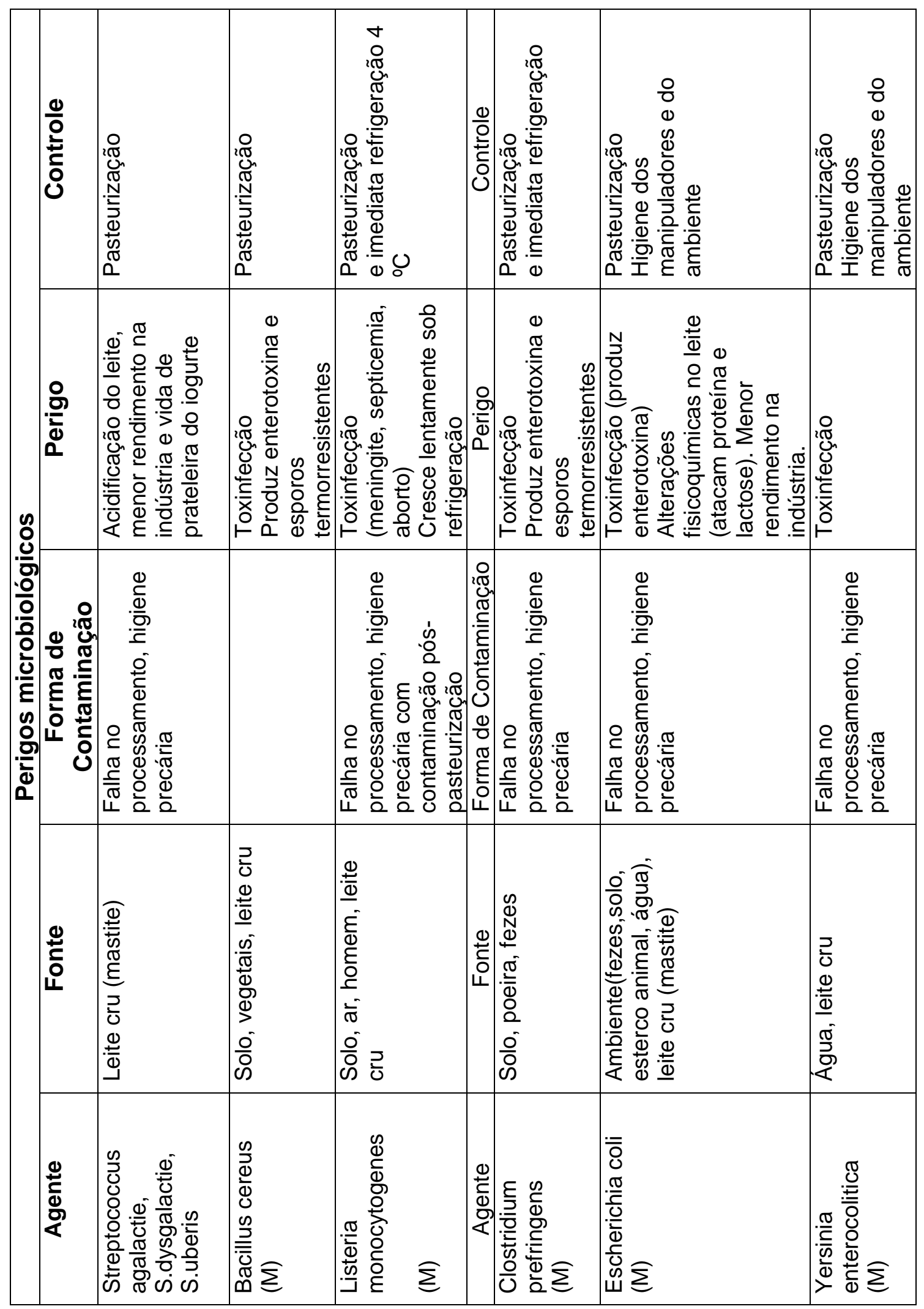




\begin{tabular}{|c|c|c|c|c|c|c|c|}
\hline & 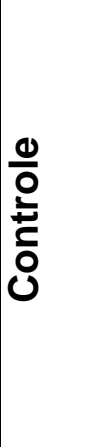 & 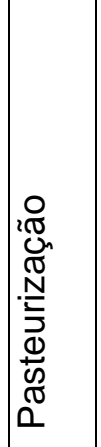 & 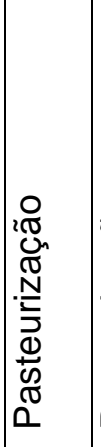 & 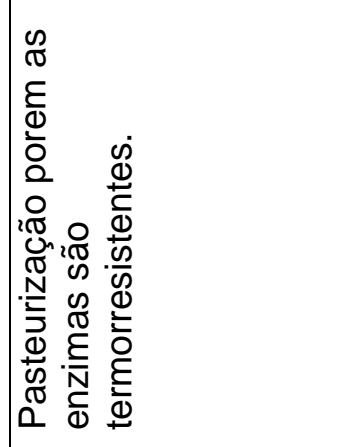 & 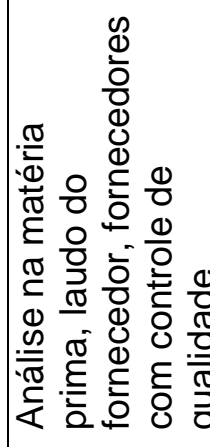 & 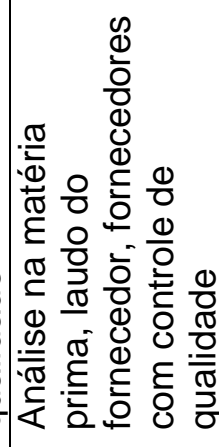 & 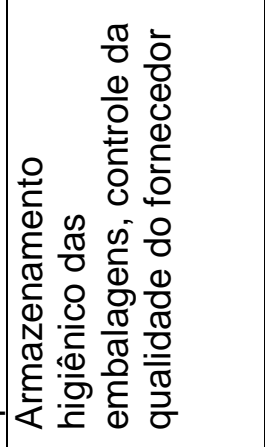 \\
\hline a & :음 & 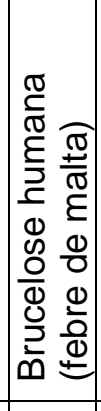 & 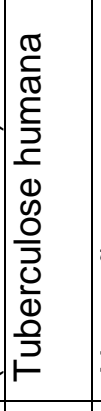 & 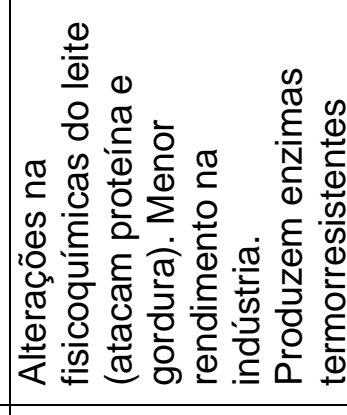 & 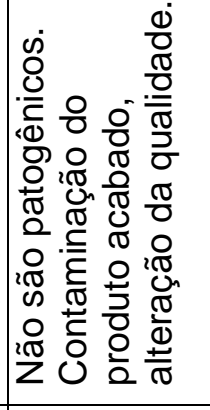 & 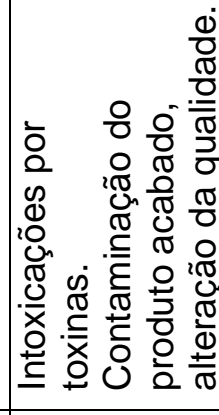 & 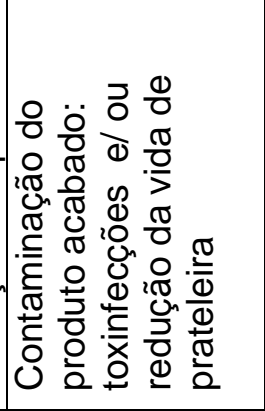 \\
\hline 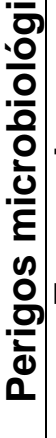 & 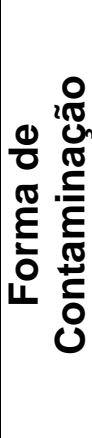 & 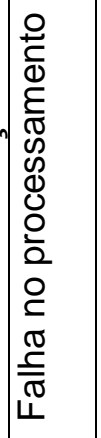 & 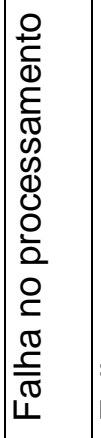 & 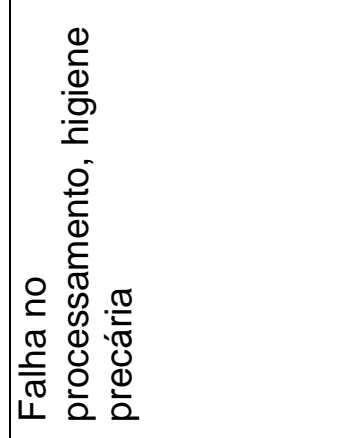 & 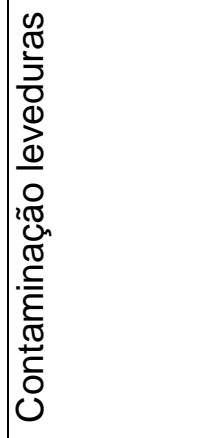 & 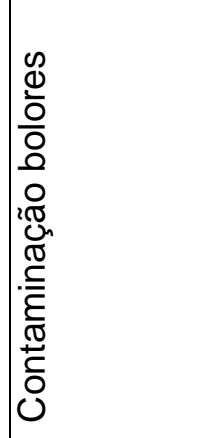 & 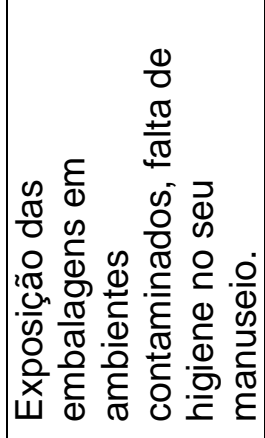 \\
\hline & 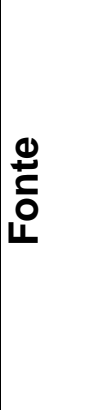 & 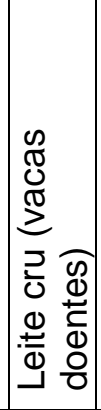 & 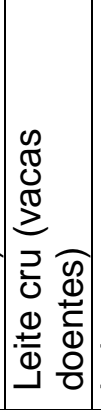 & & 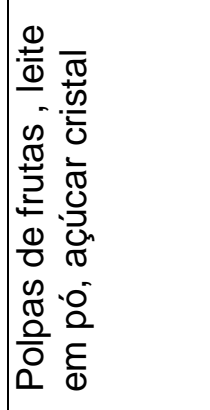 & 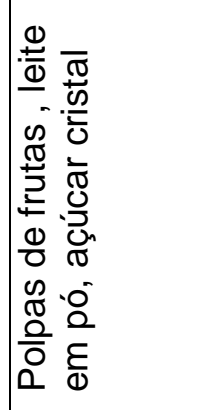 & 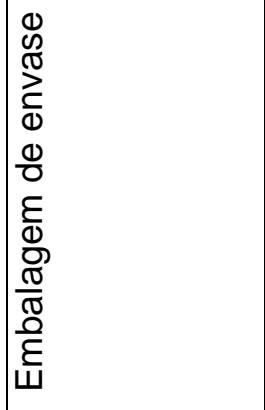 \\
\hline & 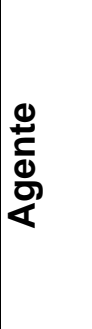 & 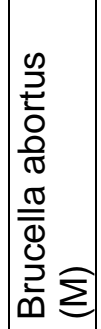 & 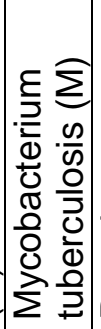 & 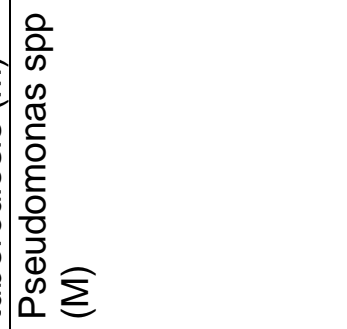 & 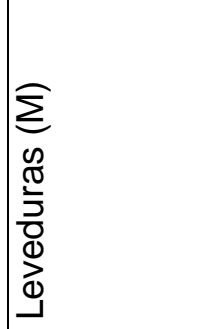 & 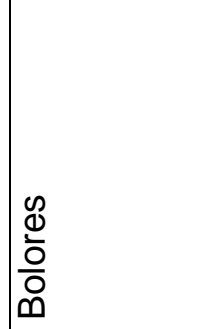 & 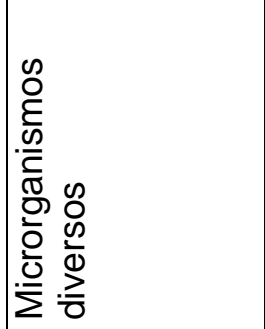 \\
\hline
\end{tabular}




\begin{tabular}{|c|c|c|c|c|c|}
\hline & 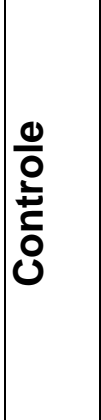 & 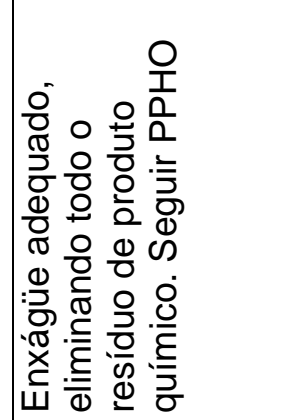 & 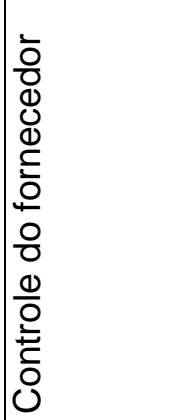 & 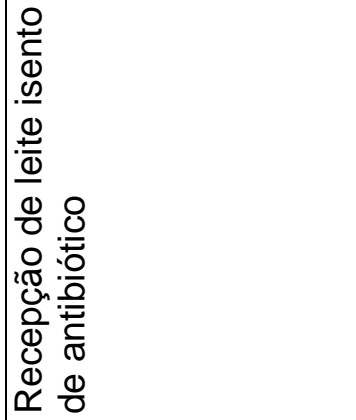 & 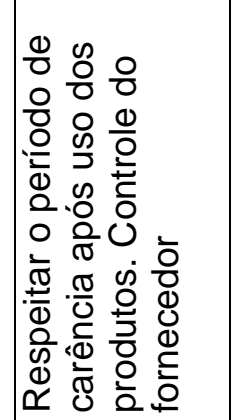 \\
\hline 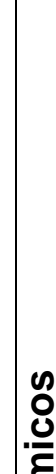 & 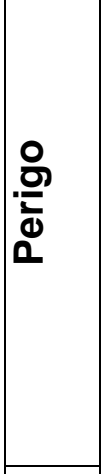 & 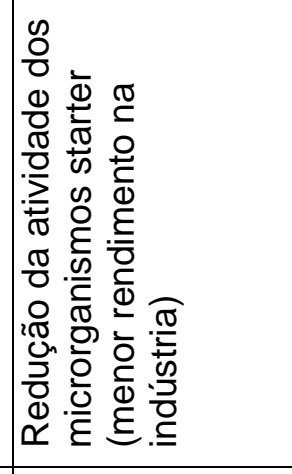 & 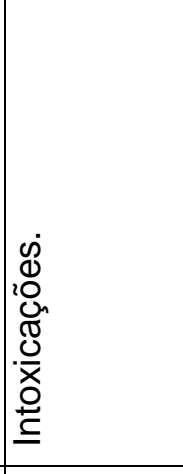 & 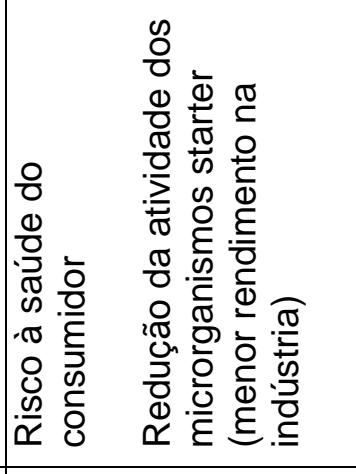 & 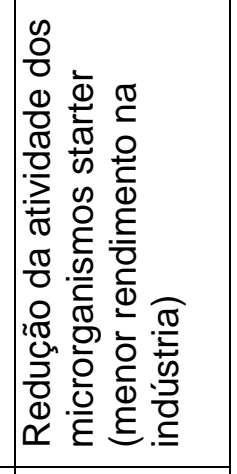 \\
\hline & 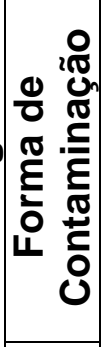 & 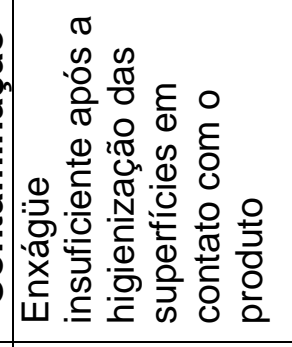 & 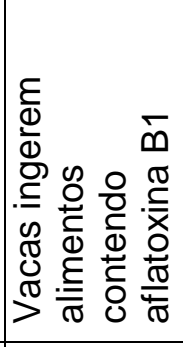 & 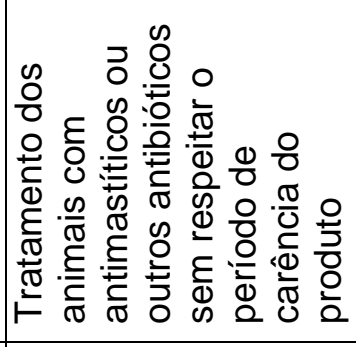 & 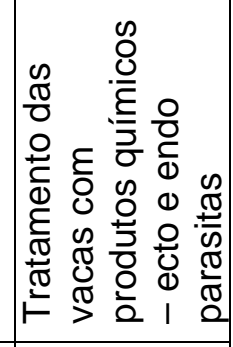 \\
\hline & 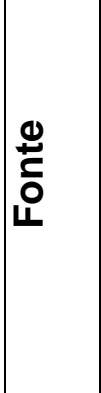 & 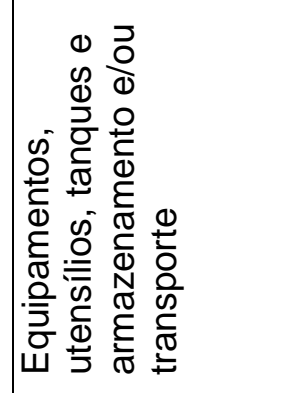 & |ঙ.ّ & 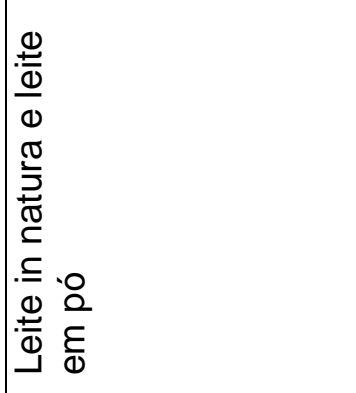 & 䓂 \\
\hline & 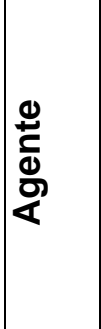 & 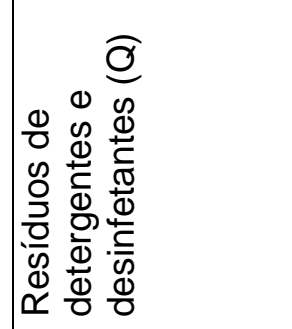 & 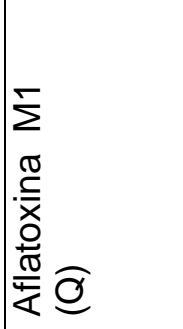 & 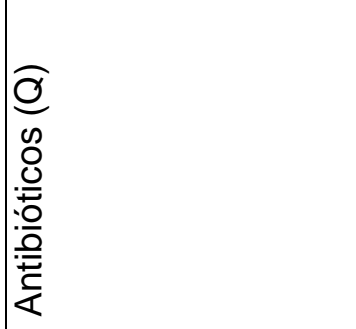 & 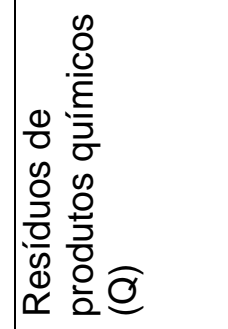 \\
\hline
\end{tabular}




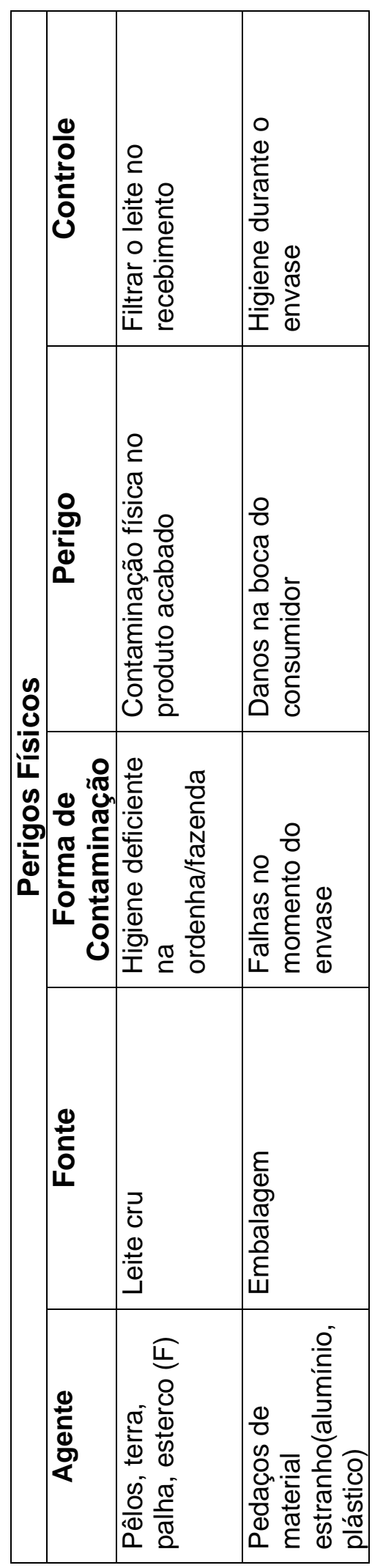


곤

\begin{tabular}{|c|c|c|}
\hline 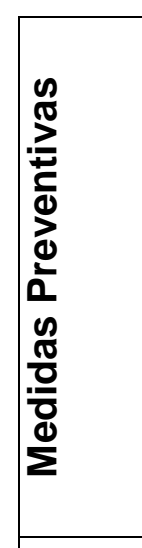 & 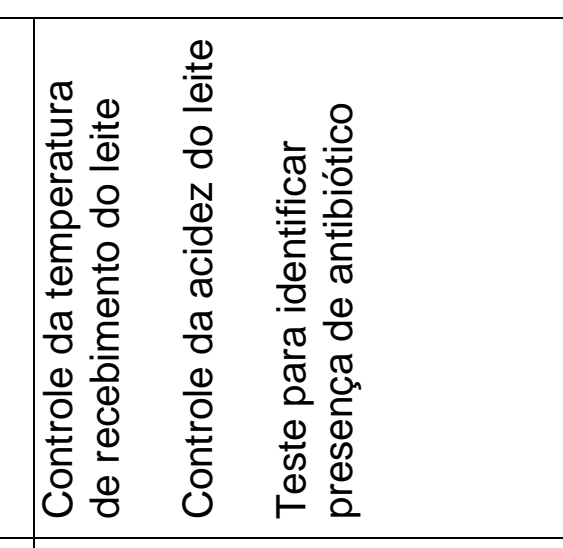 & 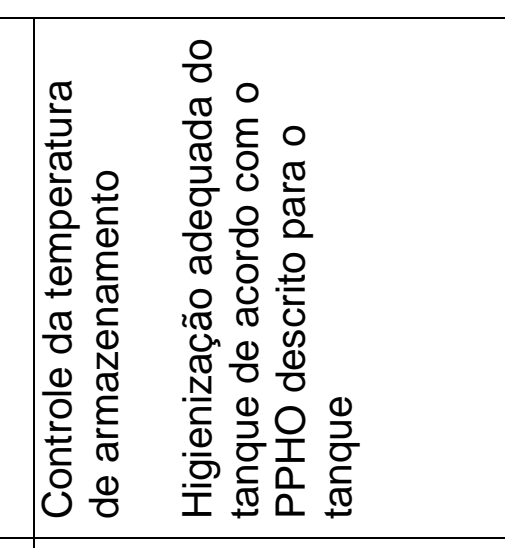 \\
\hline 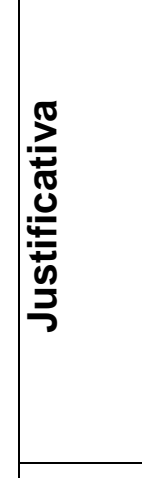 & 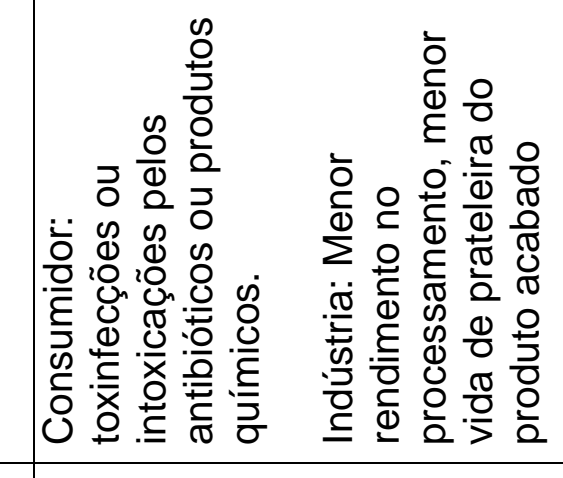 & 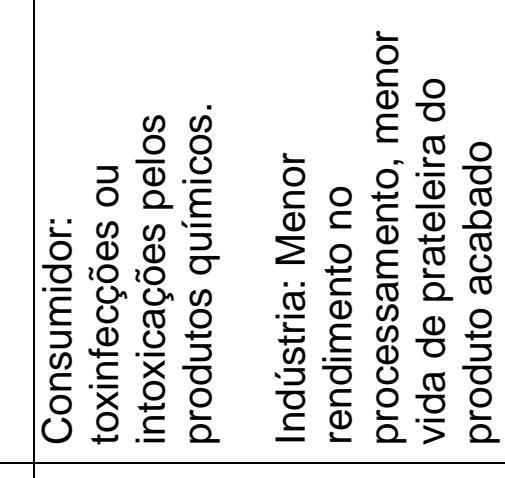 \\
\hline 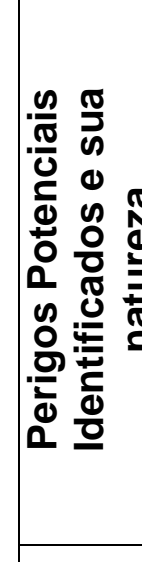 & 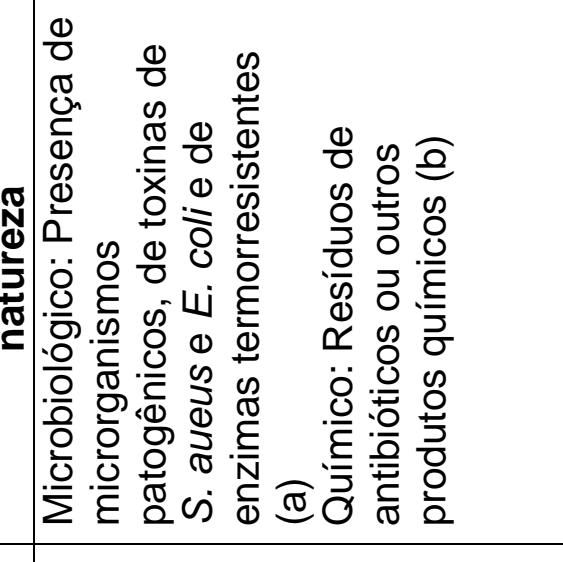 & 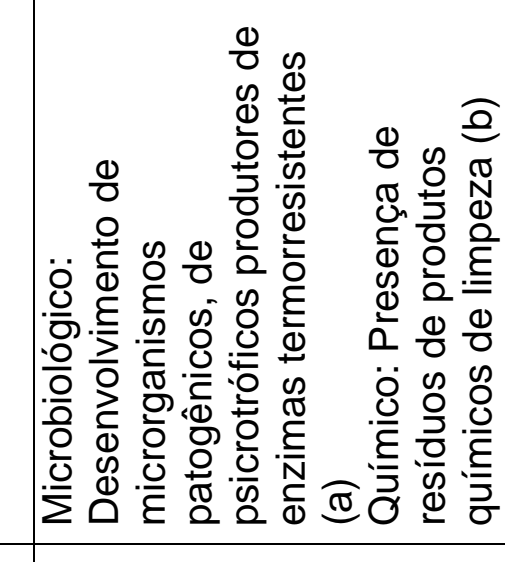 \\
\hline 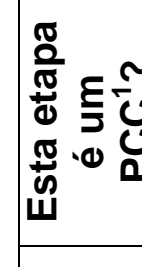 & 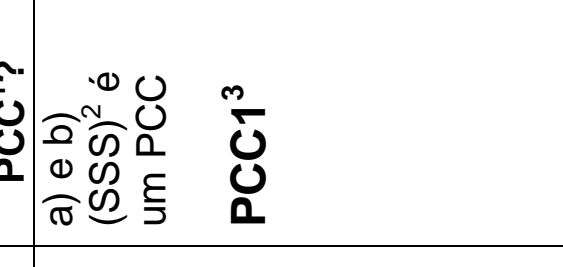 & 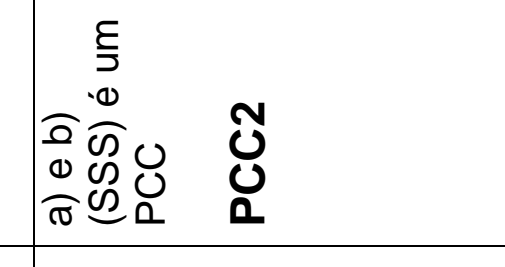 \\
\hline 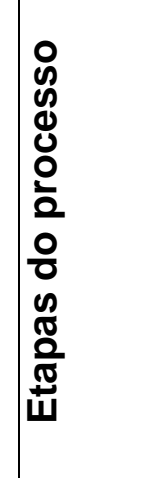 & 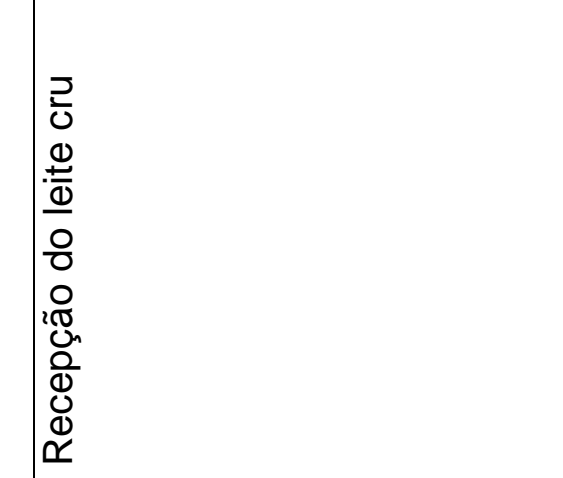 & 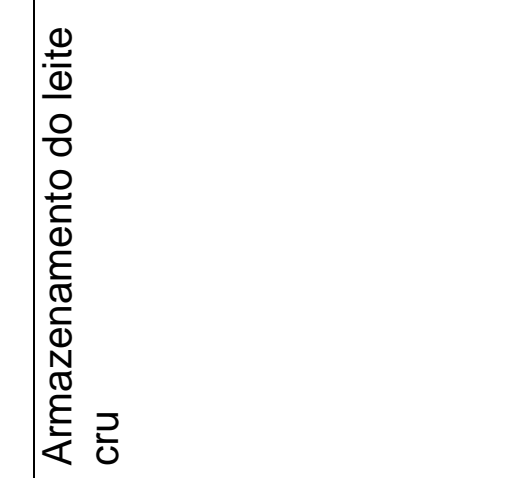 \\
\hline
\end{tabular}




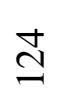

\begin{tabular}{|c|c|c|c|c|c|c|}
\hline 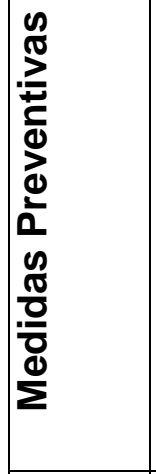 & 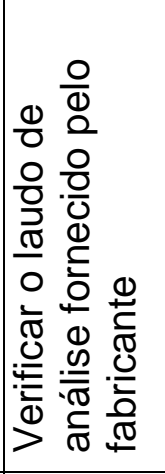 & 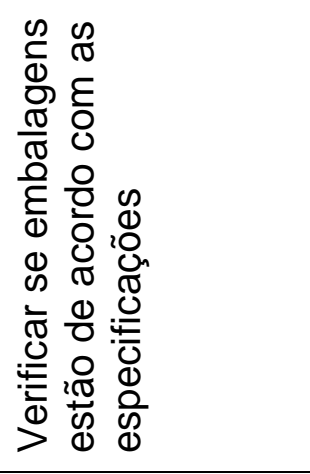 & & & & \\
\hline 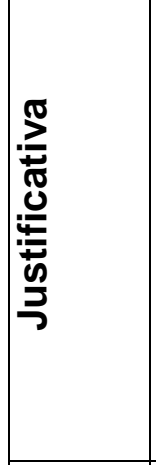 & 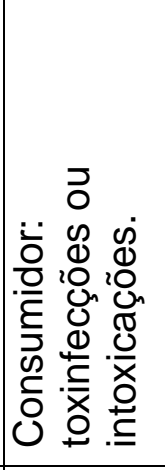 & 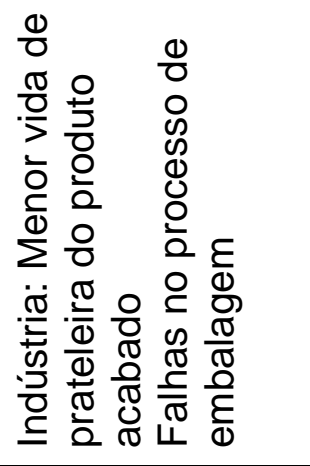 & & & & \\
\hline 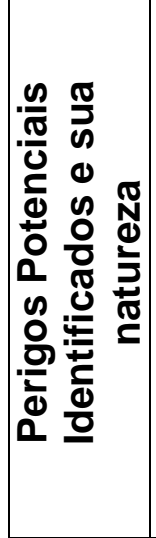 & 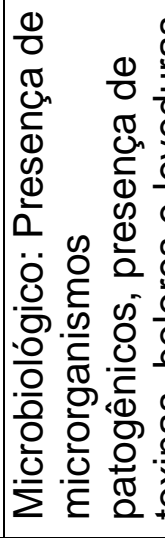 & 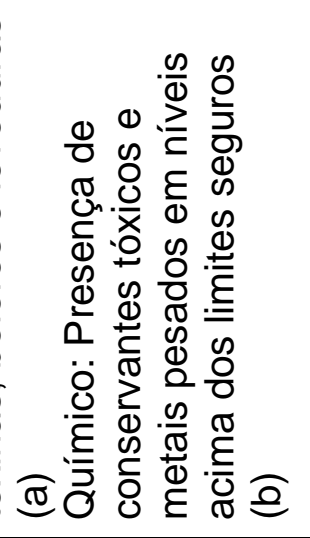 & 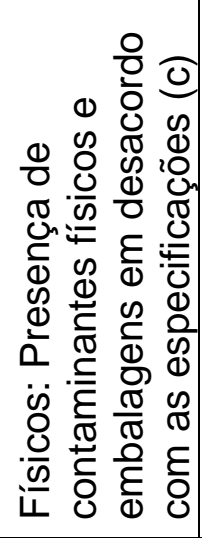 & & & \\
\hline 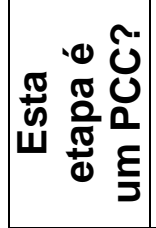 & 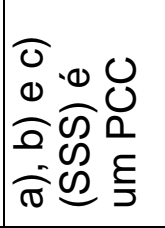 & 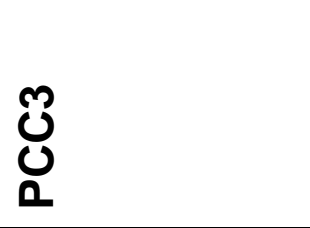 & & 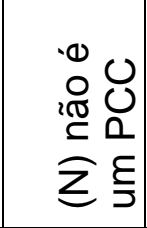 & 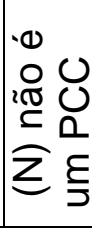 & 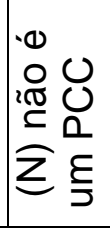 \\
\hline 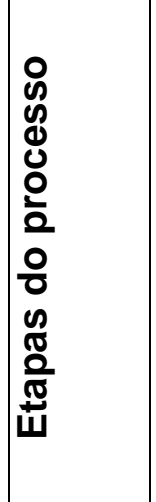 & 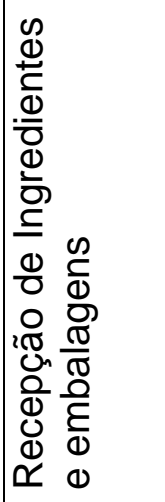 & & & 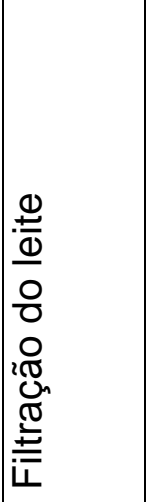 & 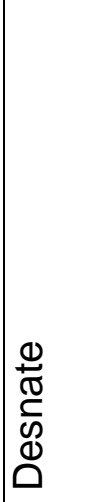 & 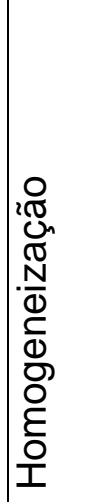 \\
\hline
\end{tabular}




\begin{tabular}{|c|c|c|c|}
\hline 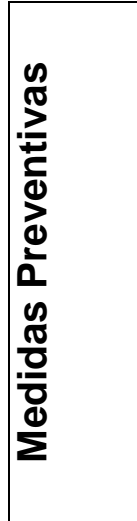 & 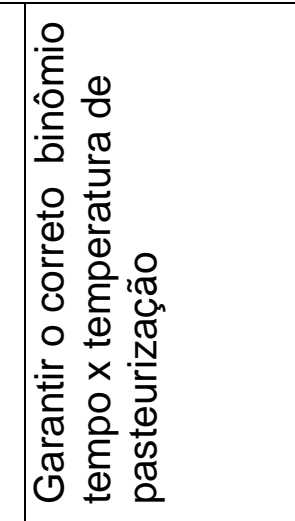 & 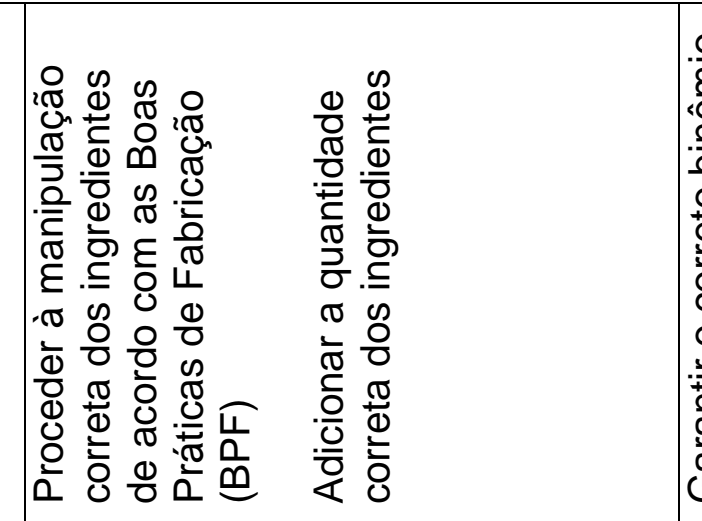 & 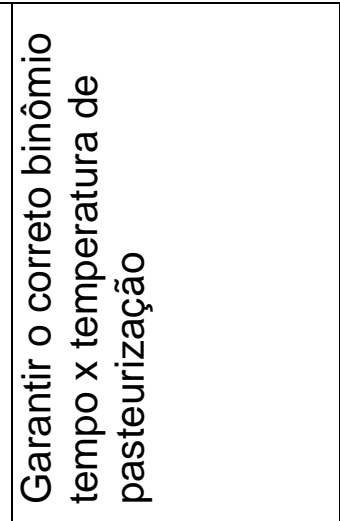 \\
\hline 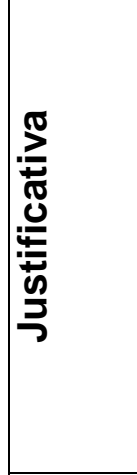 & 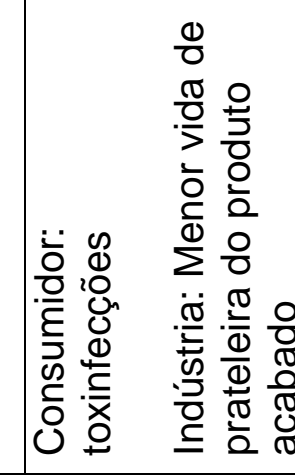 & 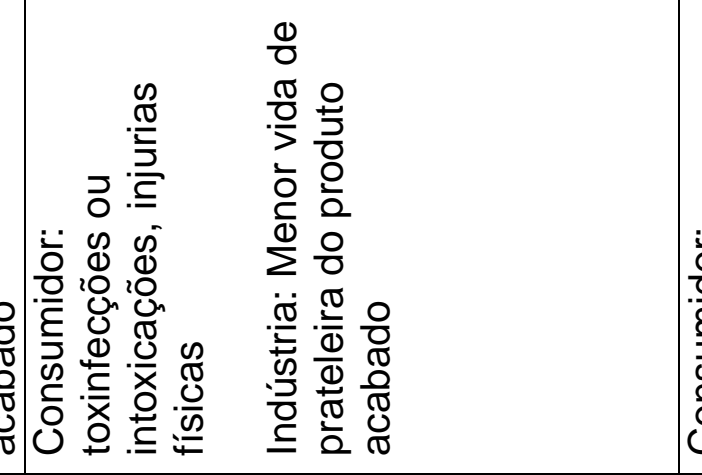 & 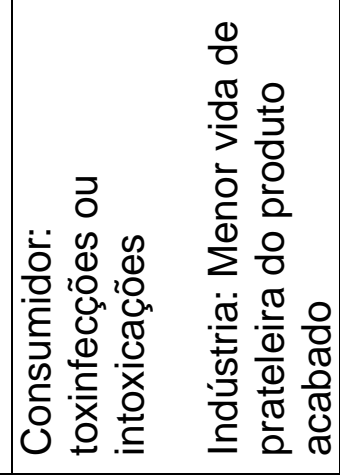 \\
\hline 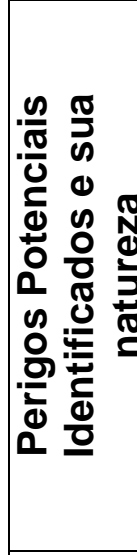 & 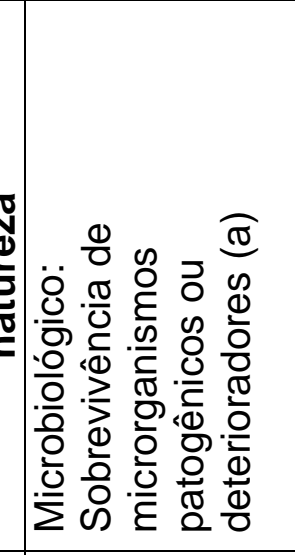 & 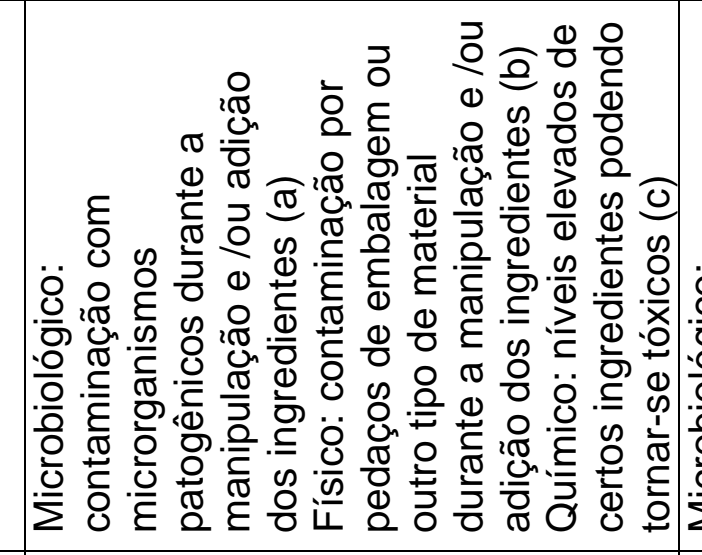 & 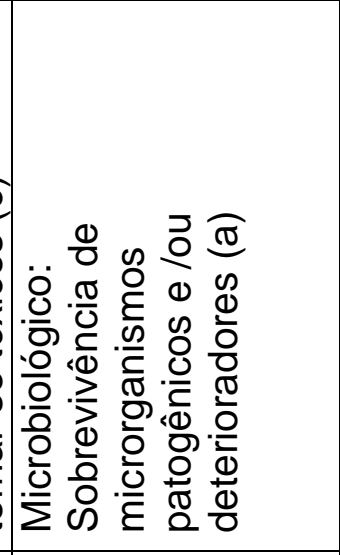 \\
\hline 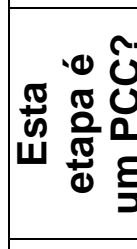 & 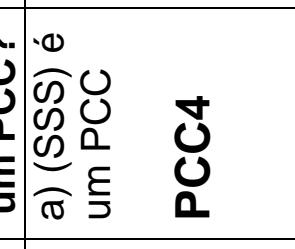 & 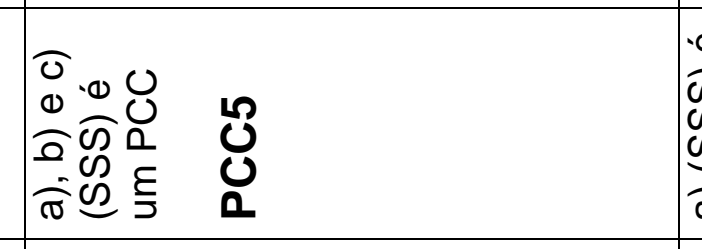 & 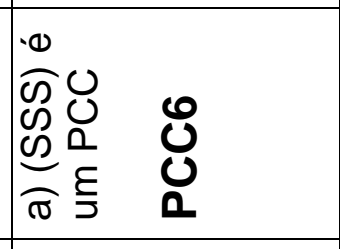 \\
\hline 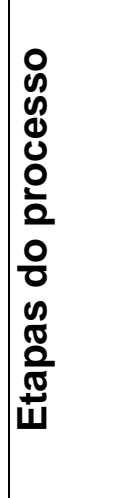 & 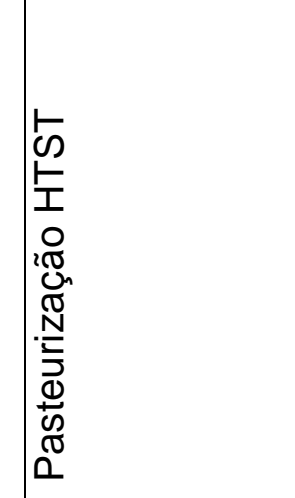 & 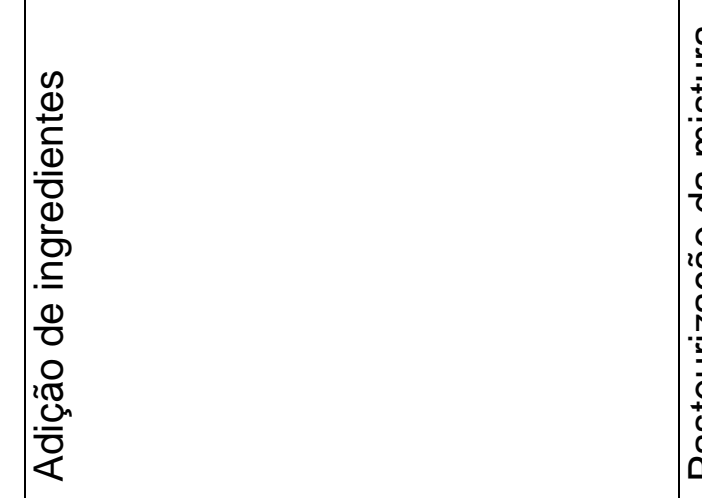 & 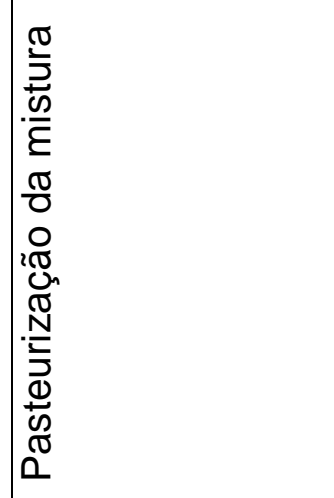 \\
\hline
\end{tabular}




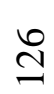

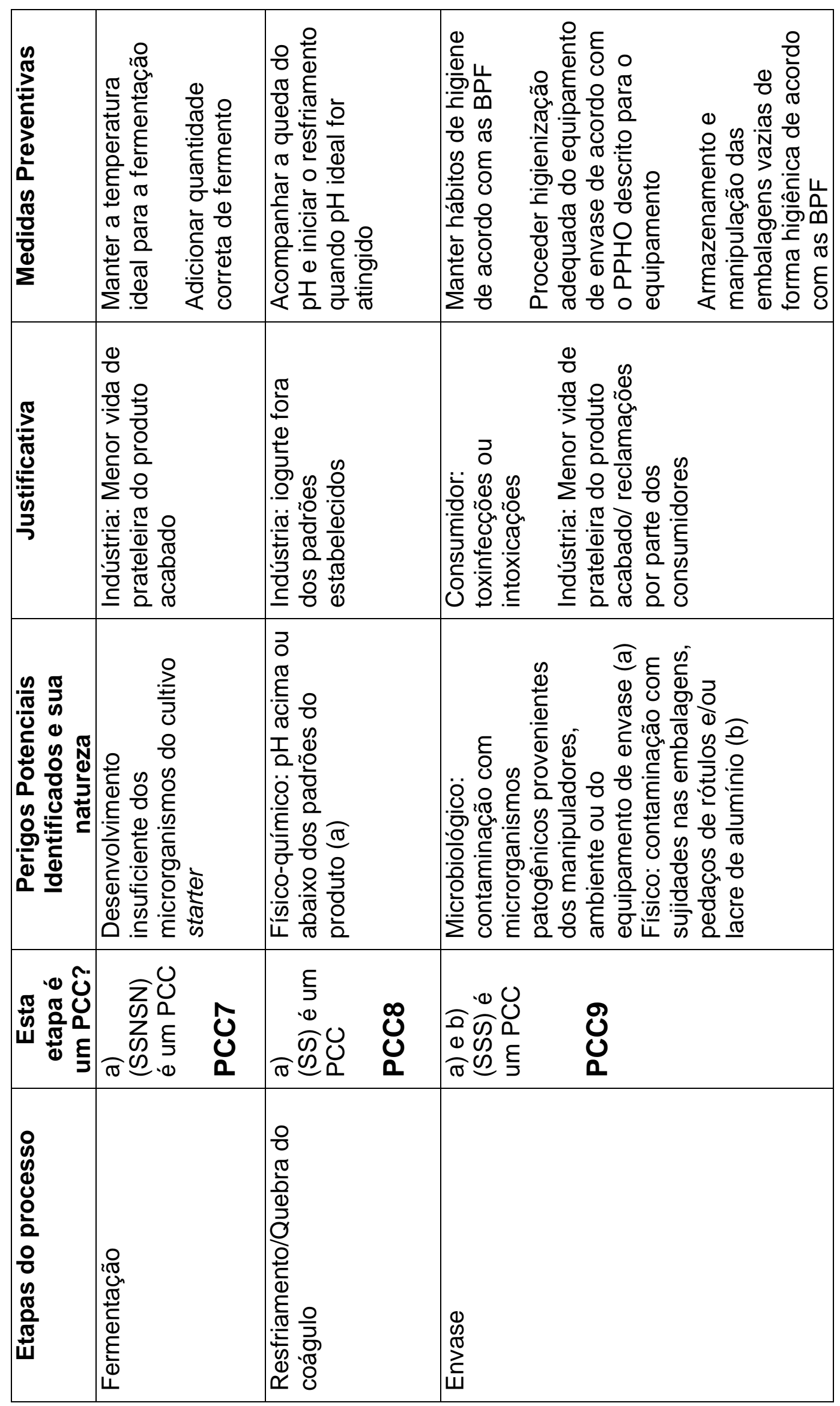


ป

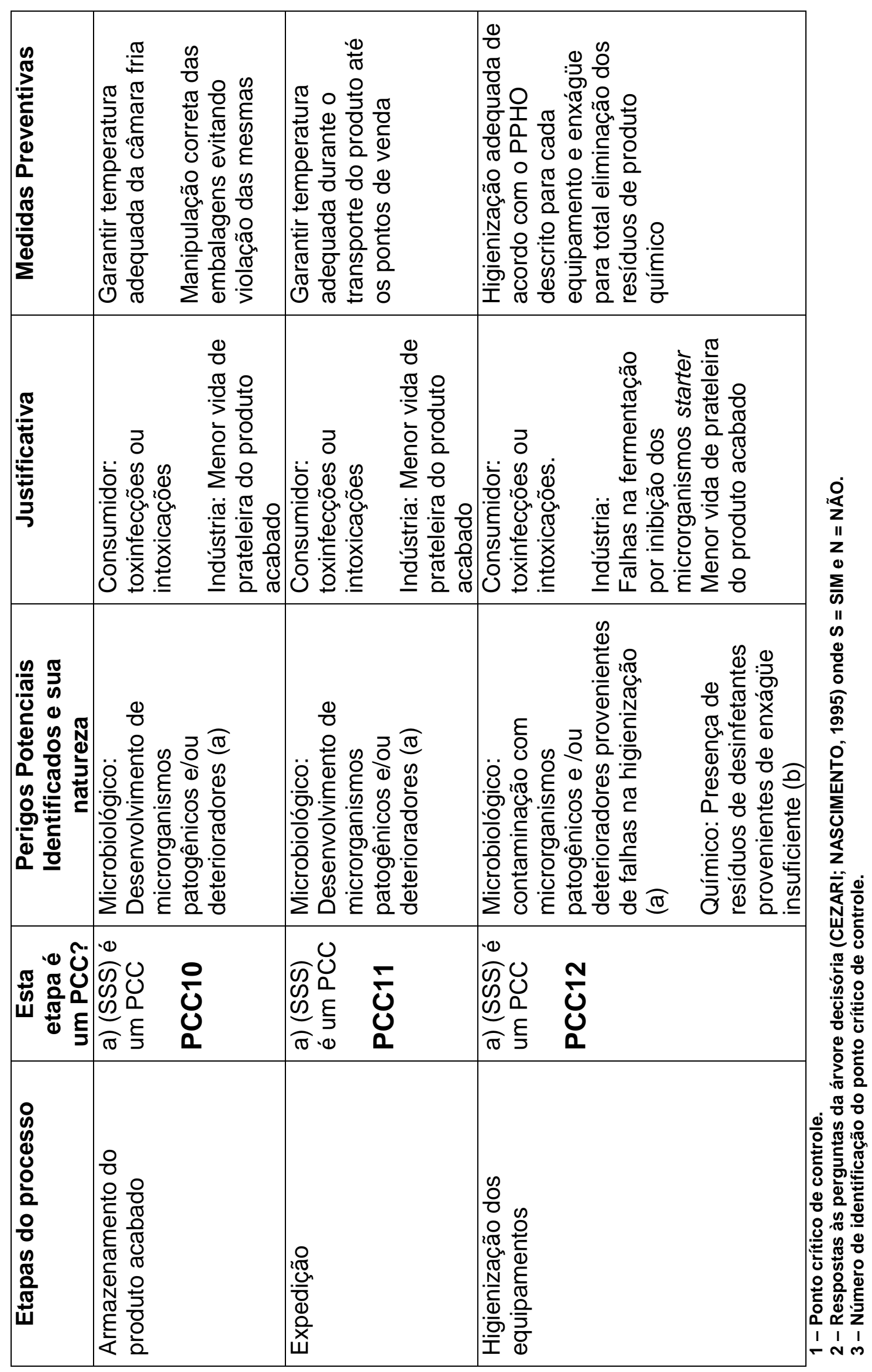


ANEXO F - Instruções de trabalho dos pontos críticos de controle (PCC) e respectivas planilhas de monitoramento

\begin{tabular}{|c|c|c|}
\hline \multirow{3}{*}{$\begin{array}{c}\text { Logo } \\
\text { da Empresa }\end{array}$} & \multirow{3}{*}{ INSTRUÇÃO DE TRABALHO } & Código: IT-004 \\
\hline & & Revisão: 0 \\
\hline & & Emissão: 08/11/06 \\
\hline OPERAÇÃO & \multicolumn{2}{|c|}{ RECEPÇÃO DE LEITE CRU - AMOSTRAGEM } \\
\hline $\begin{array}{l}\text { RESPONSABILIDADE } \\
\text { E.P.I. }\end{array}$ & \multicolumn{2}{|c|}{ LABORATÓRIO CONTROLE DE QUALIDADE } \\
\hline $\begin{array}{l}\text { RESPONSAVEL } \\
\text { PELAS ANÁLISES }\end{array}$ & \multicolumn{2}{|c|}{ LABORATÓRIO CONTROLE DE QUALIDADE } \\
\hline \multicolumn{3}{|c|}{$\begin{array}{l}\text { 1. Na chegada do caminhão tanque, obter com o motorista o boletim de } \\
\text { controle do leite preenchido na fazenda antes do carregamento; } \\
\text { 2. Agitar o leite do tanque utilizando o agitador de metal; } \\
\text { 3. Em um recipiente asséptico, coletar uma amostra do leite de cada } \\
\text { compartimento do tanque; } \\
\text { 4. Medir a temperatura imediatamente; } \\
\text { 5. Levar as amostras para o laboratório e realizar os testes para determinação } \\
\text { da acidez e da presença de antibiótico; } \\
\text { 6. Preencher a planilha de análise de leite cru com os resultados obtidos; } \\
\text { 7. Estando os resultados de acordo com os padrões mínimos estabelecidos, } \\
\text { liberar para descarga; } \\
\text { 8. Caso contrário, rejeitar o leite; } \\
\text { 9. Em seguida, realizar os seguintes testes complementares: } \\
\text { - Redutase } \\
\text { - Alcalinos } \\
\text { - Pus } \\
\text { - Sangue }\end{array}$} \\
\hline ELABORADO POR & VERIFICADO POR & APROVADO POR \\
\hline
\end{tabular}




\begin{tabular}{|c|c|}
\hline Logo & APPCC \\
da empresa & ANÁLISE DE PERIGOS E PONTOS CRÍTICOS \\
& DE CONTROLE \\
\hline
\end{tabular}

\section{REGISTRO DE MONITORAMENTO DE PCC \\ Freqüência: a cada caminhão que chega}

RECEPÇÃO DO LEITE CRU

\begin{tabular}{|c|c|c|c|c|c|c|}
\hline \multirow[t]{2}{*}{ Data } & \multirow[t]{2}{*}{ Fornecedor } & \multirow{2}{*}{\begin{tabular}{|l|} 
Temp. \\
$<5,0 \stackrel{\circ}{ } \mathrm{C}$
\end{tabular}} & \multirow{2}{*}{\begin{tabular}{|l|} 
Acidez \\
$16-18^{\circ} \mathrm{D}$
\end{tabular}} & \multirow{2}{*}{$\begin{array}{c}\text { Antibiótico } \\
\text { Ausente }\end{array}$} & \multirow[t]{2}{*}{ Ação Corretiva } & \multirow[t]{2}{*}{ Funcionário } \\
\hline & & & & & & \\
\hline & & & & & & \\
\hline & & & & & & \\
\hline & & & & & & \\
\hline & & & & & & \\
\hline & & & & & & \\
\hline & & & & & & \\
\hline & & & & & & \\
\hline & & & & & & \\
\hline & & & & & & \\
\hline & & & & & & \\
\hline & & & & & & \\
\hline & & & & & & \\
\hline & & & & & & \\
\hline & & & & & & \\
\hline & & & & & & \\
\hline
\end{tabular}

PROCEDIMENTO: de acordo com a IT 004 (Recepção de leite cru) AÇÃO CORRETIVA:

Temperatura: Se temperatura até $5,0^{\circ} \mathrm{C}$ e acidez dentro dos níveis aceitáveis, resfriar o leite até $4 \stackrel{\circ}{\circ}$ e descarregar.

Se temperatura acima de $5,0^{\circ} \mathrm{C}$, rejeitar o leite.

Acidez: Se acidez estiver acima de $18 \stackrel{\circ}{\circ}$, rejeitar o leite.

Antibiótico: Se houver presença de antibiótico, rejeitar o leite. 


\begin{tabular}{|c|c|}
\hline $\begin{array}{c}\text { Logo da } \\
\text { Empresa }\end{array}$ & APPCC \\
& ANÁLISE DE PERIGOS E PONTOS CRÍTICOS DE CONTROLE \\
\hline
\end{tabular}

\section{REGISTRO DE MONITORAMENTO DE PCC \\ Freqüência: a cada 2 horas}

ARMAZENAMENTO DE LEITE CRU

\begin{tabular}{|l|l|l|l|l|l|}
\hline Data & Hora & $\begin{array}{c}\text { Temp. } \\
\leq 4 \mathbf{4}^{\circ}\end{array}$ & $\begin{array}{c}\text { Acidez } \\
\text { 16-18 } \mathbf{D}\end{array}$ & Ação Corretiva & Funcionário \\
\hline & & & & & \\
\hline & & & & & \\
\hline & & & & & \\
\hline & & & & & \\
\hline & & & & & \\
\hline & & & & & \\
\hline & & & & & \\
\hline & & & & & \\
\hline & & & & & \\
\hline & & & & & \\
\hline & & & & & \\
\hline & & & & & \\
\hline
\end{tabular}

PROCEDIMENTO: Medir a temperatura e analisar acidez do leite a cada 2 horas.

AÇÃO CORRETIVA: Caso a temperatura esteja acima de $4{ }^{\circ} \mathrm{C}$ resfriar o leite descartar o leite

Caso a acidez esteja acima de $18^{\circ} \mathrm{D}$, comunicar ao gerente e 


\begin{tabular}{|c|c|c|c|}
\hline \multirow{2}{*}{$\begin{array}{c}\text { Logo } \\
\text { da Empresa }\end{array}$} & \multirow{2}{*}{\multicolumn{2}{|c|}{ INSTRUÇÃO DE TRABALHO }} & \begin{tabular}{|l} 
Código: IT-010 \\
Revisão: 0
\end{tabular} \\
\hline & & & $\begin{array}{l}\text { Emissão: } \\
\text { 13/02/07 }\end{array}$ \\
\hline OPERAÇÃO & \multicolumn{3}{|c|}{ RECEBIMENTO EMBALAGENS } \\
\hline RESPONSABILIDADE & \multicolumn{3}{|c|}{ CONTROLE DE QUALIDADE } \\
\hline FREQUENCIA & \multicolumn{3}{|c|}{ A CADA LOTE RECEBIDO } \\
\hline \multicolumn{4}{|c|}{$\begin{array}{l}\text { 1. Antes da descarga do material, verificar as condições de acondicionamento } \\
\text { dos fardos no caminhão. Devem estar empilhados de forma organizada } \\
\text { evitando danos às embalagens; } \\
\text { 2. Conferir se a quantidade recebida é a mesma constante na nota fiscal que } \\
\text { acompanha a carga; } \\
\text { 3. De acordo com o plano de amostragem, coletar uma a mostra do material } \\
\text { para análise física; } \\
\text { 4. Proceder à análise das amostras utilizando a planilha de Controle de } \\
\text { Recebimento de Embalagens; } \\
\text { 5. Estando o material de acordo com os padrões, autorizar a descarga; } \\
\text { 6. A descarga deve ser realizada de forma cuidadosa para evitar que as } \\
\text { embalagens amassem ou que os fardos se abram; } \\
\text { 7. Acondicionar os fardos no almoxarifado, deixando os mais velhos na frente } \\
\text { para serem utilizados primeiro; } \\
\text { 8. Os lotes cujos problemas de não conformidades surgirem durante o uso } \\
\text { devem ser separados e identificados para devolução ao fornecedor. } \\
\text { 9. Entrar em contato com o fornecedor formalizando a devolução caso algum } \\
\text { lote seja rejeitado }\end{array}$} \\
\hline ELABORADO POR & VERIFICADO POR & APF & POR \\
\hline
\end{tabular}




\begin{tabular}{|c|c|}
\hline Logo da & APPCC \\
Empresa & ANÁLISE DE PERIGOS E PONTOS CRÍTICOS DE \\
& CONTROLE \\
\hline
\end{tabular}

\section{REGISTRO DE MONITORAMENTO DE PCC Freqüência: a cada lote que chega}

\section{CONTROLE RECEBIMENTO EMBALAGENS}

Data Entrada

Tipo de Embalagem

Quantidade recebida Lote

Fabricante No.Laudo do Fabricante

\begin{tabular}{|c|c|c|c|c|}
\hline Determinação & Padrão & \multicolumn{2}{|c|}{ Análise } & Obs \\
\hline Plano de Amostragem & $1 \%$ dos fardos recebidos & & & \\
\hline Aspecto externo fardos & Lacrados, sem aberturas & A & $\mathrm{R}$ & \\
\hline Etiqueta de Identificação & No. Lote e data de fabricação & A & $\mathrm{R}$ & \\
\hline \multicolumn{5}{|c|}{ Garrafas } \\
\hline No. de garrafas / fardo & De acordo c/ etiqueta lote & A & $\mathrm{R}$ & \\
\hline Aspecto geral garrafas & $\begin{array}{c}\text { Íntegras, sem partes } \\
\text { amassadas }\end{array}$ & A & $\mathrm{R}$ & \\
\hline Higiene interna garrafas & Limpa, sem material estranho & A & $\mathrm{R}$ & \\
\hline Peso cada garrafa $(\mathrm{g})$ & $36-40$ para $1000 \mathrm{ml}$ & A & $\mathrm{R}$ & \\
\hline Peso cada garrafa $(\mathrm{g})$ & $9,5-11,5$ para $180 \mathrm{ml}$ & A & $\mathrm{R}$ & \\
\hline Presença de rebarbas & Max. 2\% & A & $\mathrm{R}$ & \\
\hline Translucidez & Comparar com garrafa padrão & A & $\mathrm{R}$ & \\
\hline Estabilidade da base & Min. 98\% & A & $\mathrm{R}$ & \\
\hline Volume útil (1000ml) & $1040-1080 \mathrm{ml}$ & A & $\mathrm{R}$ & \\
\hline Volume útil $(180 \mathrm{ml})$ & $180-200 \mathrm{ml}$ & A & $\mathrm{R}$ & \\
\hline Cor & Comparar com garrafa padrão & $\mathrm{A}$ & $\mathrm{R}$ & \\
\hline \multicolumn{5}{|c|}{ Tampas } \\
\hline Peso dos fardos $(\mathrm{Kg})$ & De acordo com etiqueta lote & A & $\mathrm{R}$ & \\
\hline Peso da tampa (g) & & A & $\mathrm{R}$ & \\
\hline $\begin{array}{l}\text { Diâmetro interno rosca } \\
\text { (mm) }\end{array}$ & & $A$ & $\mathrm{R}$ & \\
\hline $\begin{array}{l}\text { Diâmetro externo } \\
\text { rosca }(\mathrm{mm})\end{array}$ & & $A$ & $\mathrm{R}$ & \\
\hline Altura da rosca $(\mathrm{mm})$ & & $\mathrm{A}$ & $\mathrm{R}$ & \\
\hline Cor & & $A$ & $\mathrm{R}$ & \\
\hline $\begin{array}{l}\text { Aspecto visual do } \\
\text { alumínio }\end{array}$ & $\begin{array}{c}\text { Íntegro, sem presença de } \\
\text { cortes }\end{array}$ & $A$ & $\mathrm{R}$ & \\
\hline
\end{tabular}

Análise - Aprovado: $\mathrm{A}$ Reprovado: $\mathrm{R}$

Analista 


\begin{tabular}{|c|c|c|c|}
\hline \multirow{2}{*}{$\begin{array}{c}\text { Logo } \\
\text { da Empresa }\end{array}$} & \multirow{2}{*}{\multicolumn{2}{|c|}{ INSTRUÇÃO DE TRABALHO }} & $\begin{array}{l}\text { Código: IT-011 } \\
\text { Revisão: } 0\end{array}$ \\
\hline & & & Emissão: 13/02/07 \\
\hline OPERAÇÃO & \multicolumn{3}{|c|}{ AUDITORIAS A FORNECEDORES } \\
\hline RESPONSABILIDADE & \multicolumn{3}{|c|}{ CONTROLE DE QUALIDADE } \\
\hline FREQUENCIA & \multicolumn{3}{|c|}{ A CADA 6 MESES, OU ANTES, SE NECESSARIO } \\
\hline \multicolumn{4}{|l|}{ PROCEDIMENTO } \\
\hline \multicolumn{4}{|c|}{$\begin{array}{l}\text { 1. As visitas aos fornecedores devem ser realizadas periodicamente e sem } \\
\text { comunicação prévia aos mesmos; } \\
\text { 2. Durante a visita, aplicar o check list específico a cada fornecedor; } \\
\text { 3. Após a visita, enviar ao fornecedor um relatório com as não conformidades } \\
\text { encontradas. O mesmo deve ser devolvido preenchido com as ações } \\
\text { corretivas previstas e um cronograma para sua realização; } \\
\text { 4. A ausência de correção das não conformidades pode levar ao cancelamento } \\
\text { das compras com o fornecedor. }\end{array}$} \\
\hline ELABORADO POR & VERIFICADO POR & APR & O POR \\
\hline
\end{tabular}




\section{Check-list para Avaliação das Condições de Higiene na Ordenha e Armazenamento de Leite Cru nos Fornecedores de Leite Freqüência: a cada 6 meses}

Fornecedor

Data:
Responsável

\begin{tabular}{|l|l|l|l|}
\hline Animais & Sim & Não & Ação corretiva \\
\hline $\begin{array}{l}\text { 1- A propriedade possui um médico veterinário responsável } \\
\text { pela saúde do rebanho? }\end{array}$ & & & \\
\hline $\begin{array}{l}\text { 2- Os animais são vacinados conta as principais doenças } \\
\text { que afetam o rebanho leiteiro? Ex. febre aftosa, brucelose }\end{array}$ & & & \\
\hline $\begin{array}{l}\text { 3- No intervalo entre as ordenha os animais permanecem } \\
\text { em local limpo e confortável (com sombra, água e alimento } \\
\text { a disposição)? }\end{array}$ & & & \\
\hline Na ordenha & Sim & Não & Ação corretiva \\
\hline $\begin{array}{l}\text { 4- Os ordenhadores têm hábitos higiênicos durante a } \\
\text { ordenha? Ex. lavar as mãos sempre que necessário, não } \\
\text { fumar, usar uniformes limpos. }\end{array}$ & & & \\
\hline $\begin{array}{l}\text { 4- É utilizado algum método para identificação de casos de } \\
\text { mastite durante a ordenha? Ex. teste de caneca, retirara } \\
\text { dos primeiros jatos. }\end{array}$ & & & \\
\hline $\begin{array}{l}\text { 5- É realizada higienização adequada dos tetos antes da } \\
\text { colocação do equipamento de ordenha? }\end{array}$ & & & \\
\hline $\begin{array}{l}\text { 6- Os animais com mastite são ordenhados } \\
\text { separadamente e seu leite é descartado? }\end{array}$ & & & \\
\hline $\begin{array}{l}\text { 7- É respeitado o período de carência do antibiótico para } \\
\text { utilização do leite dos animeis em tratamento contra } \\
\text { mastite? }\end{array}$ & & & \\
\hline 8- O leite é filtrado antes de ser armazenado no tanque? & & & \\
\hline $\begin{array}{l}\text { 9- Durante o armazenamento o leite é mantido sob } \\
\text { refrigeração a temperatura de no máximo 5 óC? }\end{array}$ & & & \\
\hline $\begin{array}{l}\text { 10- Os equipamentos de refrigeração estão em perfeito } \\
\text { estado de funcionamento? }\end{array}$ & & & \\
\hline Higienização & Sim & Não & Ação corretiva \\
\hline $\begin{array}{l}\text { 10- Os produtos utilizados para higienização dos } \\
\text { equipamentos são próprios para essa finalidade? }\end{array}$ & & & \\
\hline $\begin{array}{l}\text { 11- Há disponibilidade de água, detergente e sanitizantes } \\
\text { em quantidade suficiente? }\end{array}$ & & & \\
\hline $\begin{array}{l}\text { 12- O equipamento de ordenha é higienizado } \\
\text { adequadamente, respeitando-se concentração de } \\
\text { detergente, temperatura da água, tempo de circulação e } \\
\text { enxágüe? }\end{array}$ & & & \\
\hline $\begin{array}{l}\text { 13- O tanque de armazenamento é limpo adequadamente } \\
\text { após seu esvaziamento? }\end{array}$ & & & \\
\hline
\end{tabular}

Responsável pelo local 


\section{Check-list para Avaliação das Condições de Higiene Pessoal e das Instalações nos Fornecedores de Embalagens Freqüência: a cada 6 meses}

Fornecedor

Data:

1

Responsável

\begin{tabular}{|l|l|l|l|}
\hline Higiene Pessoal & Sim & Não & Ação corretiva \\
\hline 1- Os funcionários utilizam uniformes (jaleco, touca, luvas) & & & \\
\hline $\begin{array}{l}\text { 2- Os uniformes estão limpos e em bom estado de } \\
\text { conservação? }\end{array}$ & & & \\
\hline 3- Os manipuladores estão devidamente barbeados & & & \\
\hline 4- Os manipuladores estão com os cabelos cortados? & & & \\
\hline $\begin{array}{l}\text { 5- Os manipuladores sempre praticam atitudes higiênicas } \\
\text { como: não tossir ou espirrar sobre as embalagens, não } \\
\text { levar a mão à boca, nariz e orelhas, não cuspir no } \\
\text { ambiente, etc, evitando contaminação? }\end{array}$ & & & \\
\hline $\begin{array}{l}\text { 6- O manipuladores com curativos nas mãos e braços são } \\
\text { deslocados para serviços que não entrem em contato com } \\
\text { os alimentos? }\end{array}$ & & & \\
\hline $\begin{array}{l}\text { 7- Os manipuladores obedecem às recomendações de } \\
\text { fumar somente nas áreas destinadas a este fim? }\end{array}$ & & & \\
\hline Instalações & Sim & Não & Ação corretiva \\
\hline $\begin{array}{l}\text { 10- As instalações para a fabricação das embalagens são } \\
\text { limpas, sem acúmulo de lixo no chão? }\end{array}$ & & \\
\hline $\begin{array}{l}\text { 11- Existe controle de pragas nas instalações e área } \\
\text { externa? }\end{array}$ & & & \\
\hline $\begin{array}{l}\text { 11- O almoxarifado para produto acabado é limpo e } \\
\text { organizado? }\end{array}$ & & & \\
\hline $\begin{array}{l}\text { 12- Existe algum tipo de controle de qualidade durante a } \\
\text { produção? }\end{array}$ & & & \\
\hline 13- O controle de qualidade é documentado? & & \\
\hline $\begin{array}{l}\text { 14- Existe algum sistema que permita rastreabilidade, } \\
\text { recall ou retirada de produtos ou matérias-primas do } \\
\text { mercado, caso necessário? }\end{array}$ & & & \\
\hline
\end{tabular}

Responsável pelo local 


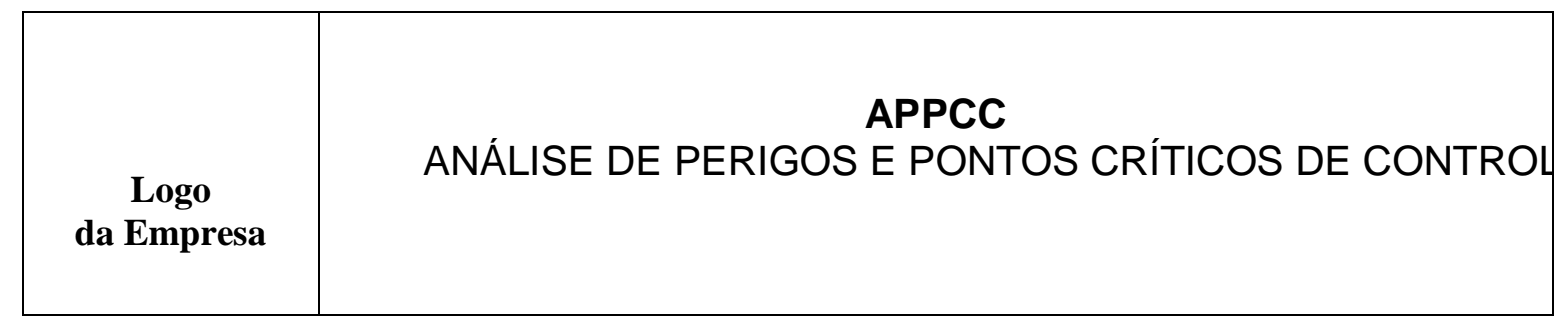

REGISTRO DE MONITORAMENTO DE PCC

Freqüência: a cada não conformidade

\begin{tabular}{|c|c|c|c|c|c|}
\hline \multicolumn{5}{|c|}{$\begin{array}{l}\text { OCORRÊNCIAS DE NÃO CONFORMIDADES COM } \\
\text { FORNECEDORES }\end{array}$} & ês/Ano: \\
\hline DIA & FORNECEDOR & PRODUTO & OCORRÊNCIA & $\begin{array}{c}\text { AÇÃO } \\
\text { CORRETIVA }\end{array}$ & FUNCIONÁRIO \\
\hline & & & & & \\
\hline & & & & & \\
\hline & & & & & \\
\hline & & & & & \\
\hline & & & & & \\
\hline & & & & & \\
\hline & & & & & \\
\hline & & & & & \\
\hline & & & & & \\
\hline & & & & & \\
\hline & & & & & \\
\hline
\end{tabular}




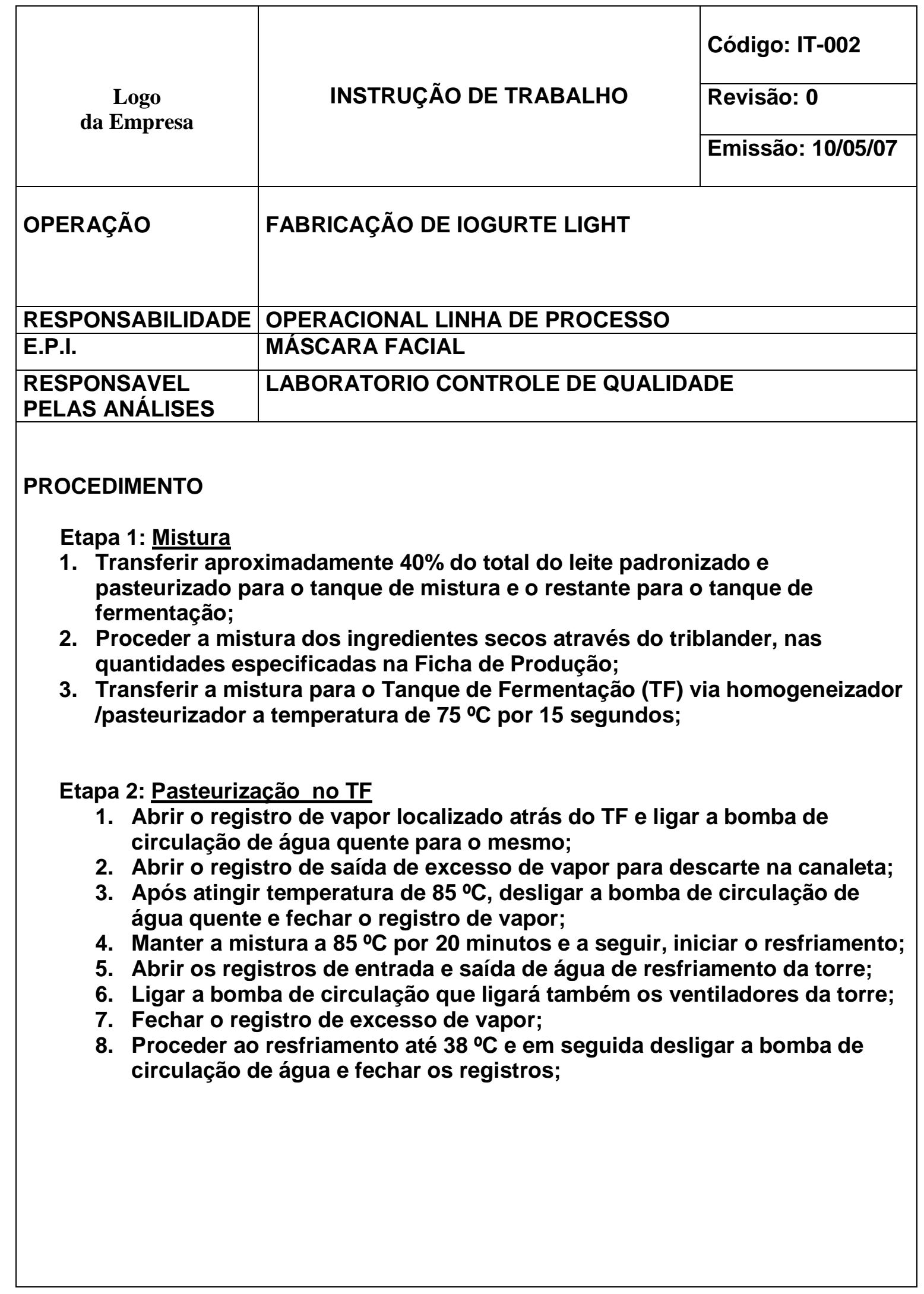




\section{Etapa 3: Fermentacão}

1. A temperatura de $38{ }^{\circ} \mathrm{C}$ e sob agitação rápida, adicionar manualmente 0 fermento através da abertura superior do TF;

2. Continuar a agitação por mais 5 minutos;

3. Desligar o agitador e deixar o produto descansar (fermentar) por aproximadamente 5 horas;

4. Obs: a temperatura deve ser mantida a $38^{\circ} \mathrm{C}$ durante toda a etapa de fermentação;

Etapa 4: Quebra da massa

1. Após o período de fermentação, coletar amostra do produto para análise do $\mathrm{pH}$;

2. Estando o pH entre 4,4-4,6, iniciar o resfriamento da massa, sob agitação lenta;

3. Abrir os registros de entrada e saída de água gelada e deixar resfriando até o envase.

Etapa 5: Adição de ingredientes

Durante o resfriamento e sob agitação lenta adicionar lentamente:

1. Aspartame;

2. Acessulfame $-\mathrm{K}$

3. Polpa de fruta

4. O produto esta pronto para o envase

5. Obs: Ao adicionar os ingredientes utilizar luvas e máscara facial.

\begin{tabular}{|l|l|l|}
\hline ELABORADO POR & VERIFICADO POR & APROVADO POR \\
\hline
\end{tabular}




\begin{tabular}{|c|c|}
\hline $\begin{array}{c}\text { Logo } \\
\text { da Empresa }\end{array}$ & ANÁLISE DE PERIGOS E PONTOS CRÍTICOS DE CONTROLE \\
\hline
\end{tabular}

\section{REGISTRO DE MONITORAMENTO DE PCC Freqüência: a cada 20 minutos}

PASTEURIZAÇÃO DO LEITE CRU

\begin{tabular}{|c|c|c|c|c|}
\hline Data & Hora & Temp. & Ação Corretiva & Funcionário \\
\hline \multirow{5}{*}{} & & & & \\
\hline & & & & \\
\hline & & & & \\
\cline { 2 - 5 } & & & & \\
\hline & & & & \\
\hline & & & & \\
\hline & & & & \\
\hline & & & & \\
\hline & & & & \\
\hline & & & & \\
\hline & & & & \\
\hline
\end{tabular}

PROCEDIMENTO: realizar a leitura da temperatura de pasteurização no painel de controle a cada 20minutos

AÇÃO CORRETIVA:

Verificar se a válvula de retorno esta funcionando. Em caso negativo interromper a pasteurização e entrar em contato com o responsável pela manutenção.

Temperatura abaixo do padrão: verificar se a pressão da caldeira esta normal. Em caso negativo interromper a pasteurização e entrar em contato com o responsável pela manutenção.

Temperatura acima do padrão: ajustar a temperatura no painel do pasteurizador 


\begin{tabular}{|c|c|}
\hline $\begin{array}{c}\text { Logo } \\
\text { da Empresa }\end{array}$ & ANÁLISE DE PERIGOS E PONTOS CRÍTICOS DE CONTROLE \\
\hline
\end{tabular}

Data _ _ _ _ _ _ REGISTRO DE MONITORAMENTO DE PCC

\begin{tabular}{|c|c|c|c|c|}
\hline \multicolumn{5}{|c|}{$\begin{array}{c}\text { Pasteurização da Mistura } \\
85^{\circ} \mathrm{C} \text { por } 20 \text { minutos ou } 90^{\circ} \mathrm{C} \text { por } 5 \text { minutos }\end{array}$} \\
\hline Leituras & Hora & 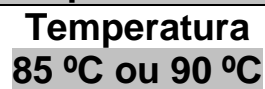 & Ação Corretiva & Funcionário \\
\hline \multicolumn{5}{|l|}{$1^{\mathrm{a}}$} \\
\hline \multicolumn{5}{|l|}{$2^{\mathrm{a}}$} \\
\hline $3^{\mathrm{a}}$ & & & & \\
\hline $\begin{array}{l}\text { PROCEDIN } \\
\text { AÇÃO COP } \\
\text { Reiniciar o } \\
\text { Verificar a p }\end{array}$ & $\begin{array}{l}\text { TO: Pas } \\
\text { TIVA: } \\
\text { cimentc } \\
\text { são da c }\end{array}$ & $\begin{array}{l}\text { zar a mistura de } \\
\text { ustar tempo x ter } \\
\text { ra. }\end{array}$ & temperatura pres & S IT 001 e 002 \\
\hline
\end{tabular}

\begin{tabular}{|c|c|c|c|}
\hline \multicolumn{4}{|c|}{ Fermentação } \\
\hline Hora & $\begin{array}{c}\text { Temp. } \\
38-39 \stackrel{\circ}{ }\end{array}$ & Ação Corretiva & Funcionário \\
\hline & & & \\
\hline & & & \\
\hline & & & \\
\hline \multicolumn{4}{|c|}{$\begin{array}{l}\text { PROCEDIMENTO: Resfriar a massa a } 38^{\circ} \mathrm{C} \text { e manter essa temperatura até atingir o pH ideal. } \\
\text { Realizar leitura da temperatura da massa a cada } 1 \text { hora } \\
\text { AÇ̃̃O CORRETIVA: } \\
\text { Ajustar a temperatura - abrir o registro de vapor }\end{array}$} \\
\hline
\end{tabular}

\begin{tabular}{|c|c|c|c|c|}
\hline \multicolumn{5}{|c|}{ Quebra da Massa } \\
\hline Hora & $\begin{array}{c}\text { pH } \\
\mathbf{4 , 4 - 4 , 6}\end{array}$ & Temp. & \multicolumn{1}{c|}{ Ação Corretiva } & Funcionário \\
\hline & & & & \\
\hline & & & & \\
\hline & & & & \\
\hline & $\begin{array}{l}\text { PROCEDIMENTO: Acompanhar a queda do pH até atingir o valor ideal e iniciar o resfriamento. } \\
\text { AÇÃO CORRETIVA: } \\
\text { pH acima de 4,6: manter a temperatura da massa em 38 }{ }^{\circ} \mathrm{C} \text { e acompanhar a queda do pH até 4,6 } \\
\text { para iniciar o resfriamento } \\
\text { pH abaixo de 4,4: entrar em contato com o Gerente de Garantia da Qualidade }\end{array}$ \\
\hline
\end{tabular}




\begin{tabular}{|c|c|c|c|}
\hline \multirow[t]{2}{*}{$\begin{array}{c}\text { Logo } \\
\text { da Empresa }\end{array}$} & \multirow{2}{*}{\multicolumn{2}{|c|}{$\begin{array}{l}\text { PROCEDIMENTO PADRÃO DE } \\
\text { HIGIENE OPERACIONAL } \\
\text { INSTRUÇÃO DE TRABALHO }\end{array}$}} & $\begin{array}{l}\text { Código: PPHO-010 } \\
\text { Revisão: } 0\end{array}$ \\
\hline & & & Emissão: 08/11/06 \\
\hline LOCAL & \multicolumn{3}{|c|}{ BOTAS / LAVADOR DE BOTAS } \\
\hline RESPONSABILIDADE & \multicolumn{3}{|c|}{ OPERACIONAL LINHA DE PROCESSO } \\
\hline E.P.I. & & & \\
\hline $\begin{array}{l}\text { PRODUTOS } \\
\text { UTILIZADOS }\end{array}$ & \multicolumn{3}{|c|}{ DETERGENTE NEUTRO } \\
\hline CONCENTRAÇÃO & \multicolumn{3}{|l|}{3 a $5 \%$} \\
\hline $\begin{array}{l}\text { PREPARO DA } \\
\text { SOLUÇÃO }\end{array}$ & \multicolumn{3}{|c|}{ OPERADOR DA SEÇÃO } \\
\hline $\begin{array}{l}\text { RESPONSAVEL } \\
\text { PELA SOLUÇÃO }\end{array}$ & \multicolumn{3}{|c|}{ LABORATORIO CONTROLE DE QUALIDADE } \\
\hline TEMPERATURA & \multicolumn{3}{|l|}{ AMBIENTE } \\
\hline TEMPO & \multicolumn{3}{|c|}{ NÄO DETERMINADO } \\
\hline FREQUENCIA & \multicolumn{3}{|c|}{ AO ENTRAR NA ÁREA DE PRODUÇÃO } \\
\hline \multicolumn{4}{|l|}{ PROCEDIMENTO } \\
\hline $\begin{array}{l}\text { 1. Umedecer as b } \\
\text { 2. Mergulhar a es } \\
\text { 3. Esfregar as bot } \\
\text { 4. Enxaguar bem }\end{array}$ & $\begin{array}{l}\text { tas com água; } \\
\text { ovva na solução d } \\
\text { as com a escova e } \\
\text { as botas até a rem }\end{array}$ & $\begin{array}{l}\text { eutr } \\
\text { erfíci } \\
\text { dete }\end{array}$ & \\
\hline ELABORADO POR & VERIFICADO POR & APR & DO POR \\
\hline
\end{tabular}




\section{Check-list para Avaliação das Condições de Higiene e Conduta Pessoal e Instalações Sanitárias Freqüência: mensal}

Data:

Responsável

\begin{tabular}{|l|l|l|l|}
\hline Higiene Pessoal & Sim & Não & Ação corretiva \\
\hline $\begin{array}{l}\text { 1- Os uniformes dos manipuladores estão limpos e em bom } \\
\text { estado de conservação? }\end{array}$ & & & \\
\hline 2- Os calçados são adequados e estão limpos? & & & \\
\hline 3- Os manipuladores estão devidamente barbeados & & & \\
\hline 4- Os manipuladores estão com os cabelos cortados? & & & \\
\hline $\begin{array}{l}\text { 5- Os manipuladores sempre praticam atitudes higiênicas } \\
\text { como: não tossir ou espirrar sobre os alimentos, } \\
\text { equipamento, não levar a mão à boca, nariz e orelhas, não } \\
\text { cuspir no ambiente, etc, evitando contaminação? }\end{array}$ & & & \\
\hline $\begin{array}{l}\text { 6- O manipuladores com curativos nas mãos e braços são } \\
\text { deslocados para serviços que não entrem em contato com } \\
\text { os alimentos? }\end{array}$ & & & \\
\hline $\begin{array}{l}\text { 7- Os manipuladores obedecem às recomendações de } \\
\text { fumar somente nas áreas destinadas a este fim? }\end{array}$ & & & \\
\hline $\begin{array}{l}\text { 8- Os manipuladores cumprem as recomendações de não } \\
\text { se alimentar, mascar chicletes, palitos, etc nas áreas de } \\
\text { trabalho? }\end{array}$ & & & \\
\hline $\begin{array}{l}\text { 9- Os manipuladores lavam mãos e botas antes de entrar } \\
\text { na área de produção? }\end{array}$ & & & \\
\hline Instalações Sanitárias & Sim & Não & Ação corretiva \\
\hline $\begin{array}{l}\text { 10- Os cestos de resíduo possuem tampas, acionamento } \\
\text { por pedal e são abastecidos com sacos plásticos }\end{array}$ & & & \\
diariamente? & & & \\
\hline $\begin{array}{l}\text { 11- Existem cartazes educativos para os manipuladores e } \\
\text { visitantes nas áreas e acesso aos ambientes de } \\
\text { processamento, vestiários e sanitários? }\end{array}$ & & & \\
\hline $\begin{array}{l}\text { 12- As instalações sanitárias e vestiários dos } \\
\text { manipuladores (vasos sanitários, pias, armários) estão em } \\
\text { bom estado de conservação? }\end{array}$ & & & \\
\hline $\begin{array}{l}\text { 13- Há disponibilidade de água, detergentes, sanitizantes e } \\
\text { papel toalha e papel higiênico nos sanitários e vestiários? }\end{array}$ & & & \\
\hline $\begin{array}{l}\text { 14- Há disponibilidade de água, detergentes, sanitizantes e } \\
\text { papel toalha nos lavatórios localizados na entrada da } \\
\text { Usina? }\end{array}$ & & & \\
\hline $\begin{array}{l}\text { 15- A freqüência de reposição de detergentes, sanitizantes } \\
\text { e papel toalha e higiênico é adequada? }\end{array}$ & & & \\
\hline
\end{tabular}




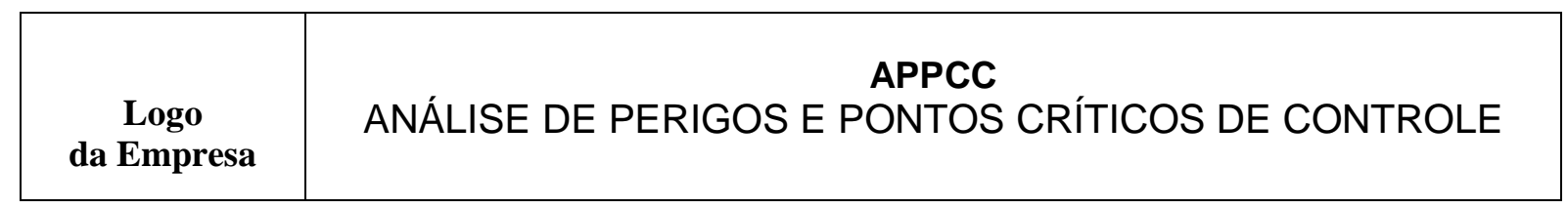

\section{REGISTRO DE MONITORAMENTO DE PCC CONTROLE TEMPERATURA CÂMARA FRIA}

\begin{tabular}{|c|c|c|c|c|c|c|}
\hline \multirow{3}{*}{ Data } & \multirow{3}{*}{ Hora } & \multicolumn{3}{|c|}{ Temperatura } & \multirow{3}{*}{ Ação Corretiva } & \multirow{3}{*}{ Funcionário } \\
\hline & & \multirow{2}{*}{$\begin{array}{l}\text { atual } \\
<6^{\circ} \mathrm{C}\end{array}$} & \multirow{2}{*}{$\begin{array}{l}\max . \\
<6^{\circ} \mathrm{C}\end{array}$} & \multirow{2}{*}{$\frac{\text { min. }}{>0^{\circ} \mathrm{C}}$} & & \\
\hline & & & & & & \\
\hline & 05:00 & & & & & \\
\hline & 11:00 & & & & & \\
\hline & $17: 00$ & & & & & \\
\hline & $23: 00$ & & & & & \\
\hline & 05:00 & & & & & \\
\hline & $11: 00$ & & & & & \\
\hline & $17: 00$ & & & & & \\
\hline & $23: 00$ & & & & & \\
\hline & $05: 00$ & & & & & \\
\hline & 11:00 & & & & & \\
\hline & $17: 00$ & & & & & \\
\hline & $23: 00$ & & & & & \\
\hline & 05:00 & & & & & \\
\hline & 11:00 & & & & & \\
\hline & $17: 00$ & & & & & \\
\hline & $23: 00$ & & & & & \\
\hline & 05:00 & & & & & \\
\hline & $11: 00$ & & & & & \\
\hline & $17: 00$ & & & & & \\
\hline & $23: 00$ & & & & & \\
\hline & 05:00 & & & & & \\
\hline & $11: 00$ & & & & & \\
\hline & $17: 00$ & & & & & \\
\hline & 23:00 & & & & & \\
\hline & 05:00 & & & & & \\
\hline & 11:00 & & & & & \\
\hline & $17: 00$ & & & & & \\
\hline & $23: 00$ & & & & & \\
\hline $\begin{array}{l}\text { PROC } \\
\text { cada } 6 \\
\text { AÇÃO } \\
\text { funcior } \\
\text { contate }\end{array}$ & $\begin{array}{l}\text { DIMEN7 } \\
\text { horas } \\
\text { CORRET } \\
\text { amento } \\
\text { com o r }\end{array}$ & $\begin{array}{l}\text { Realiz } \\
\text { : Cas } \\
\text { quipar } \\
\text { onsáve }\end{array}$ & $\begin{array}{l}\text { leitura } \\
\text { temper } \\
\text { to de fr } \\
\text { ela man }\end{array}$ & $\begin{array}{l}\text { tempe } \\
\text { a atual } \\
\text { nanter } \\
\text { רção. }\end{array}$ & $\begin{array}{l}\text { ls nos horários es } \\
\text { ta acima do padrã câmara fec } \\
\text { tas }\end{array}$ & $\begin{array}{l}\text { cados - a } \\
\text { rificar o } \\
\text { as e entrar em }\end{array}$ \\
\hline
\end{tabular}




\begin{tabular}{|c|c|c|c|}
\hline \multirow[t]{2}{*}{$\begin{array}{c}\text { Logo } \\
\text { da Empresa }\end{array}$} & \multirow{2}{*}{\multicolumn{2}{|c|}{ INSTRUÇÃO DE TRABALHO }} & \begin{tabular}{|l} 
Código: IT-008 \\
Revisão: 0
\end{tabular} \\
\hline & & & Emissão: 06/12/06 \\
\hline OPERAÇÃO & \multicolumn{3}{|c|}{ EXPEDIÇÃO PRODUTO ACABADO } \\
\hline RESPONSABILIDADE & \multicolumn{3}{|c|}{ OPERACIONAL EXPEDIÇÃO } \\
\hline E.P.I. & \multicolumn{3}{|c|}{$\begin{array}{l}\text { CASACO PARA CÂMARA FRIA, LUVAS DE LÃ, CAPUZ DE } \\
\text { LÃ, BOTAS }\end{array}$} \\
\hline $\begin{array}{l}\text { TEMPERATURA } \\
\text { FREQUENCIA }\end{array}$ & \multicolumn{3}{|c|}{$0 \mathrm{~A} 6 \circ \mathrm{C}$} \\
\hline \multicolumn{4}{|l|}{ PROCEDIMENTO } \\
\hline \multicolumn{4}{|c|}{$\begin{array}{l}\text { 1. Montar os páletes de acordo com os produtos descritos na "Ordem de } \\
\text { Carregamento"; } \\
\text { 2. Completar a planilha "Ordem de Carregamento" com as informações: } \\
\text { data de fabricação e no do lote, etc; } \\
\text { 3. Dar preferência para os produtos com data de fabricação mais antiga, } \\
\text { seguindo o PEPS - Primeiro que entra, Primeiro que sai; } \\
\text { 4. Verificar as condições internas do baú do veículo, preenchendo a } \\
\text { planilha de "Controle de Expedição"; } \\
\text { 5. As paredes, piso e teto do baú devem estar limpos, sem resíduos de leite } \\
\text { ou qualquer material estranho; } \\
\text { 6. O interior do baú não deve ter odores estranhos que possam contaminar } \\
\text { os produtos; } \\
\text { 7. Estando o baú em condições de higiene adequadas e com o } \\
\text { 8. Tequipamento de frio ligado, iniciar o carregamento; } \\
\text { frio deve permanecer ligado. }\end{array}$} \\
\hline ELABORADO POR & VERIFICADO POR & APR & O POR \\
\hline
\end{tabular}




\begin{tabular}{|c|c|}
\hline $\begin{array}{c}\text { Logo } \\
\text { da Empresa }\end{array}$ & APPCC \\
ANÁLISE DE PERIGOS E PONTOS CRÍTICOS DE \\
CONTROLE
\end{tabular}

REGISTRO DE MONITORAMENTO DE PCC Freqüência: a cada caminhão carregado

CONTROLE DE EXPEDIÇÃO PRODUTO ACABADO

\begin{tabular}{|c|c|c|c|c|}
\hline \multicolumn{5}{|l|}{ Data: } \\
\hline \multicolumn{5}{|c|}{ Placa do Veículo: } \\
\hline \multicolumn{5}{|l|}{ Motorista: } \\
\hline \multicolumn{3}{|c|}{ Inicio carregamento: ___ hs } & \multicolumn{2}{|c|}{ Final carregamento: $\_$hs } \\
\hline \multicolumn{5}{|c|}{ AVALIAÇẤO DO BAÚ } \\
\hline & APROVADO & REPROVADO & AÇĀO CORRETIVA & FUNCIONARIO \\
\hline \multicolumn{5}{|l|}{$\begin{array}{c}\text { Limpeza } \\
\text { geral }\end{array}$} \\
\hline \multicolumn{5}{|l|}{$\begin{array}{l}\text { Odor } \\
\text { estranho }\end{array}$} \\
\hline $\begin{array}{l}\text { Equipamento } \\
\text { de frio ligado }\end{array}$ & & & & \\
\hline
\end{tabular}

PROCEDIMENTO: De acordo com IT 008 (Expedição Produto Acabado), avaliar as condições internas do baú e assinalar com um " $x$ " nos itens aprovado ou reprovado.

AÇÃO CORRETIVA: Caso o veículo seja reprovado em algum dos itens analisados, não iniciar o carregamento até que as falhas sejam corrigidas. 


\begin{tabular}{|c|c|c|c|}
\hline \multirow{3}{*}{$\begin{array}{l}\text { Logo } \\
\text { da Empresa }\end{array}$} & \multirow{3}{*}{\multicolumn{2}{|c|}{$\begin{array}{l}\text { PROCEDIMENTO PADRÃO DE } \\
\text { HIGIENE OPERACIONAL } \\
\text { INSTRUÇÃO DE TRABALHO }\end{array}$}} & \multirow{3}{*}{\begin{tabular}{|l|} 
Código: PPHO-012 \\
Revisão: 0 \\
Emissão: 08/11/06
\end{tabular}} \\
\hline & & & \\
\hline & & & \\
\hline EQUIPAMENTO & \multicolumn{3}{|c|}{ TANQUE ISOTÉRMICO RODOVIÁRIO } \\
\hline $\begin{array}{l}\text { RESPONSABILIDADE } \\
\text { E.P.I. }\end{array}$ & \multicolumn{3}{|c|}{$\begin{array}{c}\text { LABORATORIO CONTROLE DE QUALIDADE } \\
\text { LUVAS DE BORRACHA, AVENTAL PLASTICO, ÓCULOS }\end{array}$} \\
\hline $\begin{array}{l}\text { PRODUTO } \\
\text { UTILIZADO }\end{array}$ & $\begin{array}{l}\text { DETERGENTE } \\
\text { NEUTRO }\end{array}$ & $\begin{array}{l}\text { DETERGENTE } \\
\text { ALCALINO }\end{array}$ & SANITIZANTE \\
\hline CONCENTRAÇÃO & 3 A $5 \%$ & 1,25 A $1,5 \%$ & 0,15 A $0,2 \%$ \\
\hline $\begin{array}{l}\text { PREPARO DA } \\
\text { SOLUÇÃO }\end{array}$ & \multicolumn{3}{|c|}{ FUNCIONARIO DA PLATAFORMA } \\
\hline $\begin{array}{l}\text { RESPONSAVEL PELA } \\
\text { SOLUÇÃO }\end{array}$ & \multicolumn{3}{|c|}{ LABORATORIO CONTROLE DE QUALIDADE } \\
\hline TEMPERATURA & AMBIENTE & $80^{\circ} \mathrm{C}$ & AMBIENTE \\
\hline TEMPO & 15 MINUTOS & 15 MINUTOS & \\
\hline FREQUENCIA & \multicolumn{3}{|c|}{ APÓS O ESVAZIAMENTO } \\
\hline \multicolumn{4}{|c|}{$\begin{array}{l}\text { PROCEDIMENTO } \\
\text { 1. O funcionário deve subir na carreta levando um balde com solução de } \\
\text { detergente neutro e uma bucha de nylon para limpeza da borracha de } \\
\text { vedação da boca do tanque e do varão da válvula de saída; } \\
\text { 2. Engatar a mangueira da central CIP na saída do tanque e a mangueira de } \\
\text { recalque no spray ball; } \\
\text { 3. Pré enxágüe: fazer o enxágüe do tanque com água a temperatura ambiente } \\
\text { até retirar todo o resíduo de leite; } \\
\text { 4. Fechar o registro de entrada de água e abrir o registro do tanque de solução } \\
\text { alcalina permitindo a circulação da mesma; } \\
\text { 5. Coletar amostra da solução no retorno para análise da concentração de } \\
\text { detergente alcalino; } \\
\text { 6. Proceder a correção da concentração de detergente para } 1,25 \% \text {; } \\
\text { 7. Aquecer a solução com vapor até atingir } 85 \text { oc e deixar circular por } 15 \\
\text { minutos; } \\
\text { 8. Fazer enxágüe com água a temperatura ambiente até que todo o resíduo de } \\
\text { detergente seja eliminado; recolocar a borracha de vedação na tampa do } \\
\text { tanque; } \\
\text { 9. Sanitização: pulverizar as partes internas do tanque com uma solução } \\
\text { sanitizante a concentração de } 0,2 \% \text {. }\end{array}$} \\
\hline ELABORADO POR & VERIFICADO & & ROVADO POR \\
\hline
\end{tabular}




\begin{tabular}{|c|c|}
\hline $\begin{array}{c}\text { Logo } \\
\text { da Empresa }\end{array}$ & APPCC \\
\hline
\end{tabular}

\section{REGISTRO DE MONITORAMENTO DE PCC Freqüência: após a utilização do equipamento}

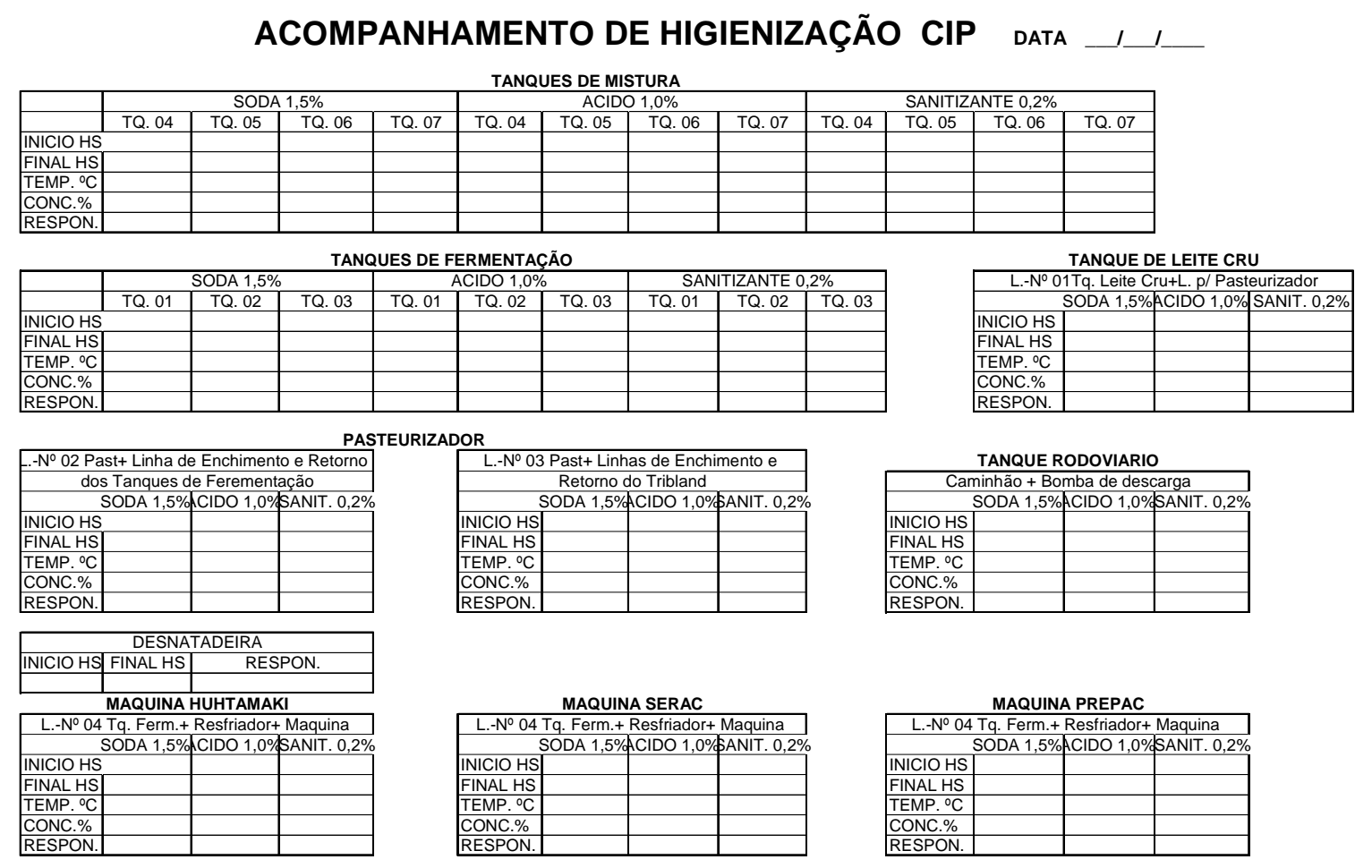

